\title{
Geochemical, textural, mineralogical and micropaleontological data used for climatic reconstruction during the Holocene in the Galician sector of the Iberian continental margin
}

\section{Reconstruccción climática durante el Holoceno en el sector gallego del margen continental ibérico: Datos geoquímicos, texturales, mineralógicos y micropaleontológicos}

\author{
V. Martins ${ }^{1}$ \\ F. Rocha ${ }^{1}$ \\ C. Gomes ${ }^{1 *}$ \\ V. Gomes ${ }^{1}$ \\ J. Jouanneau ${ }^{2}$ \\ O. Weber ${ }^{2}$ \\ J. Dias ${ }^{3}$ \\ ${ }^{1}$ Departamento de Geociências \\ Universidade de Aveiro \\ Campus de Santiago \\ 3810-193 Aveiro, Portugal \\ *E-mail: cgomes@geo.ua.pt \\ ${ }^{2}$ Département de Géologie et d'Océanographie \\ Université de Bordeaux I/CNRS \\ France, UMR-CNRS 5805 \\ ${ }^{3}$ Universidade de Algarve, UCTRA \\ Campus de Gambelas \\ 8000 Faro, Portugal \\ Recibido en junio de 2003; aceptado en abril de 2004
}

\begin{abstract}
In the present study, $\mathrm{Al}, \mathrm{Ca}, \mathrm{Cd}, \mathrm{Co}, \mathrm{Cr}, \mathrm{Cu}, \mathrm{Fe}, \mathrm{Mg}, \mathrm{Mn}, \mathrm{Ni}, \mathrm{Pb}$ and $\mathrm{Cd}$ concentrations were determined in the sediments of the KSGX 40 core collected from the Galicia muddy patch (NW Iberian continental shelf). The results were integrated together with textural, mineralogical and micropaleontological (foraminifera) data in order to determine the possible climatic influence on the type of sedimentation that took place in the muddy patch. The geochemical data of the KSGX 40 core suggest that sediment composition and texture were significantly influenced, over the last $5.2 \mathrm{kyr}$, by the Holocene sea transgression and by climatic oscillations consisting of both relatively temperate/cold periods and relatively warm/wet periods.
\end{abstract}

Key words: geochemical data, marine sediments, climatic oscillations, Holocene, Galicia.

\section{Resumen}

En el presente estudio se han determinado las concentraciones de $\mathrm{Al}, \mathrm{Ca}, \mathrm{Cd}, \mathrm{Co}, \mathrm{Cr}, \mathrm{Cu}, \mathrm{Fe}, \mathrm{Mg}, \mathrm{Mn}, \mathrm{Ni}, \mathrm{Pb}$ y $\mathrm{Cd}$ en un sondeo de sedimento recogido en el depósito lodoso de Galicia (NW de la plataforma continental ibérica). Estos resultados se han comparado con datos texturales mineralógicos y micropaleontológicos (foraminíferos) para estudiar la influencia climática en la sedimentación de este depósito lodoso. Los datos geoquímicos del sondeo KSGX 40 sugieren que la composición de los sedimentos y su tamaño de grano han estado influenciados durante los últimos 5.2 ka por la transgresión holocénica del nivel del mar y por oscilaciones climáticas que consisten tanto de periodos relativamente templados/fríos como de periodos cálidos/ lluviosos.

Palabras clave: datos geoquímicos, oscilaciones climáticas, Holoceno, sedimentos, depósito lodoso de Galicia. 


\section{Introduction}

In this work we present and analyze data from the Ocean Margin Exchange (OMEX) core KSGX 40, collected in the Galicia muddy patch (NW Iberian continental shelf) (fig. 1).

The OMEX project aims to gain a better understanding of the physical, chemical, biological and sedimentological processes that occur at the ocean margin of the European continental shelf in order to quantify energy and matter fluxes across this boundary.

The main features of the NW Iberian continental shelf that define the circulation, transport and deposition of fine sediments were discussed by Jouanneau et al. (1998) and Dias et al. (2002a, b). Araujo et al. (2002) studied the geochemistry of the sediments from both the Galicia and Douro muddy deposits and Oliveira et al. (2002) studied the distribution of clay minerals in the same sediments. The Iberian continental margin is affected by coastal upwelling (Frouin et al., 1990), responsible for the high oceanic productivity in the region.

This area is characterized by a high energy regime where hydrodynamic forces are capable of transporting and reworking sediments as deep as $100 \mathrm{~m}$ (Dias et al. 2002a, b). In the outer continental shelf, the transport ability of oceanic currents is reduced, allowing the sinking of fine particulate matter enriched in heavy metals either of natural or anthropic origin, supplied by the Galician rías and the rivers of northern Portugal. They discharge into the continental shelf, with maximum discharges during winter (Araujo et al., 2002). There is also some atmospheric supply of this elements.

In the present work, the distribution of $\mathrm{Al}, \mathrm{Ca}, \mathrm{Fe}, \mathrm{Mg}, \mathrm{Cu}$, $\mathrm{Pb}, \mathrm{Zn}, \mathrm{Cr}, \mathrm{Co}, \mathrm{Ni}$ and $\mathrm{Cd}$ concentrations in sediments from the KSGX 40 core is discussed and related to textural, mineralogical and micropaleontological (benthic and planktonic foraminifera) data with the aims of checking for a possible climatic change record during sedimentation.

\section{Materials and methods}

The OMEX KSGX 40 core (164 cm long) was collected from the muddy patch $\left(42^{\circ} 14^{\prime} 98^{\prime \prime} \mathrm{N}, 09^{\circ} 01^{\prime} 01^{\prime \prime} \mathrm{W}\right)$ located at the Galician continental shelf off Ría de Vigo (fig. 1), at a sea depth of $115 \mathrm{~m}$.

The grain size analysis was carried out using a Malvern $3600 \mathrm{E}$ laser diffraction particle sizer, which provided the grain size distribution in the $0.05-878 \mu \mathrm{m}$ size range. Calcium carbonate content was determined by a gasometric method.

To reduce the effects of sediment variable grain size, only the fine fractions $(<63 \mu \mathrm{m})$ were analyzed. These fractions were obtained by wet sieving and dried at $60^{\circ} \mathrm{C}$. Chemical element concentrations in the sediment samples studied were determined following the method proposed by Lecomte and Sondag (1980): $1 \mathrm{~g}$ of sediment was digested with a mixture of $3 \mathrm{~mL}$ of $\mathrm{HCl}(37 \%), 2 \mathrm{~mL}$ of $\mathrm{HNO}_{3}(65 \%)$ and $1 \mathrm{~mL}$ of $\mathrm{HF}$ (40\%). After drying at $120^{\circ} \mathrm{C}$, the residue was mixed with $10 \mathrm{~mL}$ of $\mathrm{HNO}_{3}$. The resulting solution was centrifuged,

\section{Introducción}

En el presente trabajo se presentan y analizan datos del sondeo KSGX 40 del proyecto Ocean Margin Exchange (OMEX), recolectado de un depósito lodoso en Galicia (NW de la plataforma continental ibérica) (fig. 1).

El objetivo del proyecto OMEX es entender mejor los procesos físicos, químicos, biológicos y sedimentológicos que ocurren en el margen oceánico de la plataforma continental europea, para poder cuantificar los flujos de energía y materia a través de este confín.

Las principales características del NW de la plataforma continental ibérica que definen la circulación, el transporte y el depósito de sedimentos finos han sido descritos por Jouanneau et al. (1998) y Dias et al. (2002a, b). Araujo et al. (2002) estudiaron la geoquímica de los sedimentos de los depósitos lodosos de Galicia y Douro, y Oliveira et al. (2002) estudiaron la distribución de minerales arcillosos en estos mismos sedimentos. El margen continental ibérico está influenciado por surgencias costeras (Frouin et al., 1990), responsables de la alta productividad oceánica de la región.

Esta zona se caracteriza por un régimen de alta energía, en el que las fuerzas hidrodinámicas pueden transportar y

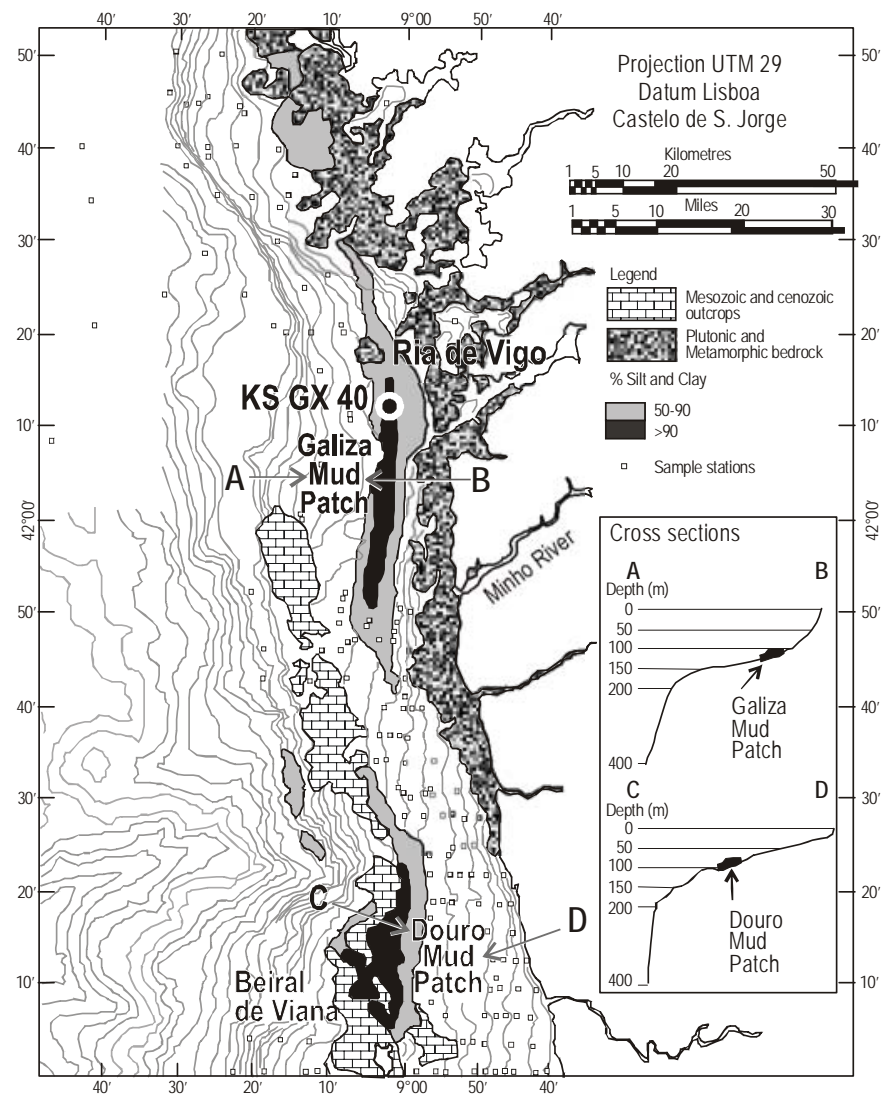

Figure 1. Location of OMEX core KSGX 40 (adapted from Dias et al., 2002a).

Figura 1. Localización del sondeo KSGX 40 de OMEX (adaptado de Dias et al., 2002a). 
filtered and mixed with demineralized water. Determinations of $\mathrm{Al}, \mathrm{Ca}, \mathrm{Cd}, \mathrm{Co}, \mathrm{Cr}, \mathrm{Cu}, \mathrm{Fe}, \mathrm{Mg}, \mathrm{Mn}, \mathrm{Ni}, \mathrm{Pb}$ and $\mathrm{Zn}$ were carried out by flame atomic absorption spectrometry on a GBC 600 spectrophotometer.

Mineralogical studies were conducted on the $<2 \mu \mathrm{m}$ sediment size fraction using $\mathrm{X}$-ray diffraction techniques. The clay fraction $(<2 \mu \mathrm{m})$ was obtained by conventional sedimentation techniques, according to Stokes' Law. Qualitative and semiquantitative mineralogical analyses of the clay fractions followed the criteria recommended by Schultz (1964), Barahona (1974), Thorez (1976), Mellinger (1979) and Pevear and Mumpton (1989).

Biostratigraphic and palaeoecological studies based on benthic foraminifera and the assessment of the relative contents of terrigenous and biogenic components were carried out using a binocular on the $>63 \mu \mathrm{m}$ sediment fraction of samples collected every centimeter along the core. We determined the evolution of the total abundance of endofaunal species characteristic of the inner and middle shelf (less than $50 \mathrm{~m}$ depth), which are markers of both high organic matter contents and low oxygen contents, as well as that of suspension feeders associated with temperate/cold waters. Also, species diversity was assessed using the Shannon-Wiener index (according to Shannon, 1948):

$$
H_{(s)}=-\sum_{n i=1}^{s} p i \ln p i
$$

where $H$ is the information function, $p i$ is the proportion of species and $S$ the number of species. The total density of foraminifera (number of shells per gram of sediment) and the density of autochthonous benthic foraminifera (deposited in situ, without evidence of transport) were also determined.

For ${ }^{14} \mathrm{C}$ dating using AMS (accelerator mass spectrometry), 10-20 mg of foraminifera shells were separated from the sediment fractions $>125 \mu \mathrm{m}$ corresponding to the sediment layers of 39-40 cm, 69-70 cm and 134-135 cm, in the laboratory of Beta Analytic Inc., Miami, Florida (USA).

The data obtained were subjected to multivariate statistical analysis (principal components analysis and Pearson correlations) using the Statistica (v. 5.1) software.

\section{Results}

Carbon-14 dating provided ages for three sediment layers (table 1). The intercalated ages were estimated on the basis of these values. Core KSGX 40 contains sediments that were deposited during the last 5200 years BP.

The KSGX 40 core consists, from the base to the top, of a sedimentary sequence exhibiting gradual upward decrease of grain size (fig. 2). In the upper section of the core, approximately from the depth of $100 \mathrm{~cm}$ upwards, the fine fraction of sediment $<63$ (silt + clay) is abundant (60-90\%), whereas the retrabajar los sedimentos hasta profundidades de $100 \mathrm{~m}$ (Dias et al. 2002a, b). En la plataforma continental exterior la capacidad de transporte de las corrientes oceánicas disminuye, lo que permite el hundimiento de la materia particulada fina enriquecida con metales pesados de origen tanto natural como antropogénico, aportados por las rías de Galicia y los ríos del norte de Portugal. Éstos descargan en la plataforma continental, con máxima descarga en invierno (Araujo et al., 2002). También hay aporte atmosférico de estos elementos.

En este estudio se discute la distribución de las concentraciones de $\mathrm{Al}, \mathrm{Ca}, \mathrm{Fe}, \mathrm{Mg}, \mathrm{Cu}, \mathrm{Pb}, \mathrm{Zn}, \mathrm{Cr}, \mathrm{Co}$, Ni y Cd en sedimentos del sondeo KSGX 40 y se relaciona con datos texturales, mineralógicos y micropaleontológicos (foraminíferos bentónicos y planctónicos) con el propósito de determinar un posible registro del cambio climático durante la sedimentación.

\section{Materiales y métodos}

El sondeo KSGX 40 de OMEX (164 cm de largo) fue recolectado de un depósito lodoso $\left(42^{\circ} 14^{\prime} 98^{\prime \prime} \mathrm{N}, 09^{\circ} 01^{\prime} 01^{\prime \prime} \mathrm{W}\right.$ ) localizado en la plataforma continental de Galicia frente a la Ría de Vigo (fig. 1), a una profundidad del mar de $115 \mathrm{~m}$.

Para el análisis del tamaño de grano se utilizó un analizador de tamaño de partícula por difracción láser (Malvern 3600E), el cual proporcionó la distribución del tamaño de grano en el intervalo de 0.05 a $878 \mu \mathrm{m}$. Se determinó el contenido de carbonato de calcio mediante un método gasométrico.

Para reducir los efectos del tamaño variable de los granos de sedimento, sólo se analizaron las fracciones finas $(<63 \mu \mathrm{m})$. Estas fracciones se obtuvieron mediante tamizado en húmedo y se secaron a $60^{\circ} \mathrm{C}$. Las concentraciones de los elementos químicos en las muestras de sedimento estudiadas se determinaron de acuerdo con el método propuesto por Lecomte y Sondag (1980): se digirió $1 \mathrm{~g}$ de sedimento con una mezcla de $3 \mathrm{~mL}$ de $\mathrm{HCl}$ (37\%), $2 \mathrm{~mL}$ de $\mathrm{HNO}_{3}$ (65\%) y $1 \mathrm{~mL}$ de $\mathrm{HF}(40 \%)$; se secó a $120^{\circ} \mathrm{C}$ y el residuo se mezcló con $10 \mathrm{~mL}$ de $\mathrm{HNO}_{3}$. La solución resultante se centrifugó, filtró y mezcló con agua desmineralizada. Se realizaron determinaciones de $\mathrm{Al}, \mathrm{Ca}, \mathrm{Cd}$, $\mathrm{Co}, \mathrm{Cr}, \mathrm{Cu}, \mathrm{Fe}, \mathrm{Mg}, \mathrm{Mn}, \mathrm{Ni}, \mathrm{Pb}$ y Zn mediante espectroscopía de absorción atómica con llama en un espectrofotómetro GBC 600.

Se llevaron a cabo estudios mineralógicos de la fracción de sedimento $<2 \mu \mathrm{m}$ utilizando técnicas de difracción por rayos X. La fracción arcillosa ( $<2 \mu \mathrm{m})$ fue obtenida con técnicas de sedimentación convencionales, de acuerdo con la ley de Stokes. Los análisis mineralógicos cualitativos y semicuantitativos de las fracciones arcillosas se hicieron utilizando los criterios recomendados por Schultz (1964), Barahona (1974), Thorez (1976), Mellinger (1979) y Pevear y Mumpton (1989).

Se realizaron estudios bioestratigráficos y paleoecológicos basados en foraminíferos bentónicos, así como la evaluación de los contenidos relativos de componentes terrígenos y biogénicos, usando un binocular, de la fracción de sedimento $>63 \mu \mathrm{m}$ de muestras recolectadas cada centímetro a lo largo del sondeo. Se determinó la evolución de la abundancia total de las especies endofaunales características de la plataforma interna y 
Table 1. Radiocarbon ages (using accelerator mass spectrometry, AMS).

Tabla 1. Edades determinadas mediante datación por ${ }^{14} \mathrm{C}$ (usando espectrometría acelerada de masa).

\begin{tabular}{cccc}
\hline Level & $\begin{array}{c}\text { Measured } \\
\text { radiocarbon age }\end{array}$ & $\begin{array}{c}\text { Conventional } \\
\text { radiocarbon age }\end{array}$ & 2 Sigma calibrated age \\
\hline $39-40 \mathrm{~cm}$ & $1.110 \pm 40 \mathrm{BP}$ & $1.500 \pm 40 \mathrm{BP}$ & $\begin{array}{c}\text { Cal AD } 800 \text { to } 1000 \\
\text { Cal BP 1.114 to } 950(=1045 \pm 95)\end{array}$ \\
$69-70 \mathrm{~cm}$ & $2.270 \pm 40 \mathrm{BP}$ & $2.680 \pm 40 \mathrm{BP}$ & $\begin{array}{c}\text { Cal BC } 510 \text { to } 350 \\
\text { Cal BP 2.460 to } 2.300(2380 \pm 80)\end{array}$ \\
$134-135 \mathrm{~cm}$ & $3.820 \pm 40 \mathrm{BP}$ & $4.250 \pm 40 \mathrm{BP}$ & $\begin{array}{c}\text { Cal BC } 2.490 \text { to } 2.290 \\
\text { Cal BP 4.440 to } 4.240(4340 \pm 100)\end{array}$ \\
\hline
\end{tabular}

sand fraction $(>63 \mu \mathrm{m})$ becomes more abundant in the lower section of the core (fig. 2).

The relative abundance of non-cohesive sediment particles presents values $>65 \%$ in the $33-55 \mathrm{~cm}$ sections and below $76 \mathrm{~cm}$ (fig. 2). The $\mathrm{CaCO}_{3}$ content ranges from $2 \%$ to $18 \%$ of the dry sediment weight and is higher in the lower section of the core (fig. 2). Foraminifera and mollusc shells are important sediment biogenic components, significantly contributing to the total sediment $\mathrm{CaCO}_{3}$.

Illite $(50-75 \%)$ is the predominant clay mineral, followed by kaolinite (16-18\%), smectite (0-15\%) and chlorite (2$10 \%)$. Illite and kaolinite, as well as chlorite and smectite, vary in an opposite way along the core studied (fig. 3).

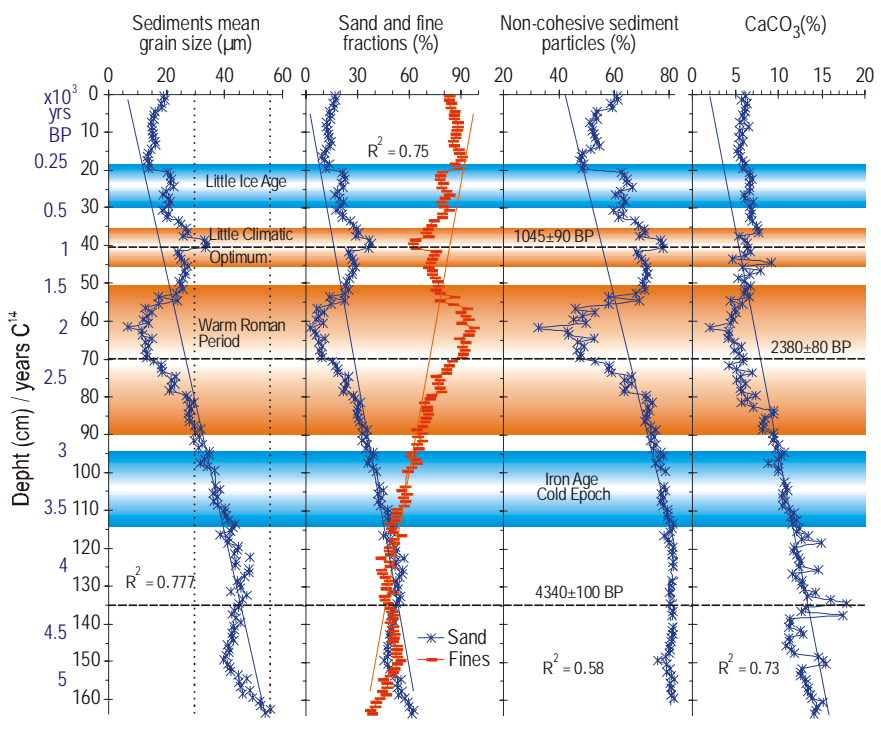

Figure 2. Vertical evolution of sediment mean grain size, sediment silt and sand fractions, non-cohesive particles and $\mathrm{CaCO}_{3}$ content. In these logs, the means, the moving average of values, the trend line and the ages corresponding to the ${ }^{14} \mathrm{C}$ dated sedimentary layers are also represented.

Figura 2. Evolución vertical del tamaño de grano, de la fracción de limo y de arena, de las partículas no cohesivas y del contenido de $\mathrm{CaCO}_{3}$ del sedimento. En estos registros también se muestran los valores medios, las medias móviles, la línea de tendencia y las edades de las capas de sedimentos determinadas mediante datación por ${ }^{14} \mathrm{C}$. media ( $<50 \mathrm{~m}$ de profundidad) que indican tanto contenidos altos de materia orgánica como bajos de oxígeno, así como la de especies suspensívoras asociadas con aguas templadas/frías. Asimismo, se evaluó la diversidad de especies con el índice de Shannon-Wiener (según Shannon, 1948):

$$
H_{(s)}=-\sum_{n i=1}^{s} p i \ln p i
$$

donde $H$ es la función de información, pi es la proporción de especies y $S$ es el número de especies. También se determinaron la densidad total de foraminíferos (número de conchas por gramo de sedimento) y la densidad de foraminíferos bentónicos autóctonos (depositados in situ, sin evidencias de transporte).

Para la datación por ${ }^{14} \mathrm{C}$ (utilizando espectrometría acelerada de masa), en el laboratorio de Beta Analytic Inc. en Miami, Florida (EUA), se separaron 10-20 mg de conchas de foraminíferos de las fracciones de sedimento $>125 \mu \mathrm{m}$ correspondientes a las siguientes capas de sedimento: $39-40 \mathrm{~cm}$, 69-70 cm y 134-135 cm.

Los datos obtenidos fueron sometidos a análisis estadístico multivariante (análisis de componentes principales y correlaciones de Pearson) usando la paquetería Statistica (v. 5.1).

\section{Resultados}

La datación mediante ${ }^{14} \mathrm{C}$ arrojó edades para tres niveles de sedimento (tabla 1). Se estimaron las edades intercaladas sobre la base de estos valores. El sondeo KSGX 40 contiene sedimentos que fueron depositados durante los últimos 5200 años AP.

El sondeo KSGX 40 consiste, de la base a la parte superior, de una secuencia sedimentaria que disminuye gradualmente de tamaño de grano hacia arriba (fig. 2). En la parte superior del sondeo, aproximadamente de $100 \mathrm{~cm}$ de profundidad hacia arriba, la fracción de sedimento fino $<63 \mu \mathrm{m}$ (limo + arcilla) es abundante (60-90\%), mientras que la fracción de arena (>63 $\mu \mathrm{m}$ ) es más abundante en la parte inferior del sondeo (fig. 2). 


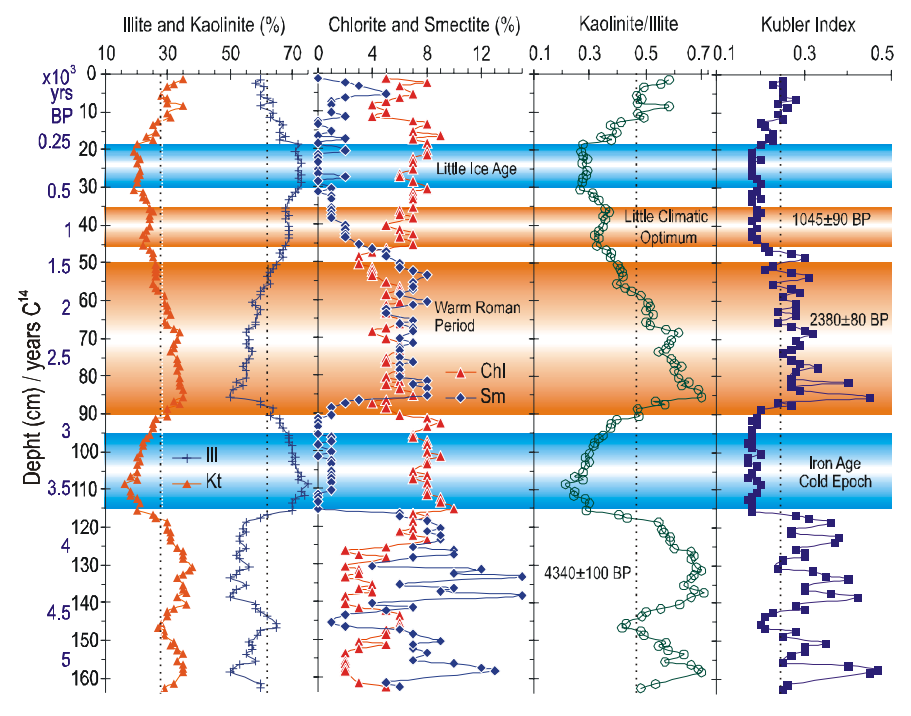

Figure 3. Vertical evolution of the clay mineral content, kaolinite/ilite ratio and Kubler index of illite crystallinity. Sediment layers dated by ${ }^{14} \mathrm{C}$ are marked.

Figura 3. Evolución vertical del contenido de mineral arcilloso, de la razón caolinita/ilita y del índice de Kubler de cristalinidad de la ilita. Se indican las capas de sedimento fechadas mediante ${ }^{14} \mathrm{C}$.

The values of the Kubler index of illite crystallinity (Kubler, 1964; Segonzac, 1969) and the kaolinite/illite ratio are higher in two particular sections of the core, between 164 and $120 \mathrm{~cm}$, and between 85 and $45 \mathrm{~cm}$, and show a tendency to increase between 20 and $0 \mathrm{~cm}$ (fig. 3).

In the 164-115 cm section, higher contents of kaolinite and smectite occur. In the 115-95 cm section, the abundance of these clay minerals decreases, but illite and chlorite contents increase. In the 90-50 cm section, smectite content increases and kaolinite content shows the highest values despite the reduction of kaolinite content starting at $85 \mathrm{~cm}$ (fig. 3). In the sediments of the upper $50 \mathrm{~cm}$ of the core, chlorite persists in higher contents whereas smectite is absent or rare. Between 18 and $30 \mathrm{~cm}$, the kaolinite/illite ratio decreases notably (fig. 3).

Pyrite is always present along the core, both in the sand fractions as framboidal sedimentary deposits and in pyritized shells of benthic foraminifera.

Benthic foraminifera assemblages along core KSGX 40 consist of autochthonous individuals (not showing transport marks) and of transported shells (broken or abraded).

The total number of foraminifera (benthic and planktonic) shells per gram of sediment is, as a rule, higher below the depth of $80 \mathrm{~cm}$ down to the basis of the core $(<6500$ shells per gram of sediment), this section also being characterized by a higher number of autochthonous benthic foraminifera and transported shells (fig. 4).

Some species of the benthic foraminifera assemblages found in core KSGX 40 are better represented in the inner and/ or middle shelf environments of this North Atlantic region. Such is the case of Ammonia beccarii, Asterigerinata mamila,
La abundancia relativa de partículas granulares no cohesivas muestra valores $>65 \%$ en la sección de 33 a $55 \mathrm{~cm}$ y debajo de $76 \mathrm{~cm}$ (fig. 2). El contenido de $\mathrm{CaCO}_{3}$ varía de $2 \%$ a $18 \%$ del peso de sedimento seco y es mayor en la sección inferior del sondeo (fig. 2). Las conchas de foraminíferos y moluscos son importantes componentes biogénicos de estos sedimento y contribuyen significativamente al $\mathrm{CaCO}_{3}$ total.

La ilita (50-75\%) es el mineral arcilloso predominante, seguida por la caolinita (16-18\%), la esmectita (0-15\%) y la clorita (2-10\%). La ilita y la caolinita, así como la clorita y la esmectita, varían de forma opuesta en el sondeo estudiado (fig. 3).

Los valores del índice de Kubler de cristalinidad de la ilita (Kubler, 1964; Segonzac, 1969) y la razón caolinita/ilita son mayores en dos secciones particulares del sondeo, entre $164 \mathrm{y}$ $120 \mathrm{~cm}$ y entre 85 y $45 \mathrm{~cm}$, y muestran una tendencia a incrementar entre 20 y $0 \mathrm{~cm}$ (fig. 3).

En la sección de 164 a $115 \mathrm{~cm}$ se encuentran contenidos mayores de caolinita y esmectita. En la sección de 115 a 95 cm, decrece la abundancia de estos minerales arcillosos, pero aumentan los contenidos de ilita y clorita. En la sección de 90 a $50 \mathrm{~cm}$ el contenido de esmectita se incrementa y el contenido de caolinita muestra sus valores más altos a pesar de que el contenido de este mineral se empieza a reducir a los $85 \mathrm{~cm}$ (fig. 3). En los sedimentos de los $50 \mathrm{~cm}$ superiores del sondeo persisten los elevados contenidos de clorita mientras que la esmectita es escasa o está ausente. Entre los 18 y $30 \mathrm{~cm}$ la razón caolinita/ilita decrece notablemente (fig. 3).

La pirita siempre está presente a lo largo del sondeo, tanto en las fracción de area en la forma de depósitos sedimentarios framboidales como en conchas piritizadas de foraminíferos bentónicos.

Las asociaciones de foraminíferos bentónicos en el sondeo KSGX 40 están formadas por individuos autóctonos (sin señales de transporte) y por conchas transportadas (rotas o gastadas).

El número total de conchas de foraminíferos (bentónicos y planctónicos) por gramo de sedimento es, en general, mayor por debajo de la profundidad de $80 \mathrm{~cm}$ hasta la base del sondeo ( $<6500$ conchas por gramo de sedimento), caracterizándose esta sección por un mayor número de foraminíferos bentónicos autóctonos y de conchas transportadas (fig. 4).

Algunas especies de las asociaciones de foraminíferos bentónicos están mejor representadas en los ambientes de la plataforma interna y/o media de esta región del Atlántico Norte. Tal es el caso de Ammonia beccarii, Asterigerinata mamila, Bolivina pseudoplicata, Cibicides ungerianus, Cribrononion gerthi, Discorbis mira, D. williamsoni, Eggerelloides scaber, Elphidium complanatum, E. crispum, E. discoidale, E. macellum var. aculeatum, E. pulvereum, Haynesina depressula, Lepidodeuterammina ochracea, Planorbulina mediterranensis, Quinqueloculina seminulum y Remaneica helgolandica (Pujos, 1976; Blanc-Vernet et al., 
Bolivina pseudoplicata, Cibicides ungerianus, Cribrononion gerthi, Discorbis mira, D. williamsoni, Eggerelloides scaber, Elphidium complanatum, E. crispum, E. discoidale, E. macellum var. aculeatum, E. pulvereum, Haynesina depressula, Lepidodeuterammina ochracea, Planorbulina mediterranensis, Quinqueloculina seminulum and Remaneica helgolandica (Pujos, 1976; Blanc-Vernet et al., 1984; Cearreta, 1986, 1989, 1994; Mathieu, 1986; Murray, 1991; Alve and Murray, 1994; Banner et al., 1994; Levy et al., 1995; Martins and Carapito, 1999; Mendes et al., 2004).

Hence, the number of foraminifera shells increases in the bottom section of core KSGX 40, where the sediment grain size increases, as does the number of species transported from both the inner and middle shelf and the diversity of benthic foraminifera species, expressed by the Shannon-Wiener index (fig. 4).

The Shannon-Wiener index values (or diversity of benthic foraminifera) decrease in the upper $70 \mathrm{~cm}$ of the core, i.e., in the last $2380 \pm 100$ years cal BP (fig. 4).

Throughout the core, the thanatocoenosis of benthic foraminifera is mainly composed of infaunal species (fig. 5), such as Bolivina dilatata, B. ordinaria, B. pseudoplicata, B. skagerrakensis, Brizalina spathulata, Bulimina exilis,

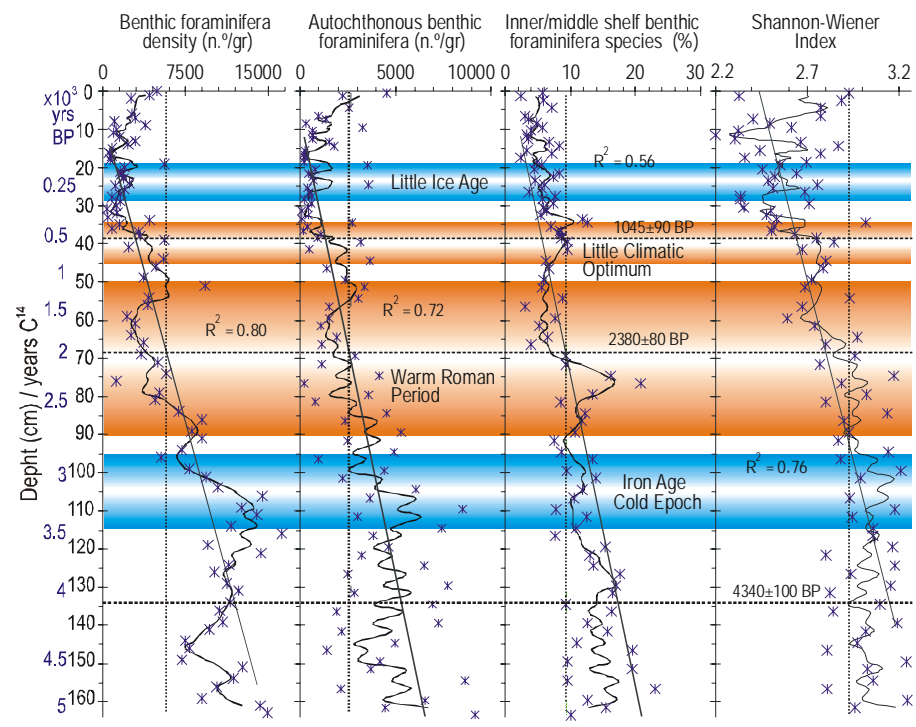

Figure 4. Vertical evolution of total foraminifera density, density of benthic autochthonous foraminifera, total relative abundance of species from the inner and middle shelf, and total relative abundance of suspension feeders, determined along the KSGX 40 core; and Shannon-Wiener Index values, representing the diversity of benthic foraminifera. In these logs, the means, the moving average values, the trend line and the ${ }^{14} \mathrm{C}$ dated sedimentary layers are also represented.

Figura 4. Evolución vertical de la densidad total de foraminíferos, de la densidad de foraminíferos autóctonos bentónicos, de la abundancia relativa total de especies de la plataforma interna y media, y de la abundancia relativa total de especies suspensívoras, determinadas a lo largo del sondeo KSGX 40; y valores del índice de Shannon-Wiener, que representan la diversidad de foraminíferos bentónicos. En estos registros también se muestran las medias, los promedios móviles, la tendencia y las edades de las capas de sedimento fechadas mediante ${ }^{14} \mathrm{C}$.
1984; Cearreta, 1986, 1989, 1994; Mathieu, 1986; Murray, 1991; Alve y Murray, 1994; Banner et al., 1994; Levy et al., 1995; Martins y Carapito, 1999; Mendes et al., 2004).

Por tanto, el número de conchas de foraminíferos aumenta en la sección inferior del sondeo KSGX 40, donde el tamaño de grano aumenta, al igual que el número de especies transportadas desde la plataforma interna y media, y la diversidad de especies de foraminíferos bentónicos, según lo expresa el índice de Shannon-Wiener (fig. 4).

Los valores del índice de Shannon-Wiener (o la diversidad de foraminíferos bentónicos) disminuyen en los $70 \mathrm{~cm}$ superiores del sondeo, i.e., en los pasados $2380 \pm 100$ años cal AP (fig. 4).

A lo largo de todo el sondeo, la tanatocenosis de foraminíferos bentónicos se compone principalmente de especies infaunales (fig. 5) tales como Bolivina dilatata, B. ordinaria, B. pseudoplicata, B. skagerrakensis, Brizalina spathulata, Bulimina exilis, Buliminella tenuata, Chilostomella oolina, C. ovoidea, Fursenkoina loeblichi, F. pauciloculata, Globobulimina spp., Nonionella bradyi, $N$. iridea, N. stella, N. turgida, Sphaeroidina bulloides, Stainforthia complanata, S. feylingi, S. fusiformis y Uvigerina peregrine (Corliss y

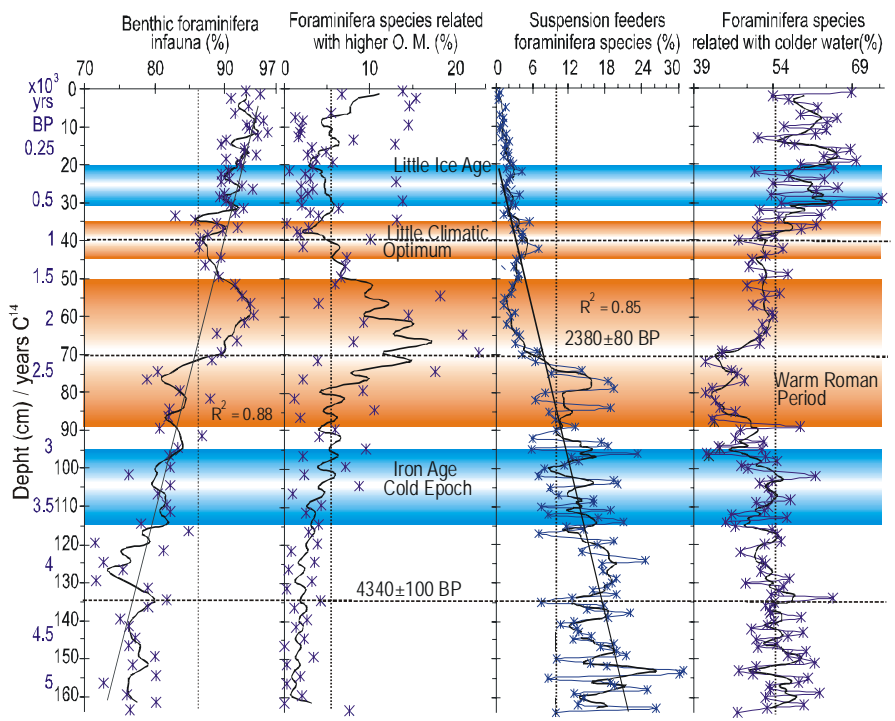

Figure 5. Vertical evolution of the total relative abundance of benthic foraminifera infauna, of species related to the highest organic matter content and lowest oxygen content in sediment, suspension-feeding benthic foraminifera species, and colder water species of outer neritic and bathyal environments. In these logs, the means, the moving average values, the trend line and the values of ${ }^{14} \mathrm{C}$ dating for some particular sediment layers are also represented.

Figura 5. Evolución vertical de la abundancia relativa total de la infauna de foraminíferos bentónicos, de las especies relacionadas con el mayor contenido de materia orgánica y el menor contenido de oxígeno en el sedimento, y de las especies suspensívoras de foraminíferos bentónicos y especies de aguas frías en ambientes batiales y neríticos exteriores. En estos registros también se muestran las medias, los promedios móviles, la tendencia y los valores de la datación por ${ }^{14} \mathrm{C}$ de algunas capas de sedimento en particular. 
Buliminella tenuata, Chilostomella oolina, C. ovoidea, Fursenkoina loeblichi, F. pauciloculata, Globobulimina spp., Nonionella bradyi, $N$. iridea, $N$. stella, $N$. turgida, Sphaeroidina bulloides, Stainforthia complanata, S. feylingi, S. fusiformis and Uvigerina peregrine (Corliss and Emerson, 1990; Corliss, 1991; Buzas et al., 1993; Rathburn and Corliss, 1994; Alve and Murray, 1995; Bernhard and Sen Gupta, 1999; Ernst, 2002).

The relative abundance of infaunal specimens increases from the base to the top of the core, but particularly from the $100-\mathrm{cm}$ level up to the top of the core (fig. 5).

The total relative abundance of species like Ammonia beccarii, Buliminella tenuata, Chilostomella oolina, C. ovoidea, Eggerelloides scaber, Fursenkoina loeblichi, F. pauciloculata, Globobulimina spp., Nonionella stella, N. turgida, Stainforthia complanata, S. feylingi and S. fusiformis, with higher tolerance to significant oxygen depletion in pore water, shows either dysoxic or microxic environments due to high availability of organic matter in the sediment (Mullineaux and Lohmann, 1981; van der Zwaan and Jörissen, 1991; Sen Gupta and Machain-Castillo, 1993; Moodley et al., 1997, 1998; Bernhard and Sen Gupta, 1999; van der Zwaan et al., 1999; Rijk et al., 1999; Ernst, 2002). This group of benthic foraminifera shows higher values in the core section of 90-50 cm (fig. 5), where the relative abundance of sediment fine fraction is higher (fig. 2). In the lower section of the core, the percentage of passive suspension feeders such as Cibicides refulgens, C. ungerianus, Discorbis mira, D. williamsoni, Discorbis spp., Dyocibicides bisserialis, Gavelinopsis praegeri, Hanzawaia nitidula, Lobatula lobatula, Paumotua terebra and Planorbulina mediterranensis, is higher (Murray, 1991; Vergnaud-Grazzini et al., 1989) (fig. 5).

Also present in the assemblages of core KSGX 40 is another group of benthic foraminifera, such as Amphicoryna scalaris, Bigenerina nodosaria, Bolivina albatrossi, $B$. difformis, B. dilatata, B. striatula, B. seminuda, B. robusta, B. skagerrakensis, Brizalina pacifica, B. spathulata, Bulimina exilis, B. aculeate, B. alazanensis, B. marginata, Cassidulina laevigata var. carinata, C. teretis, Cassidulinoides bradyi, Chilostomella oolina, Eggerella bradyi, Globocassidulina subglobosa, Hoeglundina elegans, Hyalinea balthica, Melonis barleeanum, M. pompilioides, Neolenticulina peregrina, Nonionella bradii, Sphaeroidina bulloides, Trifarina angulosa, Uvigerina peregrina and Valvulineria bradyana; however it is generally better represented in temperate/cold waters of outer neritic and bathyal environments (Pujos, 1976; Blanc-Vernet et al., 1984; Cearreta, 1986, 1989, 1994; Mathieu, 1986; Murray, 1991; Alve and Murray, 1994; Banner et al., 1994; Levy et al., 1995; Martins and Carapito, 1999; Mendes et al., in press). The total abundance of this group of benthic foraminifera is lower in the 90-50 cm core section and higher in the 115-95 cm and 30-18 cm core sections (fig. 5).

The chemical data determined are shown in figures 6, 7 and 8. All samples have $\mathrm{Cd}$ concentrations below the detection limit $\left(0.05 \mathrm{mg} \mathrm{kg}^{-1}\right)$.
Emerson, 1990; Corliss, 1991; Buzas et al., 1993; Rathburn y Corliss, 1994; Alve y Murray, 1995; Bernhard y Sen Gupta, 1999; Ernst, 2002).

La abundancia relativa de especímenes infaunales aumenta de la base a la parte superior del sondeo, pero en particular a partir del nivel de $100 \mathrm{~cm}$ hacia arriba (fig. 5).

La abundancia relativa total de especies como Ammonia beccarii, Buliminella tenuata, Chilostomella oolina, C. ovoidea, Eggerelloides scaber, Fursenkoina loeblichi, F. pauciloculata, Globobulimina spp., Nonionella stella, N. turgida, Stainforthia complanata, S. feylingi y S. fusiformis, que muestran mayor tolerancia a una reducción significativa del contenido de oxígeno en el agua intersticial, indica ambientes ya sea disóxicos o micróxicos, debido al elevado contenido de materia orgánica en el sedimento (Mullineaux y Lohmann, 1981; van der Zwaan y Jörissen, 1991; Sen Gupta y MachainCastillo, 1993; Moodley et al., 1997, 1998; Bernhard y Sen Gupta, 1999; van der Zwaan et al., 1999; Rijk et al., 1999; Ernst, 2002). Este grupo de foraminíferos bentónicos tiene mayor presencia en la sección del sondeo de 90 a $50 \mathrm{~cm}$ (fig. 5), donde la abundancia relativa de la fracción fina de los sedimentos es mayor (fig. 2). En la sección inferior del sondeo es mayor el porcentaje de suspensívoros pasivos (fig. 5) como Cibicides refulgens, C. ungerianus, Discorbis mira, D. williamsoni, Discorbis spp., Dyocibicides bisserialis, Gavelinopsis praegeri, Hanzawaia nitidula, Lobatula lobatula, Paumotua terebra y Planorbulina mediterranensis (Murray, 1991; Vergnaud-Grazzini et al., 1989).

En las asociaciones del sondeo KSGX 40 también se encuentra otro grupo de foraminíferos bentónicos, tales como Amphicoryna scalaris, Bigenerina nodosaria, Bolivina albatrossi, B. difformis, B. dilatata, B. striatula, B. seminuda, B. robusta, $B$. skagerrakensis, Brizalina pacifica, $B$. spathulata, Bulimina exilis, B. aculeate, B. alazanensis, B. marginata, Cassidulina laevigata var. carinata, C. teretis, Cassidulinoides bradyi, Chilostomella oolina, Eggerella bradyi, Globocassidulina subglobosa, Hoeglundina elegans, Hyalinea balthica, Melonis barleeanum, M. pompilioides, Neolenticulina peregrina, Nonionella bradii, Sphaeroidina bulloides, Trifarina angulosa, Uvigerina peregrina y Valvulineria bradyana; sin embargo, éste generalmente está mejor representado en aguas templadas/frías de ambientes neríticos y batiales más oceánicos (Pujos, 1976; Blanc-Vernet et al., 1984; Cearreta, 1986, 1989, 1994; Mathieu, 1986; Murray, 1991; Alve y Murray, 1994; Banner et al., 1994; Levy et al., 1995; Martins y Carapito, 1999; Mendes et al., en prensa). La abundancia total de este grupo de foraminíferos bentónicos es menor en la sección del sondeo de 90 a $50 \mathrm{~cm}$ y mayor en las de 115 a $95 \mathrm{~cm}$ y 30 a $18 \mathrm{~cm}$ (fig. 5).

En las figuras 6, 7 y 8 se presentan los datos químicos determinados. Todas las muestras tienen concentraciones de Cd menores que el límite de detección (0.05 mg kg-1).

El análisis de los registros que se presentan en las figuras 6 , 7 y 8 permitió definir dos zonas principales en el sondeo con 


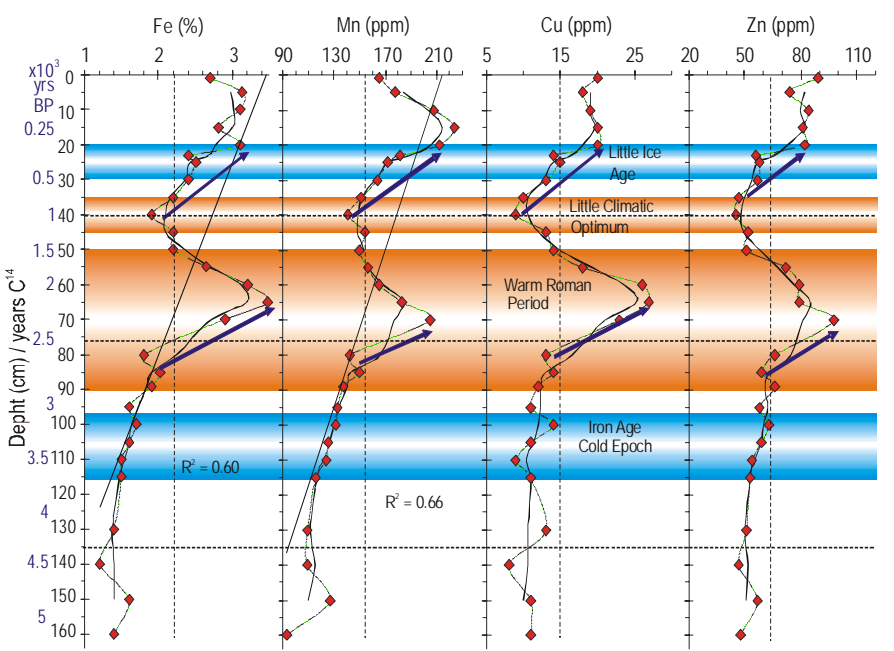

Figure 6. Vertical evolution, along the KSGX 40 core, of $\mathrm{Fe}, \mathrm{Mn}, \mathrm{Cu}, \mathrm{Zn}$, $\mathrm{Co}, \mathrm{Cr}$ and $\mathrm{Pb}$ concentrations. In these logs, the mean and the moving average values of the chemical element contents as well as the ${ }^{14} \mathrm{C}$ dated sedimentary layers are also represented.

Figura 6. Evolución vertical, en el sondeo KSGX 40, de las concentraciones de $\mathrm{Fe}, \mathrm{Mn}, \mathrm{Cu}, \mathrm{Zn}, \mathrm{Cr}$ y $\mathrm{Pb}$. En estos registros también se muestran los valores medios y los promedios móviles de los contenidos de los elementos químicos, así como las capas de sedimentos determinadas mediante datación por ${ }^{14} \mathrm{C}$.

The analysis of the logs shown in figures 6,7 and 8 allowed the definition of two main zones in the core in relation to the distribution of the chemical element concentration values: zone 1, above the $80 \mathrm{~cm}$ level, is characterized by higher (than below this level) concentrations of $\mathrm{Fe}, \mathrm{Mn}$ and $\mathrm{Co}$, and two concentration maxima for $\mathrm{Fe}, \mathrm{Mn}, \mathrm{Zn}, \mathrm{Co}, \mathrm{Cu}, \mathrm{Cr}$ and $\mathrm{Pb}$ identified approximately at $80-50 \mathrm{~cm}$ and $20-0 \mathrm{~cm}$; zone 2, below the $80 \mathrm{~cm}$ level, is characterized by higher $\mathrm{Ca}, \mathrm{Mg}$ and Al concentrations that decrease at $80-50 \mathrm{~cm}$ and $20-0 \mathrm{~cm}$, where the elements referred to in zone 1 show higher concentrations.

The values of Ca concentration decrease, as a rule, from the base to the top of the core, whereas Fe, Mn and Co concentrations show an opposite trend.

Spearman's correlations between chemical element concentrations and textural, mineralogical and micropaleontological parameters subjected to principal components analysis (fig. 9), allowed the definition of the following groups of parameters:

- Group 1, associated with the sediment sand fraction (>63 $\mu \mathrm{m}$ ), comprises the following parameters: $\mathrm{Ca}$ and $\mathrm{CaCO}_{3}$ contents, foraminifera density and total number of suspension feeders. These parameters show significant positive correlations between them, whereas significant negative correlations were found with the parameters of group 2.

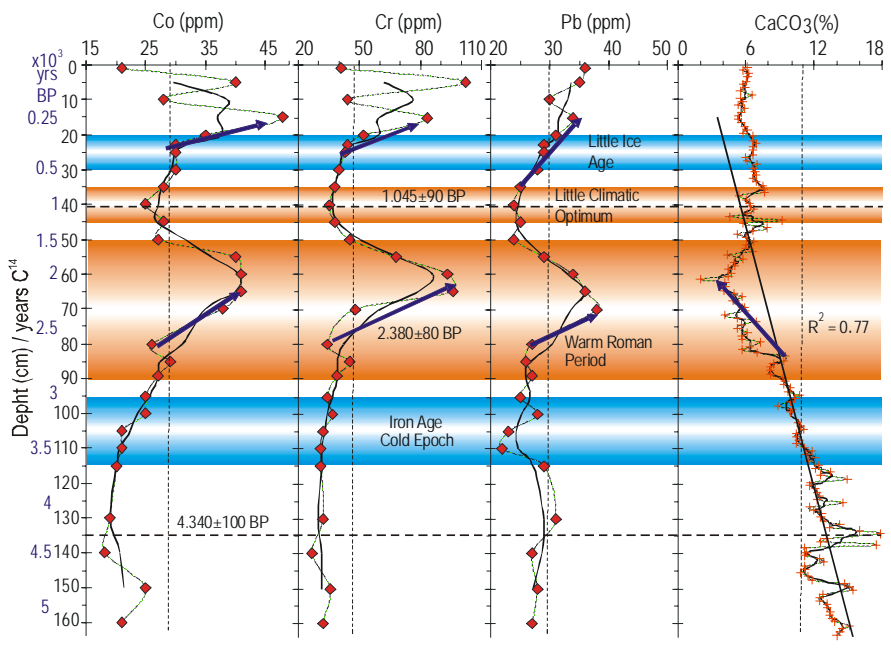

Figure 7. Vertical evolution, along the KSGX 40 core, of the $\mathrm{Co}, \mathrm{Cr}, \mathrm{Pb}$ and $\mathrm{CaCO}_{3}$ concentrations. In these logs, the mean and the moving average values of the chemical element contents as well as the ${ }^{14} \mathrm{C}$ dated sedimentary layers are also represented.

Figura 7. Evolución vertical en el sondeo KSGX 40, de las concentraciones de $\mathrm{Co}, \mathrm{Cr}, \mathrm{Pb}$ y $\mathrm{CaCO}_{3}$. En estos registros también se muestran los valores medios y los promedios móviles de los contenidos de los elementos químicos, así como las capas de sedimentos fechadas mediante ${ }^{14} \mathrm{C}$.

relación a la distribución de los valores de concentración de los elementos: la zona 1, por arriba del nivel de $80 \mathrm{~cm}$, se caracteriza por concentraciones mayores (que por debajo de este nivel) de $\mathrm{Fe}$, Mn y Co, pudiéndose identificar dos concentraciones máximas para $\mathrm{Fe}, \mathrm{Mn}, \mathrm{Zn}, \mathrm{Co}, \mathrm{Cu}, \mathrm{Cr}$ y $\mathrm{Pb}$ de $80 \mathrm{a}$ $50 \mathrm{~cm}$ y de 20 a $0 \mathrm{~cm}$; la zona 2, por abajo del nivel de $80 \mathrm{~cm}$, se caracteriza por concentraciones mayores de $\mathrm{Ca}, \mathrm{Mg}$ y $\mathrm{Al}$ que disminuyen de 80 a $50 \mathrm{~cm}$ y de 20 a $0 \mathrm{~cm}$, donde los elementos referidos para la zona 1 muestran concentraciones mayores.

Los valores de la concentración de Ca disminuyen, por lo general, de la base hacia la parte superior del sondeo, mientras que las concentraciones de Fe, Mn y Co muestran una tendencia opuesta.

Las correlaciones de Spearman entre las concentraciones de los elementos químicos y los parámetros texturales, mineralógicos y micropaleontológicos a los que se les aplicó el análisis de componentes principales (fig. 9), permitieron definir los siguientes grupos de parámetros:

- El grupo 1, asociado con la fracción de sedimento arenoso (>63 $\mu \mathrm{m}$ ), comprende los siguientes parámetros: contenidos de $\mathrm{Ca}$ y $\mathrm{CaCO}_{3}$, densidad de foraminíferos y número total de suspensívoros. Estos parámetros muestran correlaciones positivas significativas entre ellos, mientras que se encontraron correlaciones negativas significativas con los parámetros del grupo 2. 


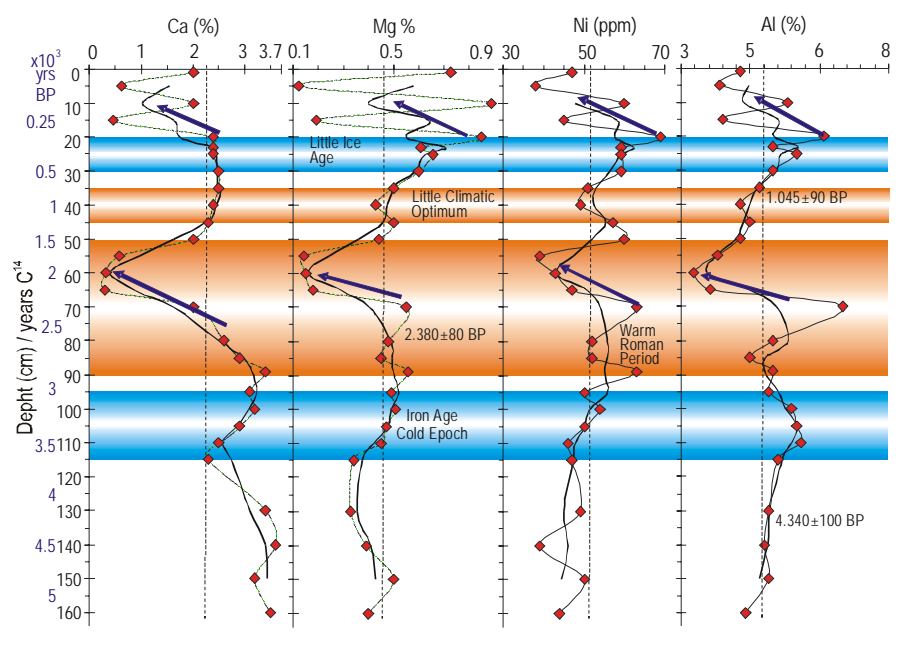

Figure 8. Logs showing the evolution, along the KSGX 40 core, of $\mathrm{Ca}, \mathrm{Mg}$, $\mathrm{Ni}$ and $\mathrm{Al}$ concentrations. In these logs, the mean of values and the moving average values of the chemical element contents as well as the ${ }^{14} \mathrm{C}$ dated sedimentary layers are also represented.

Figura 8. Registros que muestran la evolución, en el sondeo KSGX 40, de las concentraciones de $\mathrm{Ca}, \mathrm{Mg}, \mathrm{Ni}$ y $\mathrm{Al}$. En estos registros también se muestran los valores medios y los promedios móviles de los contenidos de los elementos químicos, así como las capas fechadas mediante ${ }^{14} \mathrm{C}$.

- Group 2, associated with sediment fine fractions (<63 and $<15 \mu \mathrm{m}$ ), comprises the following parameters: $\mathrm{Fe}, \mathrm{Mn}, \mathrm{Cu}$, $\mathrm{Zn}, \mathrm{Pb}, \mathrm{Co}$ and $\mathrm{Cr}$ concentrations. These concentrations exhibit significant positive correlations with the endofauna of benthic foraminifera and with the total number of species related to high organic matter and low oxygen contents.

- Group 3, associated with the clay minerals chlorite and illite and with benthic foraminifera characteristic of cold waters, comprises the following parameters: $\mathrm{Al}, \mathrm{Ni}$ and $\mathrm{Mg}$ concentrations, which show significant positive correlations between them.

- Group 4, associated with the clay minerals kaolinite and smectite, consists of parameters considered markers of relatively warm and wet climates that prevail in the source areas of clay mineral genesis.

Principal components analysis (fig. 9) allows the distinction of two main factors important for the definition of the groups identified. Altogether, factors 1 and 2 explain $71 \%$ of the variance of the data used; these factors are shown in table 2. Factor 1 represents the distribution of the parameters of groups 1 and 2, whereas factor 2 is related to the parameters of groups 3 and 4.

Factor 1 seems to be associated with sediment texture. On the one hand, heavy metal concentrations in the sediments increase as the fine fraction and organic matter contents increase and oxygen content decreases. On the other hand, coarse sediments deposited under more energetic

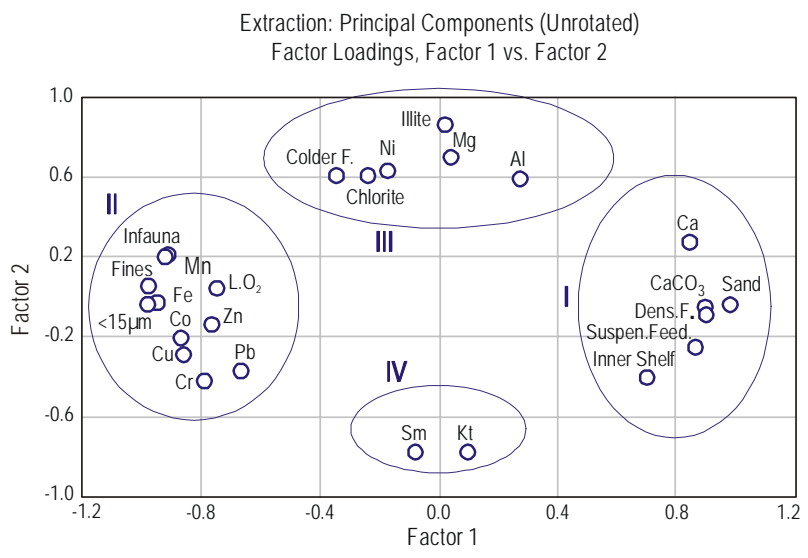

Figure 9. Principal components factor loadings: factor 1 vs 2. L. $\mathrm{O}_{2}=$ benthic foraminifera related to the highest organic matter and the lowest $\mathrm{O}_{2}$ in sediments; ColderF. $=$ species related to colder water; Suspend.Feed. $=$ suspension feeders; Inner Shelf = species from the inner and middle shelf; Cold $=$ cold water species; Carb. $=\mathrm{CaCO}_{3} ;$ Dens.F. $=$ density of foraminifera; $\mathrm{SM}=$ smectite; $\mathrm{Kt}=$ kaolinite.

Figura 9. Cargas factoriales de los componentes principales: factor 1 vs 2. L. $\mathrm{O}_{2}=$ foraminíferos bentónicos relacionados con los mayores contenidos de materia orgánica y los menores de $\mathrm{O}_{2}$ en sedimentos; ColderF. = especies relacionadas con aguas más frías; Suspend.Feed. = especies suspensívoras; Inner Shelf = especies de la plataforma interna y media; Cold = especies de aguas frías; Carb. $=\mathrm{CaCO}_{3}$; Dens.F. $=$ densidad de foraminíferos; $\mathrm{SM}$ = esmectita; $\mathrm{Kt}$ = caolinita.

- El grupo 2, asociado con las fracciones de sedimento fino ( $<63$ y $<15 \mu \mathrm{m})$, comprende los siguientes parámetros: concentraciones de Fe, Mn, $\mathrm{Cu}, \mathrm{Zn}, \mathrm{Pb}$, Co y Cr. Estas concentraciones muestran correlaciones positivas significativas con la endofauna de foraminíferos bentónicos y con el número total de las especies relacionadas con los contenidos altos de material orgánico y bajos de oxígeno.

- El grupo 3, asociado con los minerales arcillosos clorita e ilita y con los foraminíferos bentónicos característicos de aguas frías, comprende los siguientes parámetros: concentraciones de Al, Ni y Mg, los cuales muestran correlaciones positivas significativas entre ellos.

- El grupo 4, asociado con los minerales arcillosos caolinita y esmectita, está formado por parámetros considerados indicadores de climas relativamente templados y lluviosos que prevalecen en las áreas que son fuentes de la génesis de arcilla.

El análisis de componentes principales (fig. 9) permite distinguir dos factores principales importantes para la definición de los grupos identificados. En conjunto, los factores 1 y 2 explican $71 \%$ de la variancia de los datos usados; estos factores se muestran en la tabla 2. El factor 1 representa la distribución de los parámetros de los grupos 1 y 2, mientras que el factor 2 se relaciona con los parámetros de los grupos 3 y 4 .

El factor 1 parece estar asociado con la textura del sedimento. Por un lado, las concentraciones de metales pesados en los sedimentos aumentan conforme la fracción fina y los 
Table 2. Principal components factor loadings (loadings written in bold are $>0.70$ ).

Tabla 2. Cargas factoriales de los componentes principales (las cargas marcadas en negritas son $>0.70$ ).

\begin{tabular}{|c|c|c|}
\hline & Factor 1 & Factor 2 \\
\hline Chlorite & -0.24 & 0.61 \\
\hline Smectite & -0.08 & -0.78 \\
\hline Illite & 0.02 & 0.87 \\
\hline Kaolinite & 0.10 & -0.78 \\
\hline Forams. higher O.M. & -0.73 & 0.05 \\
\hline Suspension feeders & 0.86 & -0.26 \\
\hline Infauna & -0.92 & 0.21 \\
\hline Inner/middle shelf species & 0.70 & -0.40 \\
\hline Colder species & -0.34 & 0.61 \\
\hline $\mathrm{CaCO}_{3}$ & 0.89 & -0.05 \\
\hline Forams. density & 0.90 & -0.09 \\
\hline Sand & 0.98 & -0.04 \\
\hline Fine & -0.98 & 0.06 \\
\hline$<15 \mathrm{~m}$ & -0.95 & -0.03 \\
\hline $\mathrm{Cu}$ & -0.86 & -0.29 \\
\hline $\mathrm{Pb}$ & -0.66 & -0.37 \\
\hline $\mathrm{Ni}$ & -0.17 & 0.63 \\
\hline Co & -0.87 & -0.21 \\
\hline $\mathrm{Fe}$ & -0.98 & -0.04 \\
\hline $\mathrm{Zn}$ & -0.76 & -0.14 \\
\hline $\mathrm{Cr}$ & -0.79 & -0.42 \\
\hline Mn & -0.91 & 0.21 \\
\hline $\mathrm{Mg}$ & 0.04 & 0.70 \\
\hline $\mathrm{Ca}$ & 0.84 & 0.28 \\
\hline $\mathrm{Al}$ & 0.27 & 0.59 \\
\hline Var. (\%) & 52 & 19 \\
\hline
\end{tabular}

hydrodynamic conditions, expressed by higher concentrations of suspension feeding foraminifera, seem to favour the preservation of $\mathrm{CaCO}_{3}$, expressed by higher $\mathrm{Ca}, \mathrm{CaCO}_{3}$ and foraminifera shell contents in the sediments.

Factor 2 is particularly determined by clay mineral assemblages and by their dependence on the weather conditions prevailing at sediment source areas. Chlorite and illite, whose genesis is particularly favoured by cold and dry weather, are included in the same group of benthic foraminifera considered to be markers of cold waters, suggesting that most of the oceanic water cooling episodes occurred because of periods of colder climate. Smectite and kaolinite, whose genesis is particularly favoured by relatively warm and wet climate, are included in group 4. contenidos de materia orgánica auamentan y el contenido de oxígeno disminuye. Por otro lado, los sedimentos de grano grueso depositados en condiciones hidrodinámicas más energéticas evidenciadas por concentraciones mayores de foraminíferos suspensívoros, parecen favorecer la preservación de $\mathrm{CaCO}_{3}$ manifiesta en los mayores contenidos de $\mathrm{Ca}, \mathrm{CaCO}_{3} \mathrm{y}$ conchas de foraminíferos en los sedimentos.

El factor 2 está determinado particularmente por las asociaciones de minerales arcillosos y por su dependencia de las condiciones climáticas prevalecientes en las fuentes de sedimentos. La clorita y la ilita, cuya génesis se ve particularmente favorecida por climas fríos y secos, están incluidas en el mismo grupo de foraminíferos bentónicos considerados indicadores de aguas frías, lo que sugiere que la mayoría de los episodios de enfriamiento oceánico ocurrieron a causa de periodos de clima más frío. La esmectita y la caolinita, cuya génesis es particularmente favorecida por climas templados y lluviosos, están incluidas en el grupo 4.

Las concentraciones de $\mathrm{Ni}, \mathrm{Mg}$ y $\mathrm{Al}$ están incluidas en el grupo 3, relacionado con periodos de clima frío. No es fácil explicar esta asociación; sin embargo, se conoce que el plancton utiliza estos elementos químicos y que la productividad oceánica generalmente es mayor durante episodios fríos. Por ende, es posible que el aumento en la concentración de estos elementos podría estar relacionado con la acumulación de biodetritos como conecuencia de la alta productividad oceánica.

\section{Discusión}

La disminución gradual del tamaño de grano encontrada en el sondeo KSGX 40 probablemente se debe a la transgresión del mar ocurrida durante el Holoceno. Según Zazo et al. (1996), después de la máxima transgresión del Holoceno, alcanzada a los 6900 años AP, sucedió una pequeña caída del nivel del mar seguida por una pequeña elevación del mismo entre 2400 años y el presente.

Algunos cambios climáticos que se presentaron durante el Holoceno parecen haber condicionado el régimen sedimentario marino. Con base en los datos analíticos disponibles fue posible establecer las siguientes zonas en el sondeo KSGX 40.

\section{Zona 1}

La zona 1, que corresponde a la sección de 164 a $90 \mathrm{~cm}$, se caracteriza por: (a) sedimento de tamaño de grano grueso; (b) contenidos mayores de $\mathrm{Ca}, \mathrm{CaCO}_{3}$ y foraminíferos (número de foraminíferos bentónicos y planctónicos por gramo); (c) concentraciones mayores de $\mathrm{Mg}$, $\mathrm{Ni}$ y Al; (d) concentraciones menores de Fe, Mn, $\mathrm{Cu}, \mathrm{Zn}, \mathrm{Co}, \mathrm{Cr}$ y Pb; (e) mayor número de especies de foraminíferos característicos de la plataforma continental interna y media y mayor número de especies suspensívoras; y (f) asociaciones de ilita + caolinita + esmectita + clorita que indican la prevalencia de un clima generalmente templado y frío con oscilaciones intercaladas durante la depositación de sedimento. La ocurrencia de un periodo 
The concentrations of $\mathrm{Ni}, \mathrm{Mg}$ and $\mathrm{Al}$ are included in group 3, which is related to periods of cold climate. It is not easy to explain this association; however, it is known that plankton uses these chemical elements and that oceanic productivity is, as a rule, higher during cold episodes. Therefore, it is possible that the increase of the concentration of these elements could be related to the accumulation of biodetritus as a consequence of high oceanic productivity.

\section{Discussion}

The gradual grain size decrease found in core KSGX 40 could most probably be due to the sea transgression occurred during the Holocene. According to Zazo et al. (1996), after the Holocene transgressive maximum, reached at 6900 years BP, a small drop in the sea level occurred, followed by a small rise in its level between 2400 years and the present.

Some climatic changes that occurred during the Holocene appear to have conditioned the marine sedimentation regime. Based on the analytical data available it was possible to establish three zones in core KSGX 40.

\section{Zone 1}

Zone 1, corresponding to the $164-90 \mathrm{~cm}$ section, is characterized by: (a) coarse grain size sediment; (b) higher $\mathrm{Ca}$, $\mathrm{CaCO}_{3}$ and foraminifera (number of benthic and planktonic foraminifera per gram) contents; (c) higher $\mathrm{Mg}, \mathrm{Ni}$ and $\mathrm{Al}$ concentrations; (d) lower $\mathrm{Fe}, \mathrm{Mn}, \mathrm{Cu}, \mathrm{Zn}, \mathrm{Co}, \mathrm{Cr}$, and $\mathrm{Pb}$ concentrations; (e) higher number of foraminifera species characteristic of the inner and middle continental shelf and higher number of suspension feeders; and (f) illite + kaolinite + smectite + chlorite assemblages indicating a general temperate and wet climate with intercalated oscillations prevailing during sediment deposition. The occurrence of a relatively warm and wet period, corresponding to the core section from the base to the $120-\mathrm{cm}$ level, allowed the input of higher amounts of sediments characterized by coarser grain size into the oceanic system. Together with the terrigenous components, foraminifera were also transported from shallower zones of the shelf. The accumulation of coarse sediments on the outer shelf allowed the easier removal of sediment interstitial water, a fact that favoured the preservation of $\mathrm{CaCO}_{3}$ expressed by the relatively high $\mathrm{Ca}$ content found in sediments and by the fair preservation of foraminifera shells. This rainy period was identified in Europe by Bohncke and Vanderberghe (1991), Zolitschka and Negendank (1993), and Magri (1997).

In the sediment section between 120 and $90 \mathrm{~cm}$, the high content of illite + chlorite indicates the occurrence of relatively cold climatic conditions that prevailed in the continent at the time of the genesis of these clay minerals, 3800-3000 years cal BP. From the base to the top of this section, a decrease in smectite content associated with an increase in chlorite content was recorded in this subsection. Also, a decrease, in this same subsection, of the kaolite/illite ratio, allowed the identification of an episode of cold and dry climate, at least partially relativamente cálido y lluvioso, que en el sondeo corresponde a la sección de la base hasta el nivel de $120 \mathrm{~cm}$, permitió la entrada de mayores cantidades de sedimentos más gruesos al sistema oceánico. Junto con los componentes terrígenos también se transportaron foraminíferos desde las zonas menos profundas de la plataforma. La acumulación de sedimentos gruesos en la plataforma exterior permitió una más fácil remoción del agua intersticial del sedimento, lo que favoreció la preservación de $\mathrm{CaCO}_{3}$ expresada por el contenido relativamente alto de $\mathrm{Ca}$ en los sedimentos y la relativamente buena preservación de las conchas de foraminíferos. Este periodo lluvioso fue indentificado en Europa por Bohncke y Vanderberghe (1991), Zolitschka y Negendank (1993) y Magri (1997).

En la sección de sedimento de 120 a $90 \mathrm{~cm}$, el alto contenido de ilita + clorita indica la presencia de condiciones climáticas relativamente frías que prevalecieron en el continente durante el tiempo de la génesis de estos minerales arcillosos, 3800-3000 años cal AP. De la base a la parte superior de esta sección se registró una disminución en el contenido de esmectita asociado con un aumento en el contenido de clorita. Asimismo, una disminución en esta misma subsección de la razón caolinita/ilita permitió identificar un episodio climático frío y seco, por lo menos parcialmente responsable de la reducción en el aporte de arena al depósito estudiado. Este enfriamiento climático puede estar relacionado con la oscilación térmica conocida como la "Etapa de Lobben", alrededor de 3600 años AP (Ehlers, 1996), que causó la expansión de los glaciares en los Alpes suizos y austriacos.

\section{Zona 2}

La zona 2 corresponde a la sección de 90 a $50 \mathrm{~cm}$ en el sondeo KSGX 40 y se caracteriza por: (a) un rápido aumento en los contenidos de limo $(<63 \mu \mathrm{m})$ y limo fino + arcilla $(<15 \mu \mathrm{m})$; (b) reducción del contenido total de partículas no cohesivas; (c) reducción de los contenidos de $\mathrm{Ca}, \mathrm{Mg}, \mathrm{Ni}, \mathrm{Al}$, $\mathrm{CaCO}_{3}$ y foraminíferos; (d) concentraciones mayores de Fe, $\mathrm{Mn}, \mathrm{Cu}, \mathrm{Zn}, \mathrm{Co}, \mathrm{Cr}$ y P; (e) asociación de ilita + caolinita + clorita + esmectita, en la cual el contenido de esmectita y el índice de cristalinidad de ilita muestran un incremento gradual hacia la parte superior del sondeo, mientras que el contenido de caolinita decrece hacia la parte superior, siendo compensada por el aumento simétrico del contenido de ilita. Las asociaciones de minerales arcillosos mencionadas (disminución del contenido de caolinita y aumento del de esmectita) sugieren la ocurrencia de un periodo climático relativamente más cálido y seco entre 2900 y 1500 años cal AP. Foraminíferos bentónicos de agua templada/fría de ambientes batiales y neríticos externos también indican temperaturas mayores en el fondo oceánico durante este periodo. Esta variación de mejora climática empezó coincidiendo con el principio del Imperio Romano (Crowley y North, 1991), y ha sido mencionada para el área de Galicia por Cortizas et al. (1999, 2000). Un clima más seco y un nivel del mar más alto durante este periodo (mencionados 
responsible for a decrease in sand supply to the deposit studied. This climatic cooling could be related to the thermal oscillation, the "Lobben Stage", around 3600 years BP (Ehlers, 1996) that caused the expansion of the glaciers of the Austrian and Swiss Alps.

\section{Zone 2}

Zone 2 corresponds to the $90-50 \mathrm{~cm}$ section in core KSGX 40 and is characterized by: (a) a rapid increase in silt $(<63 \mu \mathrm{m})$ and fine silt + clay $(<15 \mu \mathrm{m})$ contents; (b) reduction of the total content of non-cohesive particles; (c) reduction of $\mathrm{Ca}, \mathrm{Mg}, \mathrm{Ni}, \mathrm{Al}, \mathrm{CaCO}_{3}$ and foraminifera contents; (d) higher $\mathrm{Fe}, \mathrm{Mn}, \mathrm{Cu}, \mathrm{Zn}, \mathrm{Co}, \mathrm{Cr}$ and $\mathrm{P}$ concentrations; (e) illite + kaolinite + chlorite + smectite assemblage, in which the smectite content and the illite crystallinity index exhibit a gradual increase towards the top of the core, whereas kaolinite content decreases being compensated by the symmetric increase of illite content. The clay mineral assemblages previously mentioned (kaolinite content decrease and smectite content increase), suggest the occurrence of a relatively warmer and dryer climatic period between 2900 and 1500 years cal BP. Temperate/cold water benthic foraminifera from outer neritic and bathyal environments also suggest higher oceanic temperatures on the bottom during this period. This ameliorating climatic oscillation began near the dawn of the Roman Empire (Crowley and North, 1991), and was reported in the Galician area by Cortizas et al. (1999, 2000). A dryer climate and a higher sea level during this period (mentioned by e.g. Fidalgo and Vidal-Romani, 1993; Fidalgo et al., 1993; Pascual et al., 1998) caused a higher deposition of finer sediments and organic matter.

The chemical elements $\mathrm{Fe}, \mathrm{Mn}, \mathrm{Cu}, \mathrm{Pb}, \mathrm{Zn}, \mathrm{Cr}$, $\mathrm{Co}$ and $\mathrm{Ni}$ are usually adsorbed onto sediments, particularly onto clay minerals, due to both their high specific surface area and global negative electric charge. This fact supports the significant positive correlation found between sediment fine silt + clay $(<15 \mu \mathrm{m})$ content and the concentration of these elements.

The main source of $\mathrm{Al}$ is lithogenic. This element participates largely in the structures of both primary and secondary aluminosilicates existing in weathered products, which are introduced into the oceanic system transported mainly by the rivers. However, $\mathrm{Al}$ contents show a weak positive correlation with the sediment fine fraction content and a significant negative correlation with the chemical elements of group 1 . The content of $\mathrm{Al}$ is reduced in this zone of the core, evidencing a decrease in the transport of fine clayey terrigenous sediments that could be compensated by higher deposition of organic matter, mostly transported laterally. Benthic foraminifera assemblages support this assumption, since a higher number of individuals associated with high organic matter content and infaunal species were found in this core section. A high consumption of oxygen by benthic fauna led to an oxygen depletion in sediments. por e.g. Fidalgo y Vidal-Romani, 1993; Fidalgo et al., 1993; Pascual et al., 1998) causaron una mayor depositación de sedimentos más finos y de materia orgánica.

Los elementos químicos $\mathrm{Fe}, \mathrm{Mn}, \mathrm{Cu}, \mathrm{Pb}, \mathrm{Zn}, \mathrm{Cr}$, Co y Ni se adsorben en los sedimentos, particularmente en minerales arcillosos, debido a su gran área superficial específica así como a su carga eléctrica negativa neta. Este hecho apoya la correlación positiva significativa encontrada entre el contenido de limo fino + arcilla $(<15 \mu \mathrm{m})$ y la concentración de los elementos químicos referidos.

La principal fuente de $\mathrm{Al}$ es litogénica. Este elemento participa ampliamente en las estructuras de aluminosilicatos primarias y secundarias que existen en productos intemperizados, los cuales son introducidos al sistema oceánico principalmente por los ríos. Sin embargo, los contenidos de Al muestran una correlación positiva débil con el contenido de la fracción fina y una correlación negativa significativa con los elementos químicos del grupo 1 . El contenido de $\mathrm{Al}$ disminuye en esta zona del sondeo, un hecho que refleja una reducción en el transporte de sedimentos terrígenos finos arcillosos y que pudiera estar compensado por el mayor depósito de materia orgánica, la mayoría transportada lateralmente. Las asociaciones de foraminíferos bentónicos apoyan este supuesto, ya que en esta sección del sondeo se encontró un mayor número de individuos asociados con el contenido de materia orgánica y especies infaunales. Un alto consumo de oxígeno por la fauna béntica resultó en una reducción de oxígeno en los sedimentos.

Las propiedades del sedimento pueden cambiar debido a procesos biológicos, físicos, químicos y diagenéticos (Zuo et al., 1991; Nolting y Helder, 1991). Un ambiente reductor en la interfase agua-sedimento genera las condiciones necesarias para el enriquecimiento diagenético (i.e., que sucede después de la depositación del sedimento) de metales que sufren un cambio de estado redox y se tornan menos solubles, o de metales que forman sulfuros insolubles. En esta zona el comportamiento redox del Fe y Mn puede jugar un papel central en el ciclo de otros metales que pueden ser adsorbidos en precipitados de Fe y Mn.

\section{Zona 3}

La zona 3 corresponde a la sección de 50 a $0 \mathrm{~cm}$ del sondeo KSGX 40 y a un clima similar al actual: Sub-Atlántico (frío y lluvioso). Esta zona comprende dos subzonas.

\section{Subzona 3.1}

La subzona 3.1 corresponde a la sección de 50 a 20 cm y se caracteriza por: (a) un pequeño aumento en la fracción de arena y un pequeño decremento en la fracción $<15 \mu \mathrm{m}$; (b) disminución de la razón caolinita/ilita; (c) aumento del contenido de clorita; (d) aumento en las concentraciones de $\mathrm{Al}, \mathrm{Ca}, \mathrm{Mg}$ y Ni; y (e) reducción de las concentraciones de $\mathrm{Fe}, \mathrm{Mn}, \mathrm{Cu}, \mathrm{Pb}, \mathrm{Zn}$, Cr y Co. 
Biological, physical, chemical and diagenetic processes can change the sediment properties (Zuo et al., 1991; Nolting and Helder, 1991). Reducing conditions at the sediment-water interface create the conditions needed for diagenetic enrichment (i.e. occuring after sediment deposition) of metals that undergo a redox change and become less soluble, or of metals that form insoluble sulphides. In this zone, Fe and Mn redox behaviour could play a central role in the cycling of other metals that can be adsorbed onto Fe and Mn precipitates.

\section{Zone 3}

Zone 3 corresponds to the $50-0 \mathrm{~cm}$ section of core KSGX 40 and to a climate similar to the actual climate: Sub-Atlantic (cold and wet). This zone comprises two sub-zones.

Sub-zone 3.1

Sub-zone 3.1 corresponds to core section $50-20 \mathrm{~cm}$ and is characterized by: (a) a slight increase in the sand fraction and a slight decrease in the $<15 \mu \mathrm{m}$ fraction; (b) decrease of the kaolinite/illite ratio; (c) increase of chlorite content; (d) increase of $\mathrm{Al}, \mathrm{Ca}, \mathrm{Mg}$ and $\mathrm{Ni}$ concentrations; and (e) reduction of $\mathrm{Fe}, \mathrm{Mn}, \mathrm{Cu}, \mathrm{Pb}, \mathrm{Zn}, \mathrm{Cr}$ and $\mathrm{Co}$ concentrations.

The increased $\mathrm{Al}$ content expresses the higher input of fine clayey terrigenous sediments relative to organic matter, justifying both the better preservation of $\mathrm{CaCO}_{3}$ and the higher Ca content values in the sediments. Less deposition of fine particles may have determined the lower contents of $\mathrm{Fe}, \mathrm{Mn}, \mathrm{Cu}$, $\mathrm{Pb}, \mathrm{Zn}, \mathrm{Cr}$ and $\mathrm{Co}$.

The higher illite and chlorite contents, as well as the higher content of benthic foraminifera associated with cold waters, present in the $30-18 \mathrm{~cm}$ core section, could be related to the climatic cooling episode-Little Ice Age, a neo-historical glacial fluctuation (between XVI and XIX centuries, according to Grove, 2001) - that seems to have caused lower sea water temperatures. On the other hand, the $46-35 \mathrm{~cm}$ core section could be related to the warmer episode-Little Climatic Optimumas described by Brown (1998). During these two climatic episodes, dry periods alternating with huge river floods would have occurred, expressed by the slight increase of the sand fraction content and $\mathrm{Al}$ concentration in the sediments.

\section{Sub-zone 3.2}

Sub-zone 3.2 , corresponding to the $20-0 \mathrm{~cm}$ core section, is characterized by: (a) a notable increase of the sediment fine fraction ( $<15 \mu \mathrm{m})$; (b) increased $\mathrm{Fe}, \mathrm{Mn}, \mathrm{Cu}, \mathrm{Pb}, \mathrm{Zn}, \mathrm{Cr}$ and Co concentrations; (c) the increase of the kaolinite/illite ratio; (d) decrease of chlorite content; and (e) decrease of $\mathrm{Al}$, $\mathrm{Ca}, \mathrm{Mg}$ and $\mathrm{Ni}$ concentrations. This section, corresponding to the subrecent period, shows similarities with the 90-50 cm section, with a higher accumulation of finer sediments and organic matter because of a tendency in the sea level to rise and lower hydrodynamics in the area where core KSGX 40 was collected.
$\mathrm{El}$ aumento en el contenido de $\mathrm{Al}$ refleja el mayor aporte de sedimentos terrígenos finos arcillosos con relación a la materia orgánica, justificando tanto la mejor preservación de $\mathrm{CaCO}_{3} \mathrm{y}$ el mayor contenido de Ca en los sedimentos. Un menor depósito de partículas finas pudo haber determinado los contenidos más bajos de $\mathrm{Fe}, \mathrm{Mn}, \mathrm{Cu}, \mathrm{Pb}, \mathrm{Zn}, \mathrm{Cr}$ y Co.

Los contenidos más altos de ilita y clorita, así como de foraminíferos bentónicos asociados con aguas frías, presentes en la sección del sondeo de 30 a $18 \mathrm{~cm}$, pueden estar relacionados con el episodio climático de enfriamiento-Pequeña Edad de Hielo, una fluctuación glacial neohistórica (entre los siglos XVI y XIX, según Grove, 2001)—que aparentemente generó temperaturas menores del agua de mar. Por otro lado, la sección del sondeo de 46 a $35 \mathrm{~cm}$ puede estar relacionada con el episodio más cálido-Pequeño Óptimo Climático—según descrito por Brown (1998). Durante estos dos periodos climáticos, se hubieran presentado periodos secos alternados con gran inundaciones fluviales, lo que se muestra por el pequeño incremento del contenido de la fracción de arena y la concentración de $\mathrm{Al}$ en los sedimentos.

\section{Subzona 3.2}

La subzona 3.2 corresponde a la sección de 20 a $0 \mathrm{~cm}$ del sondeo y se caracteriza por: (a) un incremento significativo de la fracción de sedimento fino $(<15 \mu \mathrm{m})$; (b) concentraciones mayores de $\mathrm{Fe}, \mathrm{Mn}, \mathrm{Cu}, \mathrm{Pb}, \mathrm{Zn}, \mathrm{Cr}$ y Co; (c) aumento de la razón caolinita/ilita; y (e) reducción de las concentraciones de $\mathrm{Al}, \mathrm{Ca}, \mathrm{Mg}$ y Ni. Esta sección, que corresponde al periodo subreciente, muestra similitudes con la sección de 90 a $50 \mathrm{~cm}$, con mayor acumulación de sedimentos finos y materia orgánica por la tendencia al aumento del nivel del mar y menor hidrodinámica del área donde se recolectó el sondeo KSGX 40.

\section{Conclusiones}

La presencia de pirita en el sondeo KSGX 40 indica la ocurrencia de periodos de condiciones anóxicas justo debajo de la interfase agua-sedimento y/o dentro de las conchas de foraminíferos. La pirita es un mineral diagenético común en ambientes anóxicos. Se forma por la reacción del ión sulfato con el hierro en su forma reducida $\left(\mathrm{Fe}^{2+}\right)$. Este proceso es mediado por materia orgánica que llega al fondo y luego es oxidada en una secuencia característica de reacciones (Kaplan et al., 1963).

El origen de $\mathrm{Mn}, \mathrm{Cu}, \mathrm{Co}, \mathrm{Fe}, \mathrm{Zn}, \mathrm{Cr}$ y $\mathrm{Pb}$ en los sedimentos está principalmente relacionado con los aportes de detritos continentales y de rocas intemperizadas.

Tomando en cuenta los datos mineralógicos y geoquímicos determinados, la distribución del tamaño de grano y el contenido total de las especies foraminíferas bentónicas, fue posible establecer la zonografía del sondeo KSGX 40. Tal zonografía indica la ocurrencia de algunas oscilaciones climáticas durante el Holoceno que condicionaron el registro sedimentario del depósito lodoso de la plataforma continental de Galicia. 


\section{Conclusions}

The presence of pyrite in core KSGX 40 indicates the occurrence of periods of anoxic conditions just below the sediment-water interface and/or inside foraminifera shells. Pyrite is a diagenetic mineral common in anoxic environments. It is formed by reaction of the sulphate ion with the reduced form of iron $\left(\mathrm{Fe}^{2+}\right)$. This process is mediated by organic matter reaching the sea floor and then being oxidized in a characteristic sequence of reactions (Kaplan et al., 1963).

The origin of $\mathrm{Mn}, \mathrm{Cu}, \mathrm{Co}, \mathrm{Fe}, \mathrm{Zn}, \mathrm{Cr}$ and $\mathrm{Pb}$ in the sediments is mainly related to detrital inputs from continental soils and weathered rocks.

Taking into account the mineralogical and geochemical data determined, the grain size distribution and the total content of benthic foraminifera species, it was possible to establish the zonography of the KSGX 40 core. Such zonography indicates the occurrence of some climatic oscillations during the Holocene that conditioned the sedimentary record of the Galician continental shelf muddy patch.

Climatic oscillations that occurred during the Holocene and oceanic conditions probably related to small sea level oscillations seem to have conditioned the inflow of these sediment types (texture and composition) into the ocean, as well as its redistribution and deposition.

The trace metal content of the sediments in this zone is a consequence not only of natural weathering but also of local influences, reflecting changes in hydrodynamic conditions and deposition of finer particles and organic carbon in sediments and influencing diagenetic changes.

\section{Acknowledgements}

This research was supported by the Industrial Minerals and Clays Research Center of the Foundation for Science and Technology (FCT) and by the University of Aveiro. This project was partly supported by the European Union within the Marine Science and Technology programme (contract MAS3CT97-0076).

\section{References}

Alve, E. and Murray, J.W. (1994). Ecology and taphonomy of benthic foraminifera in a temperate mesotidal inlet. J. Foraminifer. Res., 24(1): 18-27.

Alve, E. and Murray, J.W. (1995). Benthic foraminiferal distribution and abundance changes in Skagerrak surface sediments: 1937 (Höglund) and 1992/1993 data compared. Mar. Micropalaeontol., 25: 269-288.

Araujo, M.F., Jouanneau, J.M., Valério, P., Barbosa, T., Gouveia, A., Weber, O., Oliveira, A., Rodrigues, A. and Dias, J.M.A. (2002). Geochemical tracers of northern Portuguese estuarine sediments on the shelf. Prog. Oceanogr., 52: 277-297.

Banner, F.T., Knight-Jones, E.W. and Wright, J.M. (1994). Protozoa. In: P.J. Hayward and J.S. Ryland (eds.), The Marine Fauna of the British Isles and North-West Europe. Introduction and Protozoans to Arthropods. Oxford Science Publications, pp. 36-50.
Las variaciones climáticas durante el Holoceno y las condiciones oceánicas probablemente relacionadas con oscilaciones pequeñas del nivel del mar parecen haber condicionado la entrada de estos tipos de sedimento (textura y composición) en el océano, así como su redistribución y depósito.

El contenido de metales traza de los sedimentos en esta zona es resultado no sólo del intemperismo natural sino también de influencias locales, reflejando cambios en las condiciones hidrodinámicas y en el depósito de partículas más finas y carbón orgánico en los sedimentos e influenciando cambios diagenéticos.

\section{Agradecimientos}

Esta investigación se realizó con apoyo del Centro de Investigación de Minerales y Arcillas Industriales de la Fundación para Ciencia y Tecnología (FCT) y de la Universidad de Aveiro. Este proyecto fue parcialmente apoyado por la Unión Europea dentro del programa de tecnología y ciencia marina (contrato MAS3-CT97-0076).

Traducido al español por Christine Harris.

Barahona, E. (1974). Arcillas de ladrillería de la provincia de Granada: Evaluación de algunos ensayos de materias primas. Ph.D. thesis, Granada University, Spain, 398 pp.

Bernhard, J.M and Sen Gupta, B.K. (1999). Foraminifera of oxygendepleted environments. In: B.K. Sen Gupta (ed.), Modern Foraminifera. Kluwer Academic Publishers, pp. 201-216.

Blanc-Vernet, L., Pujos, M. and Rosset Moulinier, M. (1984). Les biocénoses de foraminifères benthiques des plateaux continentaux français (Manche, Sud-Gasconhe, Ouest Provence). Benthos’ 83, 2nd International Symposium Benthic Foraminifera (Pau, April 1983). Pau and Bordeaux, pp. 71-79.

Bohncke, S. and Vanderberghe, J. (1991). Small river basins of SNetherlands. In: L. Starkel, K.J. Gregiory and J.B. Thornes (eds.), Fluvial Processes in the Temperate zone during the last 15.000 years. J. Wiley, pp. 253-281.

Brown, A. (1998). Fluvial evidence of the Medieval warm period and the Late Medieval climate deterioration in Europe. In: G. Benito, V. Baker and K. Gregory (eds.), Palaeohydrology and Environmental Change. John Wiley, pp. 43-52.

Buzas, M.A., Culver, S.J. and Jorissen, F.J. (1993). A statistical evaluation of the microhabitats of living (stained) infaunal benthic foraminifera. Mar. Micropalaeontol., 20: 311-320.

Cearreta, A. (1986). Distribution and ecology of benthic foraminifera in the rias of Santoña and San Vicent de la Barquera (Spain). Ph.D. thesis, University of Exeter, 307 pp.

Cearreta, A. (1989). Foraminiferal assemblages in the Ria of San Vicente de la Barquera (Cantabria, Spain). Rev. Esp. Micropaleontol. Madrid, 12(1): 67-80.

Cearreta, A. (1994). Analisis micropaleontológico e interpretación paleoecológica del relleno sedimentario Holoceno en El Estuario del Bidasoa (Golfo de Bizkaia). Geobios, 27(3): 271-283.

Corliss, B.H. (1991). Morphology and microhabitat preferences of benthic foraminifera from the northwest Atlantic Ocean. Mar. Micropalaeontol., 17: 195-236.

Corliss, B.H. and Emerson, S. (1990). Distribution of Rose Bengal stained deep-sea benthic foraminifera from the Nova Scotian 
continental margin and Gulf of Maine. Deep-Sea Res., 37(3A): 381-400.

Cortizas, A.M., Pontevedra-Pombal, X., García-Rodeja, E., NovoaMuñoz, J.C and Shotyk, W. (1999). Mercury in a Spanish peat bog: Archive of climate change and atmospheric metal deposition. Science, 284: 939-942.

Cortizas, A.M., Pérez-Alberti, A., Franco-Maside, S. and GarcíaRodeja, E. (2000). Evolución del paisaje durante el Holoceno en Galicia (NW de la Península Ibérica). In: F. Díaz del Olmo, D. Faust y A.I. Porras (eds.), Environmental Changes during the Holocene. Commission on the Holocene, Universidad de Sevilla, Katolische Universität Eichstätt and AEQA, Sevilla, pp. 61-64.

Crowley, T.J. and North, G.R. (1991). Paleoclimatology. Oxford Monographs on Geology and Geophysics No. 18, 349 pp.

Dias, J., Jouanneau, J., Gonzalez, R., Araújo, M., Drago, T., Garcia, C., Oliveira, A., Rodrigues, A., Vitorino, J. and Weber, O. (2002a). Present day sedimentary processes on the northern Iberian shelf. Prog. Oceanogr., 52(2-4): 249-259.

Dias, J., Gonzalez, R., Garcia, C. and Diaz-del-Rio, V. (2002b). Sediment distribution patterns on the Galicia-Minho continental shelf. Prog. Oceanogr., 52(2-4): 215-231.

Ehlers, J. (1996). Quaternary and Glacial Geology. John Wiley, 578 pp.

Ernst, S.R. (2002). An experimental study on the proxy value of benthic foraminifera. The impact of physical disturbance, oxygen deplection and organic flux. Geologica Ultraiectina, 220: 157 pp.

Fidalgo, L.S. and Vidal-Romani, J.R. (1993). La transgresión Holocene en la Ría de Ares (a Coruña, Galicia, España). Datos cronológicos, sedimentarios y geomorfológicos. Actas 3a Reunião do Quaternário Ibérico, Universidade de Coimbra, pp. 339-345.

Fidalgo, L.S., Bao-Casal, R. and Jalut, G. (1993). Estudio micropaleontológico de una turbera litoral holocena en la Ría de Ares (A Coruña, Espana). Cuaderno Lab. Xeolóxico de Laxe, 18: 54-66.

Frouin, R., Fiuza, A., Ambar, I. and Boyd, T. (1990). Observations of a poleward surface current off the coast of Portugal and Spain during winter. J. Geophys. Res., 95: 679-691.

Grove, J.M. (2001). The Little Ice Age. Routledge, London and York, $498 \mathrm{pp}$.

Jouanneau, J., Garcia, C., Oliveira, A., Rodrigues, A., Dias, J. and Weber, O. (1998). Dispersal and deposition of suspended sediment on the shelf off the Tagus and Sado estuaries, SW Portugal. Prog. Oceanogr., 42: 233-257.

Kaplan, I.R., Emery, K.O. and Rittenber, S.C. (1963) The distribution and isotopic abundance of sulphur. Recent marine sediments off southern California. Geochim. Cosmochim. Acta, 27: 297-335.

Kubler, B. (1964). Les argiles, indicateurs de métamorphisme. Rev. Inst. Français Pétrole, 19: 1093-1112.

Lecomte, P. and Sondag, F. (1980). Regional geochemical reconnaissance in the Belgian Ardennes, secondary dispersion patterns in stream sediments. Mineralium Deposita, 15(1): 47-60.

Levy, A., Mathieu, R., Poignant, A., Rosset-Moulinier, M., Ubaldo, M.L. and Lebreiro, S. (1995). Foraminiferes actuels de la marge continentale Portuguaise-inventaire et distribution. Memórias do Instituto Geológico e Mineiro, Lisboa, 32: 116 pp.

Magri, D. (1997). Middle and late Holocene vegetaion and climate changes in peninsular Italy. In: H.N. Dalfes, G. Kukia and H. Weiss (eds.), Third Millennium BC Climate Change and Old World Collapse. NATO ASI Ser., 149, Springer-Verlag, pp. 517530.

Martins, M.V. and Carapito, M.C. (1999). Distribuição das comunidades bentónicas de foraminíferos na plataforma continental de Aveiro. Comunicações dos Serviços Geológicos de Portugal, 86: 255-278.
Mathieu, R. (1986). Sediments et foraminiferes actuels et ressurgences cotieres sur la marge continentale Atlantique du Maroc. Revue de Paléobiologie, Benthos '86, Spec. No. 2, pp. 845-850.

Mellinger, R.M. (1979). Quantitative X-ray diffraction analysis of clay minerals. An evaluation. Saskatchewan Research Council, Canada, SRC Report G-79: 1-46.

Mendes, I., Gonzalez, R., Lobo, F., Dias, J.M.A. and Martins, V. (2004). Factors influencing the distribution of recent benthic foraminifera on the Guadiana Shelf (southwestern Iberia). Mar. Micropaleontol., 51: 171-192

Moodley, L., Van der Zwaan, G.J., Herman, P.M.J., Kempers, L. and Van Breugel, P. (1997). Differential response of benthic meiofauna to long-term anoxia with special reference to foraminifera (Protista: Sarcodina). Mar. Ecol. Prog. Ser., 158: 151-163.

Moodley, L., Zwaan, G.L., Rutten, G.M.W. Boom, R.C.E. and Kempers, A.J. (1998). Subsurface activity of benthic foraminifera in relation to porewater oxygen content: Laboratory experiments. Mar. Micropaleontol., 34: 91-106.

Mullineaux, L.S and Lohmann, G.P. (1981). Late Quaternary stagnations and recirculation of the eastern Mediterranean: Changes in the deep water recorded by fossil benthic foraminifera. J. Foraminifer. Res., 11(1): 20-39.

Murray, J.W. (1991). Ecology and Palaeoecology of Benthic Foraminifera. Longman Scientific and Technical, London, 397 pp.

Nolting, R.F. and Helder, W. (1991). Lead and zinc as indicators for atmospheric and riverine particle transport to sediments in the Gulf of Lions. Oceanol. Acta, 14(4): 357-367.

Oliveira, A., Rocha, F., Rodrigues, A., Jouanneau, J., Dias, A., Weber, O. and Gomes, C. (2002). Clay minerals from the sedimentary cover from the northwest Iberian shelf. Prog. Oceanogr., 52(2-4): 233-247.

Pascual, A., Weber, O., Rodriguez-Lazaro, J., Jouanneau, J.M. and Pujos, M. (1998). Le comblement de ria de Gernika (Golfe de Gascogne) à l'Holocène terminal. Oceanol. Acta, 21(2): 263-260.

Pevear, D.R. and Mumpton, D.R. (1989). Quantitative mineral analysis of clays. CMS Workshop Lectures, 1 . The Clay Minerals Society, Colorado (USA).

Pujos, M. (1976). Ecologie des foraminiferes benthiques et des thecamoebiens de la Girond et du plateu continental sudGascogne. Application a la connaissance du Quaternaire terminal de la region ouest-Gironde. Thèse Doctorat d' Ètat ès Sciences, Univ. Bordeaux I, Mémoires de l'Institute de Geologie du Bassin D’Aquitaine, Bordeaux, 8, 274 pp.

Rathburn, A.E. and Corliss, B.H. (1994). The ecology of living (stained) deep-sea benthic foraminifera from the Sulu Sea. Paleoceanography, 9(1): 87-150.

Rijk, S., Troelstra, S.R. and Rohling, E.J. (1999). Benthic foraminiferal distribution in the Mediterranean Sea. J. Foraminifer. Res., 20(2): 93-103.

Schultz, L.G. (1964). Quantitative interpretation of mineralogical composition from X-ray and chemical data for the Pierre Shale. US Geol. Surv. Prof. Paper, 391-C: 1-31.

Segonzac, G.D. (1969). Les minéraux argileux dans la diagenèse. Passage au métamorphisme. Mem. Service Carte Géol. AlsaceLorraine, 29, p. 320.

Sen Gupta, B.K. and Machain-Castillo, M.L. (1993). Benthic foraminifera in oxygen-poor habitats. Mar. Micropalaeontol., 20: 183-201.

Shannon, C.E. (1948). The mathematical theory of communication. Bell System Technical J., 27: 379-423; 623-656.

Thorez, J. (1976). Practical Identification of Clay Minerals. G. Lelotte, Belgique. 
Van der Zwaan, G.J. and Jorissen, F.J. (1991). Biofacial patterns in river-induced shelf anoxia. In: R.V. Tyson and T.H. Pearson (eds.), Modern and Ancient Continental Shelf Anoxia. Geol. Soc. London Spec. Publ., 58: 65-82.

Van der Zwaan G.J., Duijnstee, I.A.P., den Dulk M., Ernst, S.R., Jannink, N.T. and Kouwenhoven, T.J. (1999). Benthic foraminifers: Proxies or problems? A review of paleoecological concepts. Earth Sci. Rev., 46: 213-236.

Vergnaud-Grazzini, C., Caralp, M., Faugères, J.C., Gonthier E., Grousset, F.E., Pujol, C. and Saliège, J.F. (1989). Mediterranean outflow through the Strait of Gibraltar since 18,000 years BP. Oceanol. Acta, 12(4): 305-324.
Zazo, C., Goy, J.L., Lario, J. and Silva, P.G. (1996). Littoral zone and rapid climatic changes during the last 20,000 years. The Iberian study case. Z. Geomorph. NF, Suppl. Bd. 102: 119-134.

Zolitschka, B. and Negendank, J.F.W. (1993). Lago Grande di Monticchio (southern Italy): A high resolution sedimentry record of the last 70,000 years. In: J.F.W. Negendank and B. Zolitschka (eds.), Palaeolimnology of European Maar Lakes. Lecture Notes in Earth Sciences. Springer, Heidelberg, 49, pp. 277-288.

Zuo, Z., Eisma, D. and Berger, G.W. (1991). Determination of sediment accumulation and mixing rates in the Gulf of Lions, the Mediterranean Sea. Oceanol. Acta, 14: 253-262. 


\title{
Geochemical, textural, mineralogical and micropaleontological data used for climatic reconstruction during the Holocene in the Galician sector of the Iberian continental margin
}

\section{Reconstruccción climática durante el Holoceno en el sector gallego del margen continental ibérico: Datos geoquímicos, texturales, mineralógicos y micropaleontológicos}

\author{
V. Martins ${ }^{1}$ \\ F. Rocha ${ }^{1}$ \\ C. Gomes ${ }^{1 *}$ \\ V. Gomes ${ }^{1}$ \\ J. Jouanneau ${ }^{2}$ \\ O. Weber ${ }^{2}$ \\ J. Dias ${ }^{3}$ \\ ${ }^{1}$ Departamento de Geociências \\ Universidade de Aveiro \\ Campus de Santiago \\ 3810-193 Aveiro, Portugal \\ *E-mail: cgomes@geo.ua.pt \\ ${ }^{2}$ Département de Géologie et d'Océanographie \\ Université de Bordeaux I/CNRS \\ France, UMR-CNRS 5805 \\ ${ }^{3}$ Universidade de Algarve, UCTRA \\ Campus de Gambelas \\ 8000 Faro, Portugal \\ Recibido en junio de 2003; aceptado en abril de 2004
}

\begin{abstract}
In the present study, $\mathrm{Al}, \mathrm{Ca}, \mathrm{Cd}, \mathrm{Co}, \mathrm{Cr}, \mathrm{Cu}, \mathrm{Fe}, \mathrm{Mg}, \mathrm{Mn}, \mathrm{Ni}, \mathrm{Pb}$ and $\mathrm{Cd}$ concentrations were determined in the sediments of the KSGX 40 core collected from the Galicia muddy patch (NW Iberian continental shelf). The results were integrated together with textural, mineralogical and micropaleontological (foraminifera) data in order to determine the possible climatic influence on the type of sedimentation that took place in the muddy patch. The geochemical data of the KSGX 40 core suggest that sediment composition and texture were significantly influenced, over the last $5.2 \mathrm{kyr}$, by the Holocene sea transgression and by climatic oscillations consisting of both relatively temperate/cold periods and relatively warm/wet periods.
\end{abstract}

Key words: geochemical data, marine sediments, climatic oscillations, Holocene, Galicia.

\section{Resumen}

En el presente estudio se han determinado las concentraciones de $\mathrm{Al}, \mathrm{Ca}, \mathrm{Cd}, \mathrm{Co}, \mathrm{Cr}, \mathrm{Cu}, \mathrm{Fe}, \mathrm{Mg}, \mathrm{Mn}, \mathrm{Ni}, \mathrm{Pb}$ y $\mathrm{Cd}$ en un sondeo de sedimento recogido en el depósito lodoso de Galicia (NW de la plataforma continental ibérica). Estos resultados se han comparado con datos texturales mineralógicos y micropaleontológicos (foraminíferos) para estudiar la influencia climática en la sedimentación de este depósito lodoso. Los datos geoquímicos del sondeo KSGX 40 sugieren que la composición de los sedimentos y su tamaño de grano han estado influenciados durante los últimos 5.2 ka por la transgresión holocénica del nivel del mar y por oscilaciones climáticas que consisten tanto de periodos relativamente templados/fríos como de periodos cálidos/ lluviosos.

Palabras clave: datos geoquímicos, oscilaciones climáticas, Holoceno, sedimentos, depósito lodoso de Galicia. 


\section{Introduction}

In this work we present and analyze data from the Ocean Margin Exchange (OMEX) core KSGX 40, collected in the Galicia muddy patch (NW Iberian continental shelf) (fig. 1).

The OMEX project aims to gain a better understanding of the physical, chemical, biological and sedimentological processes that occur at the ocean margin of the European continental shelf in order to quantify energy and matter fluxes across this boundary.

The main features of the NW Iberian continental shelf that define the circulation, transport and deposition of fine sediments were discussed by Jouanneau et al. (1998) and Dias et al. (2002a, b). Araujo et al. (2002) studied the geochemistry of the sediments from both the Galicia and Douro muddy deposits and Oliveira et al. (2002) studied the distribution of clay minerals in the same sediments. The Iberian continental margin is affected by coastal upwelling (Frouin et al., 1990), responsible for the high oceanic productivity in the region.

This area is characterized by a high energy regime where hydrodynamic forces are capable of transporting and reworking sediments as deep as $100 \mathrm{~m}$ (Dias et al. 2002a, b). In the outer continental shelf, the transport ability of oceanic currents is reduced, allowing the sinking of fine particulate matter enriched in heavy metals either of natural or anthropic origin, supplied by the Galician rías and the rivers of northern Portugal. They discharge into the continental shelf, with maximum discharges during winter (Araujo et al., 2002). There is also some atmospheric supply of this elements.

In the present work, the distribution of $\mathrm{Al}, \mathrm{Ca}, \mathrm{Fe}, \mathrm{Mg}, \mathrm{Cu}$, $\mathrm{Pb}, \mathrm{Zn}, \mathrm{Cr}, \mathrm{Co}, \mathrm{Ni}$ and $\mathrm{Cd}$ concentrations in sediments from the KSGX 40 core is discussed and related to textural, mineralogical and micropaleontological (benthic and planktonic foraminifera) data with the aims of checking for a possible climatic change record during sedimentation.

\section{Materials and methods}

The OMEX KSGX 40 core (164 cm long) was collected from the muddy patch $\left(42^{\circ} 14^{\prime} 98^{\prime \prime} \mathrm{N}, 09^{\circ} 01^{\prime} 01^{\prime \prime} \mathrm{W}\right)$ located at the Galician continental shelf off Ría de Vigo (fig. 1), at a sea depth of $115 \mathrm{~m}$.

The grain size analysis was carried out using a Malvern $3600 \mathrm{E}$ laser diffraction particle sizer, which provided the grain size distribution in the $0.05-878 \mu \mathrm{m}$ size range. Calcium carbonate content was determined by a gasometric method.

To reduce the effects of sediment variable grain size, only the fine fractions $(<63 \mu \mathrm{m})$ were analyzed. These fractions were obtained by wet sieving and dried at $60^{\circ} \mathrm{C}$. Chemical element concentrations in the sediment samples studied were determined following the method proposed by Lecomte and Sondag (1980): $1 \mathrm{~g}$ of sediment was digested with a mixture of $3 \mathrm{~mL}$ of $\mathrm{HCl}(37 \%), 2 \mathrm{~mL}$ of $\mathrm{HNO}_{3}(65 \%)$ and $1 \mathrm{~mL}$ of $\mathrm{HF}$ (40\%). After drying at $120^{\circ} \mathrm{C}$, the residue was mixed with $10 \mathrm{~mL}$ of $\mathrm{HNO}_{3}$. The resulting solution was centrifuged,

\section{Introducción}

En el presente trabajo se presentan y analizan datos del sondeo KSGX 40 del proyecto Ocean Margin Exchange (OMEX), recolectado de un depósito lodoso en Galicia (NW de la plataforma continental ibérica) (fig. 1).

El objetivo del proyecto OMEX es entender mejor los procesos físicos, químicos, biológicos y sedimentológicos que ocurren en el margen oceánico de la plataforma continental europea, para poder cuantificar los flujos de energía y materia a través de este confín.

Las principales características del NW de la plataforma continental ibérica que definen la circulación, el transporte y el depósito de sedimentos finos han sido descritos por Jouanneau et al. (1998) y Dias et al. (2002a, b). Araujo et al. (2002) estudiaron la geoquímica de los sedimentos de los depósitos lodosos de Galicia y Douro, y Oliveira et al. (2002) estudiaron la distribución de minerales arcillosos en estos mismos sedimentos. El margen continental ibérico está influenciado por surgencias costeras (Frouin et al., 1990), responsables de la alta productividad oceánica de la región.

Esta zona se caracteriza por un régimen de alta energía, en el que las fuerzas hidrodinámicas pueden transportar y

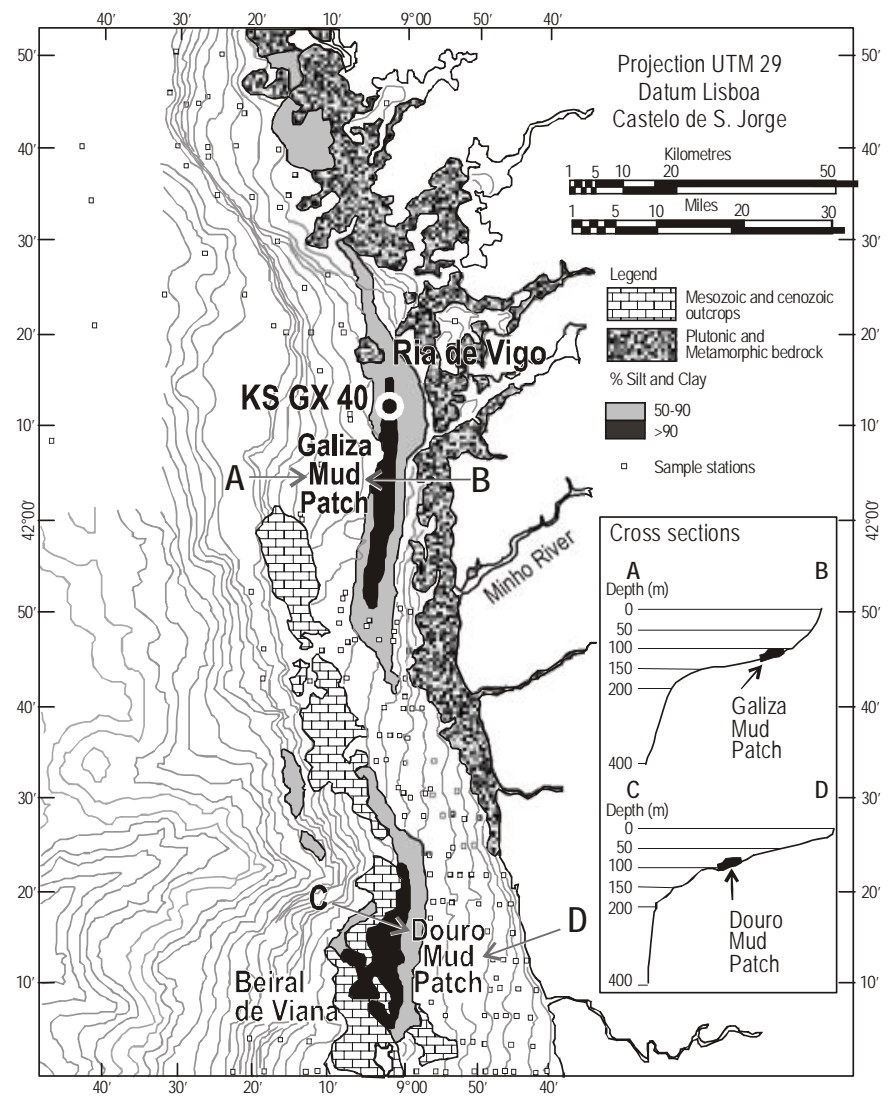

Figure 1. Location of OMEX core KSGX 40 (adapted from Dias et al., 2002a).

Figura 1. Localización del sondeo KSGX 40 de OMEX (adaptado de Dias et al., 2002a). 
filtered and mixed with demineralized water. Determinations of $\mathrm{Al}, \mathrm{Ca}, \mathrm{Cd}, \mathrm{Co}, \mathrm{Cr}, \mathrm{Cu}, \mathrm{Fe}, \mathrm{Mg}, \mathrm{Mn}, \mathrm{Ni}, \mathrm{Pb}$ and $\mathrm{Zn}$ were carried out by flame atomic absorption spectrometry on a GBC 600 spectrophotometer.

Mineralogical studies were conducted on the $<2 \mu \mathrm{m}$ sediment size fraction using $\mathrm{X}$-ray diffraction techniques. The clay fraction $(<2 \mu \mathrm{m})$ was obtained by conventional sedimentation techniques, according to Stokes' Law. Qualitative and semiquantitative mineralogical analyses of the clay fractions followed the criteria recommended by Schultz (1964), Barahona (1974), Thorez (1976), Mellinger (1979) and Pevear and Mumpton (1989).

Biostratigraphic and palaeoecological studies based on benthic foraminifera and the assessment of the relative contents of terrigenous and biogenic components were carried out using a binocular on the $>63 \mu \mathrm{m}$ sediment fraction of samples collected every centimeter along the core. We determined the evolution of the total abundance of endofaunal species characteristic of the inner and middle shelf (less than $50 \mathrm{~m}$ depth), which are markers of both high organic matter contents and low oxygen contents, as well as that of suspension feeders associated with temperate/cold waters. Also, species diversity was assessed using the Shannon-Wiener index (according to Shannon, 1948):

$$
H_{(s)}=-\sum_{n i=1}^{s} p i \ln p i
$$

where $H$ is the information function, $p i$ is the proportion of species and $S$ the number of species. The total density of foraminifera (number of shells per gram of sediment) and the density of autochthonous benthic foraminifera (deposited in situ, without evidence of transport) were also determined.

For ${ }^{14} \mathrm{C}$ dating using AMS (accelerator mass spectrometry), 10-20 mg of foraminifera shells were separated from the sediment fractions $>125 \mu \mathrm{m}$ corresponding to the sediment layers of 39-40 cm, 69-70 cm and 134-135 cm, in the laboratory of Beta Analytic Inc., Miami, Florida (USA).

The data obtained were subjected to multivariate statistical analysis (principal components analysis and Pearson correlations) using the Statistica (v. 5.1) software.

\section{Results}

Carbon-14 dating provided ages for three sediment layers (table 1). The intercalated ages were estimated on the basis of these values. Core KSGX 40 contains sediments that were deposited during the last 5200 years BP.

The KSGX 40 core consists, from the base to the top, of a sedimentary sequence exhibiting gradual upward decrease of grain size (fig. 2). In the upper section of the core, approximately from the depth of $100 \mathrm{~cm}$ upwards, the fine fraction of sediment $<63$ (silt + clay) is abundant (60-90\%), whereas the retrabajar los sedimentos hasta profundidades de $100 \mathrm{~m}$ (Dias et al. 2002a, b). En la plataforma continental exterior la capacidad de transporte de las corrientes oceánicas disminuye, lo que permite el hundimiento de la materia particulada fina enriquecida con metales pesados de origen tanto natural como antropogénico, aportados por las rías de Galicia y los ríos del norte de Portugal. Éstos descargan en la plataforma continental, con máxima descarga en invierno (Araujo et al., 2002). También hay aporte atmosférico de estos elementos.

En este estudio se discute la distribución de las concentraciones de $\mathrm{Al}, \mathrm{Ca}, \mathrm{Fe}, \mathrm{Mg}, \mathrm{Cu}, \mathrm{Pb}, \mathrm{Zn}, \mathrm{Cr}, \mathrm{Co}$, Ni y Cd en sedimentos del sondeo KSGX 40 y se relaciona con datos texturales, mineralógicos y micropaleontológicos (foraminíferos bentónicos y planctónicos) con el propósito de determinar un posible registro del cambio climático durante la sedimentación.

\section{Materiales y métodos}

El sondeo KSGX 40 de OMEX (164 cm de largo) fue recolectado de un depósito lodoso $\left(42^{\circ} 14^{\prime} 98^{\prime \prime} \mathrm{N}, 09^{\circ} 01^{\prime} 01^{\prime \prime} \mathrm{W}\right.$ ) localizado en la plataforma continental de Galicia frente a la Ría de Vigo (fig. 1), a una profundidad del mar de $115 \mathrm{~m}$.

Para el análisis del tamaño de grano se utilizó un analizador de tamaño de partícula por difracción láser (Malvern 3600E), el cual proporcionó la distribución del tamaño de grano en el intervalo de 0.05 a $878 \mu \mathrm{m}$. Se determinó el contenido de carbonato de calcio mediante un método gasométrico.

Para reducir los efectos del tamaño variable de los granos de sedimento, sólo se analizaron las fracciones finas $(<63 \mu \mathrm{m})$. Estas fracciones se obtuvieron mediante tamizado en húmedo y se secaron a $60^{\circ} \mathrm{C}$. Las concentraciones de los elementos químicos en las muestras de sedimento estudiadas se determinaron de acuerdo con el método propuesto por Lecomte y Sondag (1980): se digirió $1 \mathrm{~g}$ de sedimento con una mezcla de $3 \mathrm{~mL}$ de $\mathrm{HCl}$ (37\%), $2 \mathrm{~mL}$ de $\mathrm{HNO}_{3}$ (65\%) y $1 \mathrm{~mL}$ de $\mathrm{HF}(40 \%)$; se secó a $120^{\circ} \mathrm{C}$ y el residuo se mezcló con $10 \mathrm{~mL}$ de $\mathrm{HNO}_{3}$. La solución resultante se centrifugó, filtró y mezcló con agua desmineralizada. Se realizaron determinaciones de $\mathrm{Al}, \mathrm{Ca}, \mathrm{Cd}$, $\mathrm{Co}, \mathrm{Cr}, \mathrm{Cu}, \mathrm{Fe}, \mathrm{Mg}, \mathrm{Mn}, \mathrm{Ni}, \mathrm{Pb}$ y Zn mediante espectroscopía de absorción atómica con llama en un espectrofotómetro GBC 600.

Se llevaron a cabo estudios mineralógicos de la fracción de sedimento $<2 \mu \mathrm{m}$ utilizando técnicas de difracción por rayos X. La fracción arcillosa ( $<2 \mu \mathrm{m})$ fue obtenida con técnicas de sedimentación convencionales, de acuerdo con la ley de Stokes. Los análisis mineralógicos cualitativos y semicuantitativos de las fracciones arcillosas se hicieron utilizando los criterios recomendados por Schultz (1964), Barahona (1974), Thorez (1976), Mellinger (1979) y Pevear y Mumpton (1989).

Se realizaron estudios bioestratigráficos y paleoecológicos basados en foraminíferos bentónicos, así como la evaluación de los contenidos relativos de componentes terrígenos y biogénicos, usando un binocular, de la fracción de sedimento $>63 \mu \mathrm{m}$ de muestras recolectadas cada centímetro a lo largo del sondeo. Se determinó la evolución de la abundancia total de las especies endofaunales características de la plataforma interna y 
Table 1. Radiocarbon ages (using accelerator mass spectrometry, AMS).

Tabla 1. Edades determinadas mediante datación por ${ }^{14} \mathrm{C}$ (usando espectrometría acelerada de masa).

\begin{tabular}{cccc}
\hline Level & $\begin{array}{c}\text { Measured } \\
\text { radiocarbon age }\end{array}$ & $\begin{array}{c}\text { Conventional } \\
\text { radiocarbon age }\end{array}$ & 2 Sigma calibrated age \\
\hline $39-40 \mathrm{~cm}$ & $1.110 \pm 40 \mathrm{BP}$ & $1.500 \pm 40 \mathrm{BP}$ & $\begin{array}{c}\text { Cal AD } 800 \text { to } 1000 \\
\text { Cal BP 1.114 to } 950(=1045 \pm 95)\end{array}$ \\
$69-70 \mathrm{~cm}$ & $2.270 \pm 40 \mathrm{BP}$ & $2.680 \pm 40 \mathrm{BP}$ & $\begin{array}{c}\text { Cal BC } 510 \text { to } 350 \\
\text { Cal BP 2.460 to } 2.300(2380 \pm 80)\end{array}$ \\
$134-135 \mathrm{~cm}$ & $3.820 \pm 40 \mathrm{BP}$ & $4.250 \pm 40 \mathrm{BP}$ & $\begin{array}{c}\text { Cal BC } 2.490 \text { to } 2.290 \\
\text { Cal BP 4.440 to } 4.240(4340 \pm 100)\end{array}$ \\
\hline
\end{tabular}

sand fraction $(>63 \mu \mathrm{m})$ becomes more abundant in the lower section of the core (fig. 2).

The relative abundance of non-cohesive sediment particles presents values $>65 \%$ in the $33-55 \mathrm{~cm}$ sections and below $76 \mathrm{~cm}$ (fig. 2). The $\mathrm{CaCO}_{3}$ content ranges from $2 \%$ to $18 \%$ of the dry sediment weight and is higher in the lower section of the core (fig. 2). Foraminifera and mollusc shells are important sediment biogenic components, significantly contributing to the total sediment $\mathrm{CaCO}_{3}$.

Illite $(50-75 \%)$ is the predominant clay mineral, followed by kaolinite (16-18\%), smectite (0-15\%) and chlorite (2$10 \%)$. Illite and kaolinite, as well as chlorite and smectite, vary in an opposite way along the core studied (fig. 3).

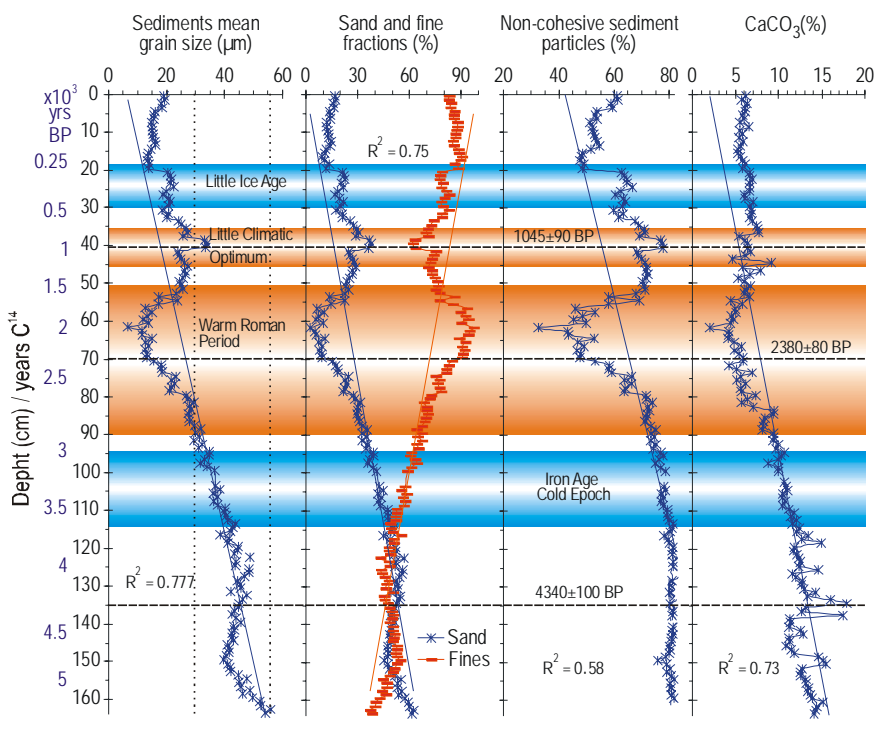

Figure 2. Vertical evolution of sediment mean grain size, sediment silt and sand fractions, non-cohesive particles and $\mathrm{CaCO}_{3}$ content. In these logs, the means, the moving average of values, the trend line and the ages corresponding to the ${ }^{14} \mathrm{C}$ dated sedimentary layers are also represented.

Figura 2. Evolución vertical del tamaño de grano, de la fracción de limo y de arena, de las partículas no cohesivas y del contenido de $\mathrm{CaCO}_{3}$ del sedimento. En estos registros también se muestran los valores medios, las medias móviles, la línea de tendencia y las edades de las capas de sedimentos determinadas mediante datación por ${ }^{14} \mathrm{C}$. media ( $<50 \mathrm{~m}$ de profundidad) que indican tanto contenidos altos de materia orgánica como bajos de oxígeno, así como la de especies suspensívoras asociadas con aguas templadas/frías. Asimismo, se evaluó la diversidad de especies con el índice de Shannon-Wiener (según Shannon, 1948):

$$
H_{(s)}=-\sum_{n i=1}^{s} p i \ln p i
$$

donde $H$ es la función de información, pi es la proporción de especies y $S$ es el número de especies. También se determinaron la densidad total de foraminíferos (número de conchas por gramo de sedimento) y la densidad de foraminíferos bentónicos autóctonos (depositados in situ, sin evidencias de transporte).

Para la datación por ${ }^{14} \mathrm{C}$ (utilizando espectrometría acelerada de masa), en el laboratorio de Beta Analytic Inc. en Miami, Florida (EUA), se separaron 10-20 mg de conchas de foraminíferos de las fracciones de sedimento $>125 \mu \mathrm{m}$ correspondientes a las siguientes capas de sedimento: $39-40 \mathrm{~cm}$, 69-70 cm y 134-135 cm.

Los datos obtenidos fueron sometidos a análisis estadístico multivariante (análisis de componentes principales y correlaciones de Pearson) usando la paquetería Statistica (v. 5.1).

\section{Resultados}

La datación mediante ${ }^{14} \mathrm{C}$ arrojó edades para tres niveles de sedimento (tabla 1). Se estimaron las edades intercaladas sobre la base de estos valores. El sondeo KSGX 40 contiene sedimentos que fueron depositados durante los últimos 5200 años AP.

El sondeo KSGX 40 consiste, de la base a la parte superior, de una secuencia sedimentaria que disminuye gradualmente de tamaño de grano hacia arriba (fig. 2). En la parte superior del sondeo, aproximadamente de $100 \mathrm{~cm}$ de profundidad hacia arriba, la fracción de sedimento fino $<63 \mu \mathrm{m}$ (limo + arcilla) es abundante (60-90\%), mientras que la fracción de arena (>63 $\mu \mathrm{m}$ ) es más abundante en la parte inferior del sondeo (fig. 2). 


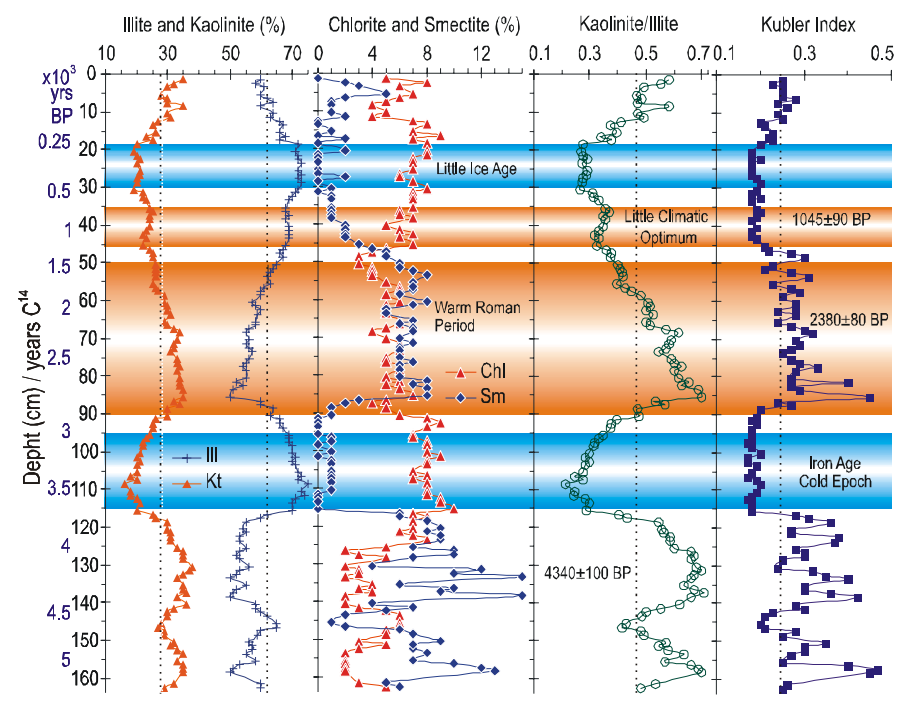

Figure 3. Vertical evolution of the clay mineral content, kaolinite/ilite ratio and Kubler index of illite crystallinity. Sediment layers dated by ${ }^{14} \mathrm{C}$ are marked.

Figura 3. Evolución vertical del contenido de mineral arcilloso, de la razón caolinita/ilita y del índice de Kubler de cristalinidad de la ilita. Se indican las capas de sedimento fechadas mediante ${ }^{14} \mathrm{C}$.

The values of the Kubler index of illite crystallinity (Kubler, 1964; Segonzac, 1969) and the kaolinite/illite ratio are higher in two particular sections of the core, between 164 and $120 \mathrm{~cm}$, and between 85 and $45 \mathrm{~cm}$, and show a tendency to increase between 20 and $0 \mathrm{~cm}$ (fig. 3).

In the 164-115 cm section, higher contents of kaolinite and smectite occur. In the 115-95 cm section, the abundance of these clay minerals decreases, but illite and chlorite contents increase. In the 90-50 cm section, smectite content increases and kaolinite content shows the highest values despite the reduction of kaolinite content starting at $85 \mathrm{~cm}$ (fig. 3). In the sediments of the upper $50 \mathrm{~cm}$ of the core, chlorite persists in higher contents whereas smectite is absent or rare. Between 18 and $30 \mathrm{~cm}$, the kaolinite/illite ratio decreases notably (fig. 3).

Pyrite is always present along the core, both in the sand fractions as framboidal sedimentary deposits and in pyritized shells of benthic foraminifera.

Benthic foraminifera assemblages along core KSGX 40 consist of autochthonous individuals (not showing transport marks) and of transported shells (broken or abraded).

The total number of foraminifera (benthic and planktonic) shells per gram of sediment is, as a rule, higher below the depth of $80 \mathrm{~cm}$ down to the basis of the core $(<6500$ shells per gram of sediment), this section also being characterized by a higher number of autochthonous benthic foraminifera and transported shells (fig. 4).

Some species of the benthic foraminifera assemblages found in core KSGX 40 are better represented in the inner and/ or middle shelf environments of this North Atlantic region. Such is the case of Ammonia beccarii, Asterigerinata mamila,
La abundancia relativa de partículas granulares no cohesivas muestra valores $>65 \%$ en la sección de 33 a $55 \mathrm{~cm}$ y debajo de $76 \mathrm{~cm}$ (fig. 2). El contenido de $\mathrm{CaCO}_{3}$ varía de $2 \%$ a $18 \%$ del peso de sedimento seco y es mayor en la sección inferior del sondeo (fig. 2). Las conchas de foraminíferos y moluscos son importantes componentes biogénicos de estos sedimento y contribuyen significativamente al $\mathrm{CaCO}_{3}$ total.

La ilita (50-75\%) es el mineral arcilloso predominante, seguida por la caolinita (16-18\%), la esmectita (0-15\%) y la clorita (2-10\%). La ilita y la caolinita, así como la clorita y la esmectita, varían de forma opuesta en el sondeo estudiado (fig. 3).

Los valores del índice de Kubler de cristalinidad de la ilita (Kubler, 1964; Segonzac, 1969) y la razón caolinita/ilita son mayores en dos secciones particulares del sondeo, entre $164 \mathrm{y}$ $120 \mathrm{~cm}$ y entre 85 y $45 \mathrm{~cm}$, y muestran una tendencia a incrementar entre 20 y $0 \mathrm{~cm}$ (fig. 3).

En la sección de 164 a $115 \mathrm{~cm}$ se encuentran contenidos mayores de caolinita y esmectita. En la sección de 115 a 95 cm, decrece la abundancia de estos minerales arcillosos, pero aumentan los contenidos de ilita y clorita. En la sección de 90 a $50 \mathrm{~cm}$ el contenido de esmectita se incrementa y el contenido de caolinita muestra sus valores más altos a pesar de que el contenido de este mineral se empieza a reducir a los $85 \mathrm{~cm}$ (fig. 3). En los sedimentos de los $50 \mathrm{~cm}$ superiores del sondeo persisten los elevados contenidos de clorita mientras que la esmectita es escasa o está ausente. Entre los 18 y $30 \mathrm{~cm}$ la razón caolinita/ilita decrece notablemente (fig. 3).

La pirita siempre está presente a lo largo del sondeo, tanto en las fracción de area en la forma de depósitos sedimentarios framboidales como en conchas piritizadas de foraminíferos bentónicos.

Las asociaciones de foraminíferos bentónicos en el sondeo KSGX 40 están formadas por individuos autóctonos (sin señales de transporte) y por conchas transportadas (rotas o gastadas).

El número total de conchas de foraminíferos (bentónicos y planctónicos) por gramo de sedimento es, en general, mayor por debajo de la profundidad de $80 \mathrm{~cm}$ hasta la base del sondeo ( $<6500$ conchas por gramo de sedimento), caracterizándose esta sección por un mayor número de foraminíferos bentónicos autóctonos y de conchas transportadas (fig. 4).

Algunas especies de las asociaciones de foraminíferos bentónicos están mejor representadas en los ambientes de la plataforma interna y/o media de esta región del Atlántico Norte. Tal es el caso de Ammonia beccarii, Asterigerinata mamila, Bolivina pseudoplicata, Cibicides ungerianus, Cribrononion gerthi, Discorbis mira, D. williamsoni, Eggerelloides scaber, Elphidium complanatum, E. crispum, E. discoidale, E. macellum var. aculeatum, E. pulvereum, Haynesina depressula, Lepidodeuterammina ochracea, Planorbulina mediterranensis, Quinqueloculina seminulum y Remaneica helgolandica (Pujos, 1976; Blanc-Vernet et al., 
Bolivina pseudoplicata, Cibicides ungerianus, Cribrononion gerthi, Discorbis mira, D. williamsoni, Eggerelloides scaber, Elphidium complanatum, E. crispum, E. discoidale, E. macellum var. aculeatum, E. pulvereum, Haynesina depressula, Lepidodeuterammina ochracea, Planorbulina mediterranensis, Quinqueloculina seminulum and Remaneica helgolandica (Pujos, 1976; Blanc-Vernet et al., 1984; Cearreta, 1986, 1989, 1994; Mathieu, 1986; Murray, 1991; Alve and Murray, 1994; Banner et al., 1994; Levy et al., 1995; Martins and Carapito, 1999; Mendes et al., 2004).

Hence, the number of foraminifera shells increases in the bottom section of core KSGX 40, where the sediment grain size increases, as does the number of species transported from both the inner and middle shelf and the diversity of benthic foraminifera species, expressed by the Shannon-Wiener index (fig. 4).

The Shannon-Wiener index values (or diversity of benthic foraminifera) decrease in the upper $70 \mathrm{~cm}$ of the core, i.e., in the last $2380 \pm 100$ years cal BP (fig. 4).

Throughout the core, the thanatocoenosis of benthic foraminifera is mainly composed of infaunal species (fig. 5), such as Bolivina dilatata, B. ordinaria, B. pseudoplicata, B. skagerrakensis, Brizalina spathulata, Bulimina exilis,

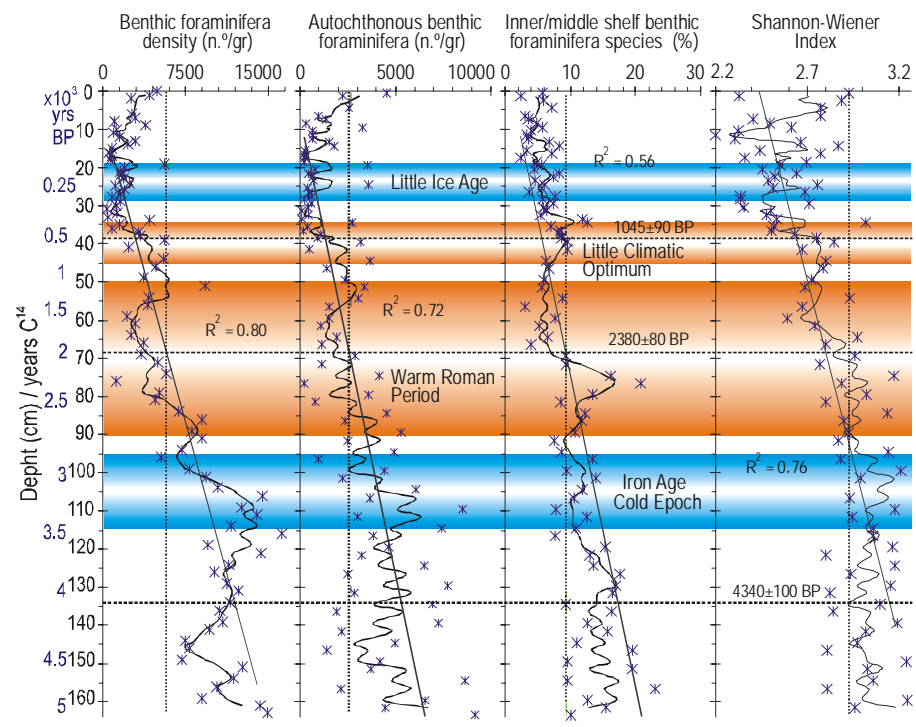

Figure 4. Vertical evolution of total foraminifera density, density of benthic autochthonous foraminifera, total relative abundance of species from the inner and middle shelf, and total relative abundance of suspension feeders, determined along the KSGX 40 core; and Shannon-Wiener Index values, representing the diversity of benthic foraminifera. In these logs, the means, the moving average values, the trend line and the ${ }^{14} \mathrm{C}$ dated sedimentary layers are also represented.

Figura 4. Evolución vertical de la densidad total de foraminíferos, de la densidad de foraminíferos autóctonos bentónicos, de la abundancia relativa total de especies de la plataforma interna y media, y de la abundancia relativa total de especies suspensívoras, determinadas a lo largo del sondeo KSGX 40; y valores del índice de Shannon-Wiener, que representan la diversidad de foraminíferos bentónicos. En estos registros también se muestran las medias, los promedios móviles, la tendencia y las edades de las capas de sedimento fechadas mediante ${ }^{14} \mathrm{C}$.
1984; Cearreta, 1986, 1989, 1994; Mathieu, 1986; Murray, 1991; Alve y Murray, 1994; Banner et al., 1994; Levy et al., 1995; Martins y Carapito, 1999; Mendes et al., 2004).

Por tanto, el número de conchas de foraminíferos aumenta en la sección inferior del sondeo KSGX 40, donde el tamaño de grano aumenta, al igual que el número de especies transportadas desde la plataforma interna y media, y la diversidad de especies de foraminíferos bentónicos, según lo expresa el índice de Shannon-Wiener (fig. 4).

Los valores del índice de Shannon-Wiener (o la diversidad de foraminíferos bentónicos) disminuyen en los $70 \mathrm{~cm}$ superiores del sondeo, i.e., en los pasados $2380 \pm 100$ años cal AP (fig. 4).

A lo largo de todo el sondeo, la tanatocenosis de foraminíferos bentónicos se compone principalmente de especies infaunales (fig. 5) tales como Bolivina dilatata, B. ordinaria, B. pseudoplicata, B. skagerrakensis, Brizalina spathulata, Bulimina exilis, Buliminella tenuata, Chilostomella oolina, C. ovoidea, Fursenkoina loeblichi, F. pauciloculata, Globobulimina spp., Nonionella bradyi, $N$. iridea, N. stella, N. turgida, Sphaeroidina bulloides, Stainforthia complanata, S. feylingi, S. fusiformis y Uvigerina peregrine (Corliss y

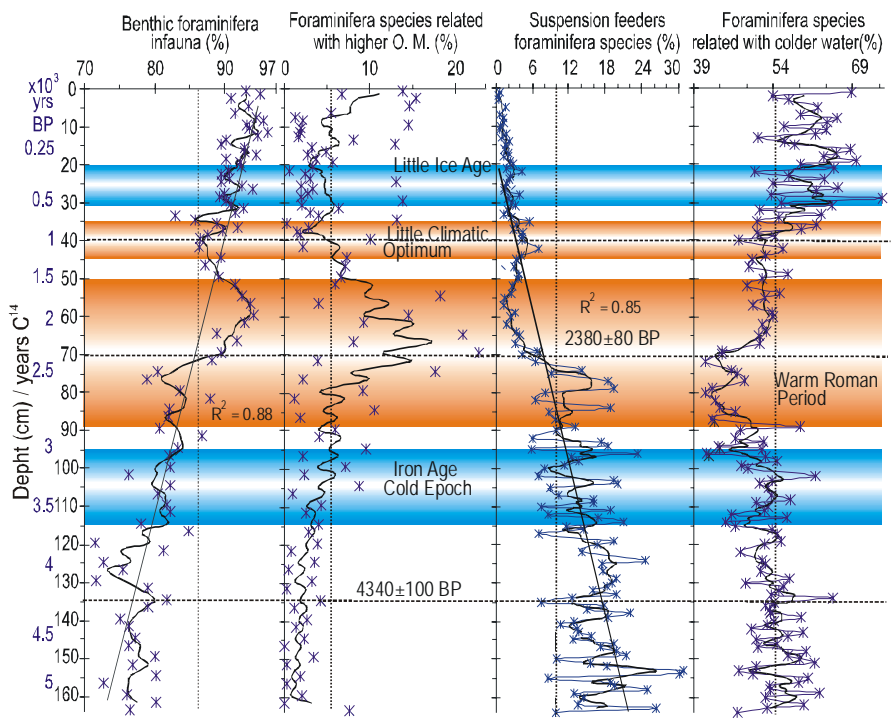

Figure 5. Vertical evolution of the total relative abundance of benthic foraminifera infauna, of species related to the highest organic matter content and lowest oxygen content in sediment, suspension-feeding benthic foraminifera species, and colder water species of outer neritic and bathyal environments. In these logs, the means, the moving average values, the trend line and the values of ${ }^{14} \mathrm{C}$ dating for some particular sediment layers are also represented.

Figura 5. Evolución vertical de la abundancia relativa total de la infauna de foraminíferos bentónicos, de las especies relacionadas con el mayor contenido de materia orgánica y el menor contenido de oxígeno en el sedimento, y de las especies suspensívoras de foraminíferos bentónicos y especies de aguas frías en ambientes batiales y neríticos exteriores. En estos registros también se muestran las medias, los promedios móviles, la tendencia y los valores de la datación por ${ }^{14} \mathrm{C}$ de algunas capas de sedimento en particular. 
Buliminella tenuata, Chilostomella oolina, C. ovoidea, Fursenkoina loeblichi, F. pauciloculata, Globobulimina spp., Nonionella bradyi, $N$. iridea, $N$. stella, $N$. turgida, Sphaeroidina bulloides, Stainforthia complanata, S. feylingi, S. fusiformis and Uvigerina peregrine (Corliss and Emerson, 1990; Corliss, 1991; Buzas et al., 1993; Rathburn and Corliss, 1994; Alve and Murray, 1995; Bernhard and Sen Gupta, 1999; Ernst, 2002).

The relative abundance of infaunal specimens increases from the base to the top of the core, but particularly from the $100-\mathrm{cm}$ level up to the top of the core (fig. 5).

The total relative abundance of species like Ammonia beccarii, Buliminella tenuata, Chilostomella oolina, C. ovoidea, Eggerelloides scaber, Fursenkoina loeblichi, F. pauciloculata, Globobulimina spp., Nonionella stella, N. turgida, Stainforthia complanata, S. feylingi and S. fusiformis, with higher tolerance to significant oxygen depletion in pore water, shows either dysoxic or microxic environments due to high availability of organic matter in the sediment (Mullineaux and Lohmann, 1981; van der Zwaan and Jörissen, 1991; Sen Gupta and Machain-Castillo, 1993; Moodley et al., 1997, 1998; Bernhard and Sen Gupta, 1999; van der Zwaan et al., 1999; Rijk et al., 1999; Ernst, 2002). This group of benthic foraminifera shows higher values in the core section of 90-50 cm (fig. 5), where the relative abundance of sediment fine fraction is higher (fig. 2). In the lower section of the core, the percentage of passive suspension feeders such as Cibicides refulgens, C. ungerianus, Discorbis mira, D. williamsoni, Discorbis spp., Dyocibicides bisserialis, Gavelinopsis praegeri, Hanzawaia nitidula, Lobatula lobatula, Paumotua terebra and Planorbulina mediterranensis, is higher (Murray, 1991; Vergnaud-Grazzini et al., 1989) (fig. 5).

Also present in the assemblages of core KSGX 40 is another group of benthic foraminifera, such as Amphicoryna scalaris, Bigenerina nodosaria, Bolivina albatrossi, $B$. difformis, B. dilatata, B. striatula, B. seminuda, B. robusta, B. skagerrakensis, Brizalina pacifica, B. spathulata, Bulimina exilis, B. aculeate, B. alazanensis, B. marginata, Cassidulina laevigata var. carinata, C. teretis, Cassidulinoides bradyi, Chilostomella oolina, Eggerella bradyi, Globocassidulina subglobosa, Hoeglundina elegans, Hyalinea balthica, Melonis barleeanum, M. pompilioides, Neolenticulina peregrina, Nonionella bradii, Sphaeroidina bulloides, Trifarina angulosa, Uvigerina peregrina and Valvulineria bradyana; however it is generally better represented in temperate/cold waters of outer neritic and bathyal environments (Pujos, 1976; Blanc-Vernet et al., 1984; Cearreta, 1986, 1989, 1994; Mathieu, 1986; Murray, 1991; Alve and Murray, 1994; Banner et al., 1994; Levy et al., 1995; Martins and Carapito, 1999; Mendes et al., in press). The total abundance of this group of benthic foraminifera is lower in the 90-50 cm core section and higher in the 115-95 cm and 30-18 cm core sections (fig. 5).

The chemical data determined are shown in figures 6, 7 and 8. All samples have $\mathrm{Cd}$ concentrations below the detection limit $\left(0.05 \mathrm{mg} \mathrm{kg}^{-1}\right)$.
Emerson, 1990; Corliss, 1991; Buzas et al., 1993; Rathburn y Corliss, 1994; Alve y Murray, 1995; Bernhard y Sen Gupta, 1999; Ernst, 2002).

La abundancia relativa de especímenes infaunales aumenta de la base a la parte superior del sondeo, pero en particular a partir del nivel de $100 \mathrm{~cm}$ hacia arriba (fig. 5).

La abundancia relativa total de especies como Ammonia beccarii, Buliminella tenuata, Chilostomella oolina, C. ovoidea, Eggerelloides scaber, Fursenkoina loeblichi, F. pauciloculata, Globobulimina spp., Nonionella stella, N. turgida, Stainforthia complanata, S. feylingi y S. fusiformis, que muestran mayor tolerancia a una reducción significativa del contenido de oxígeno en el agua intersticial, indica ambientes ya sea disóxicos o micróxicos, debido al elevado contenido de materia orgánica en el sedimento (Mullineaux y Lohmann, 1981; van der Zwaan y Jörissen, 1991; Sen Gupta y MachainCastillo, 1993; Moodley et al., 1997, 1998; Bernhard y Sen Gupta, 1999; van der Zwaan et al., 1999; Rijk et al., 1999; Ernst, 2002). Este grupo de foraminíferos bentónicos tiene mayor presencia en la sección del sondeo de 90 a $50 \mathrm{~cm}$ (fig. 5), donde la abundancia relativa de la fracción fina de los sedimentos es mayor (fig. 2). En la sección inferior del sondeo es mayor el porcentaje de suspensívoros pasivos (fig. 5) como Cibicides refulgens, C. ungerianus, Discorbis mira, D. williamsoni, Discorbis spp., Dyocibicides bisserialis, Gavelinopsis praegeri, Hanzawaia nitidula, Lobatula lobatula, Paumotua terebra y Planorbulina mediterranensis (Murray, 1991; Vergnaud-Grazzini et al., 1989).

En las asociaciones del sondeo KSGX 40 también se encuentra otro grupo de foraminíferos bentónicos, tales como Amphicoryna scalaris, Bigenerina nodosaria, Bolivina albatrossi, B. difformis, B. dilatata, B. striatula, B. seminuda, B. robusta, $B$. skagerrakensis, Brizalina pacifica, $B$. spathulata, Bulimina exilis, B. aculeate, B. alazanensis, B. marginata, Cassidulina laevigata var. carinata, C. teretis, Cassidulinoides bradyi, Chilostomella oolina, Eggerella bradyi, Globocassidulina subglobosa, Hoeglundina elegans, Hyalinea balthica, Melonis barleeanum, M. pompilioides, Neolenticulina peregrina, Nonionella bradii, Sphaeroidina bulloides, Trifarina angulosa, Uvigerina peregrina y Valvulineria bradyana; sin embargo, éste generalmente está mejor representado en aguas templadas/frías de ambientes neríticos y batiales más oceánicos (Pujos, 1976; Blanc-Vernet et al., 1984; Cearreta, 1986, 1989, 1994; Mathieu, 1986; Murray, 1991; Alve y Murray, 1994; Banner et al., 1994; Levy et al., 1995; Martins y Carapito, 1999; Mendes et al., en prensa). La abundancia total de este grupo de foraminíferos bentónicos es menor en la sección del sondeo de 90 a $50 \mathrm{~cm}$ y mayor en las de 115 a $95 \mathrm{~cm}$ y 30 a $18 \mathrm{~cm}$ (fig. 5).

En las figuras 6, 7 y 8 se presentan los datos químicos determinados. Todas las muestras tienen concentraciones de Cd menores que el límite de detección (0.05 mg kg-1).

El análisis de los registros que se presentan en las figuras 6 , 7 y 8 permitió definir dos zonas principales en el sondeo con 


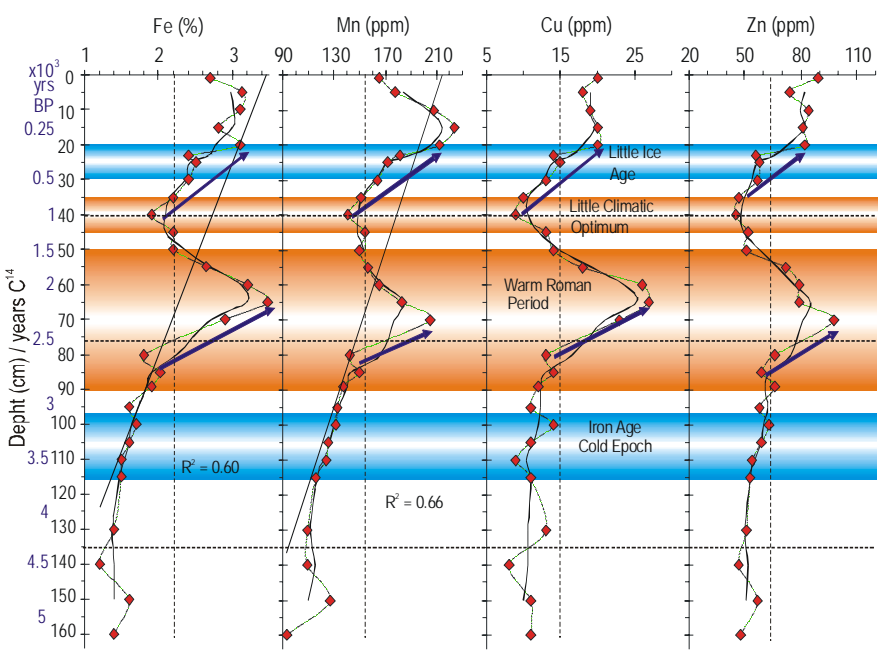

Figure 6. Vertical evolution, along the KSGX 40 core, of $\mathrm{Fe}, \mathrm{Mn}, \mathrm{Cu}, \mathrm{Zn}$, $\mathrm{Co}, \mathrm{Cr}$ and $\mathrm{Pb}$ concentrations. In these logs, the mean and the moving average values of the chemical element contents as well as the ${ }^{14} \mathrm{C}$ dated sedimentary layers are also represented.

Figura 6. Evolución vertical, en el sondeo KSGX 40, de las concentraciones de $\mathrm{Fe}, \mathrm{Mn}, \mathrm{Cu}, \mathrm{Zn}, \mathrm{Cr}$ y $\mathrm{Pb}$. En estos registros también se muestran los valores medios y los promedios móviles de los contenidos de los elementos químicos, así como las capas de sedimentos determinadas mediante datación por ${ }^{14} \mathrm{C}$.

The analysis of the logs shown in figures 6,7 and 8 allowed the definition of two main zones in the core in relation to the distribution of the chemical element concentration values: zone 1, above the $80 \mathrm{~cm}$ level, is characterized by higher (than below this level) concentrations of $\mathrm{Fe}, \mathrm{Mn}$ and $\mathrm{Co}$, and two concentration maxima for $\mathrm{Fe}, \mathrm{Mn}, \mathrm{Zn}, \mathrm{Co}, \mathrm{Cu}, \mathrm{Cr}$ and $\mathrm{Pb}$ identified approximately at $80-50 \mathrm{~cm}$ and $20-0 \mathrm{~cm}$; zone 2, below the $80 \mathrm{~cm}$ level, is characterized by higher $\mathrm{Ca}, \mathrm{Mg}$ and Al concentrations that decrease at $80-50 \mathrm{~cm}$ and $20-0 \mathrm{~cm}$, where the elements referred to in zone 1 show higher concentrations.

The values of Ca concentration decrease, as a rule, from the base to the top of the core, whereas Fe, Mn and Co concentrations show an opposite trend.

Spearman's correlations between chemical element concentrations and textural, mineralogical and micropaleontological parameters subjected to principal components analysis (fig. 9), allowed the definition of the following groups of parameters:

- Group 1, associated with the sediment sand fraction (>63 $\mu \mathrm{m}$ ), comprises the following parameters: $\mathrm{Ca}$ and $\mathrm{CaCO}_{3}$ contents, foraminifera density and total number of suspension feeders. These parameters show significant positive correlations between them, whereas significant negative correlations were found with the parameters of group 2.

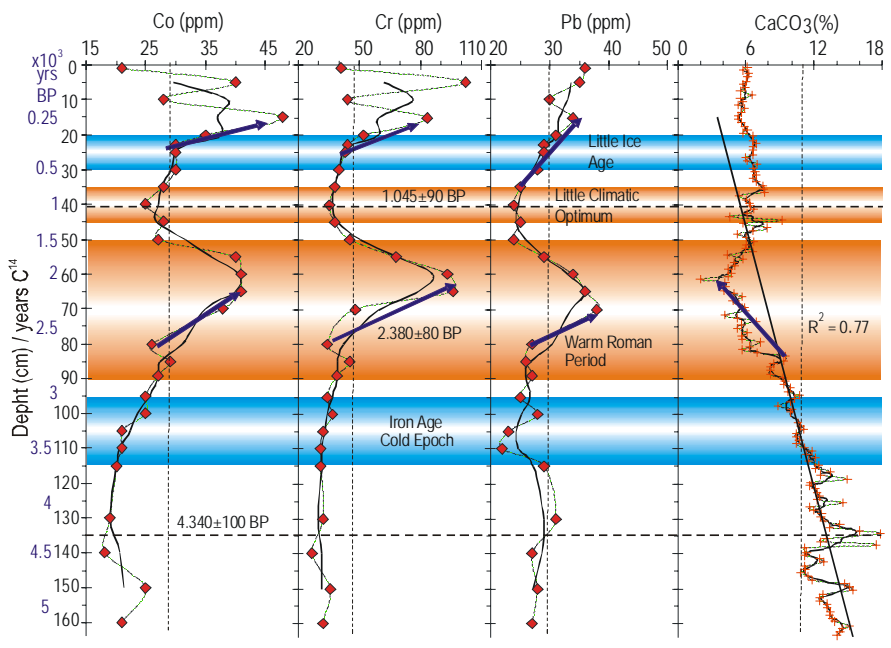

Figure 7. Vertical evolution, along the KSGX 40 core, of the $\mathrm{Co}, \mathrm{Cr}, \mathrm{Pb}$ and $\mathrm{CaCO}_{3}$ concentrations. In these logs, the mean and the moving average values of the chemical element contents as well as the ${ }^{14} \mathrm{C}$ dated sedimentary layers are also represented.

Figura 7. Evolución vertical en el sondeo KSGX 40, de las concentraciones de $\mathrm{Co}, \mathrm{Cr}, \mathrm{Pb}$ y $\mathrm{CaCO}_{3}$. En estos registros también se muestran los valores medios y los promedios móviles de los contenidos de los elementos químicos, así como las capas de sedimentos fechadas mediante ${ }^{14} \mathrm{C}$.

relación a la distribución de los valores de concentración de los elementos: la zona 1, por arriba del nivel de $80 \mathrm{~cm}$, se caracteriza por concentraciones mayores (que por debajo de este nivel) de $\mathrm{Fe}$, Mn y Co, pudiéndose identificar dos concentraciones máximas para $\mathrm{Fe}, \mathrm{Mn}, \mathrm{Zn}, \mathrm{Co}, \mathrm{Cu}, \mathrm{Cr}$ y $\mathrm{Pb}$ de $80 \mathrm{a}$ $50 \mathrm{~cm}$ y de 20 a $0 \mathrm{~cm}$; la zona 2, por abajo del nivel de $80 \mathrm{~cm}$, se caracteriza por concentraciones mayores de $\mathrm{Ca}, \mathrm{Mg}$ y $\mathrm{Al}$ que disminuyen de 80 a $50 \mathrm{~cm}$ y de 20 a $0 \mathrm{~cm}$, donde los elementos referidos para la zona 1 muestran concentraciones mayores.

Los valores de la concentración de Ca disminuyen, por lo general, de la base hacia la parte superior del sondeo, mientras que las concentraciones de Fe, Mn y Co muestran una tendencia opuesta.

Las correlaciones de Spearman entre las concentraciones de los elementos químicos y los parámetros texturales, mineralógicos y micropaleontológicos a los que se les aplicó el análisis de componentes principales (fig. 9), permitieron definir los siguientes grupos de parámetros:

- El grupo 1, asociado con la fracción de sedimento arenoso (>63 $\mu \mathrm{m}$ ), comprende los siguientes parámetros: contenidos de $\mathrm{Ca}$ y $\mathrm{CaCO}_{3}$, densidad de foraminíferos y número total de suspensívoros. Estos parámetros muestran correlaciones positivas significativas entre ellos, mientras que se encontraron correlaciones negativas significativas con los parámetros del grupo 2. 


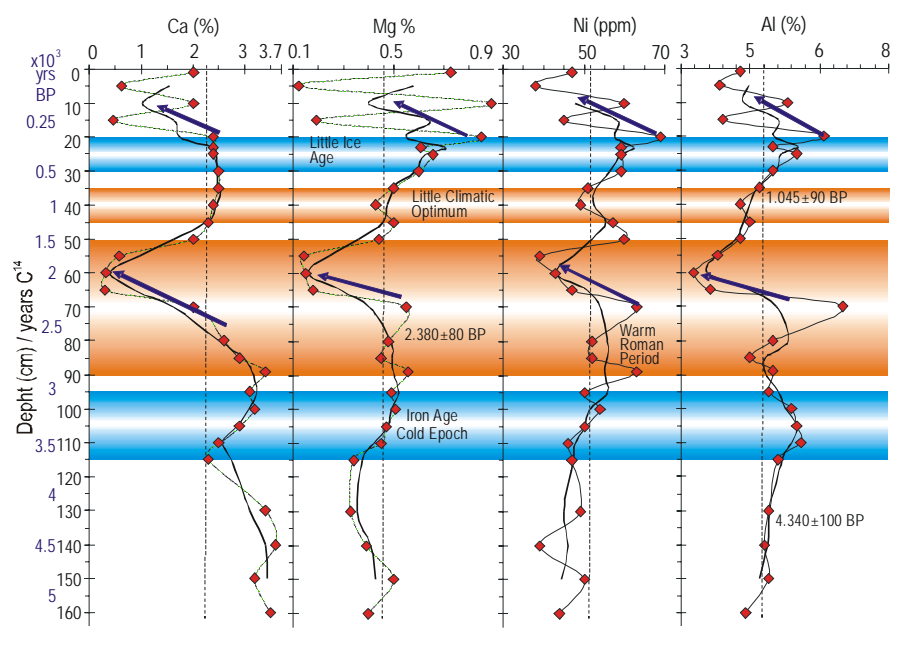

Figure 8. Logs showing the evolution, along the KSGX 40 core, of $\mathrm{Ca}, \mathrm{Mg}$, $\mathrm{Ni}$ and $\mathrm{Al}$ concentrations. In these logs, the mean of values and the moving average values of the chemical element contents as well as the ${ }^{14} \mathrm{C}$ dated sedimentary layers are also represented.

Figura 8. Registros que muestran la evolución, en el sondeo KSGX 40, de las concentraciones de $\mathrm{Ca}, \mathrm{Mg}, \mathrm{Ni}$ y $\mathrm{Al}$. En estos registros también se muestran los valores medios y los promedios móviles de los contenidos de los elementos químicos, así como las capas fechadas mediante ${ }^{14} \mathrm{C}$.

- Group 2, associated with sediment fine fractions (<63 and $<15 \mu \mathrm{m}$ ), comprises the following parameters: $\mathrm{Fe}, \mathrm{Mn}, \mathrm{Cu}$, $\mathrm{Zn}, \mathrm{Pb}, \mathrm{Co}$ and $\mathrm{Cr}$ concentrations. These concentrations exhibit significant positive correlations with the endofauna of benthic foraminifera and with the total number of species related to high organic matter and low oxygen contents.

- Group 3, associated with the clay minerals chlorite and illite and with benthic foraminifera characteristic of cold waters, comprises the following parameters: $\mathrm{Al}, \mathrm{Ni}$ and $\mathrm{Mg}$ concentrations, which show significant positive correlations between them.

- Group 4, associated with the clay minerals kaolinite and smectite, consists of parameters considered markers of relatively warm and wet climates that prevail in the source areas of clay mineral genesis.

Principal components analysis (fig. 9) allows the distinction of two main factors important for the definition of the groups identified. Altogether, factors 1 and 2 explain $71 \%$ of the variance of the data used; these factors are shown in table 2. Factor 1 represents the distribution of the parameters of groups 1 and 2, whereas factor 2 is related to the parameters of groups 3 and 4.

Factor 1 seems to be associated with sediment texture. On the one hand, heavy metal concentrations in the sediments increase as the fine fraction and organic matter contents increase and oxygen content decreases. On the other hand, coarse sediments deposited under more energetic

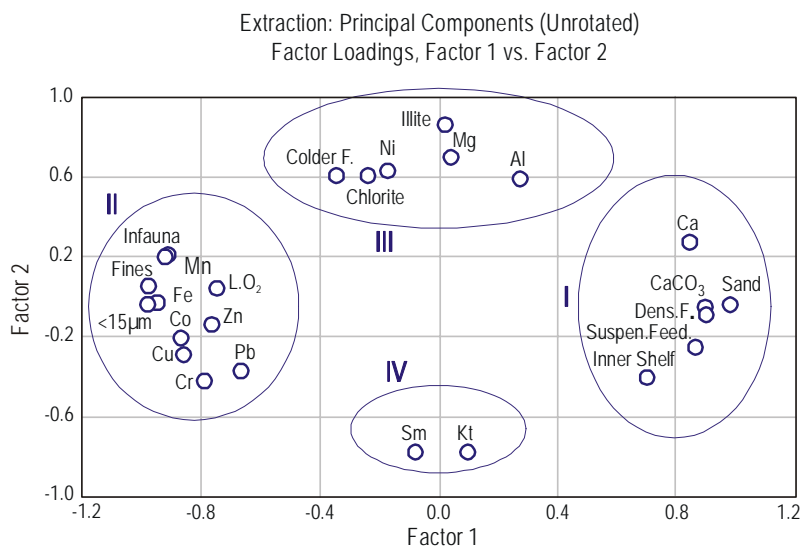

Figure 9. Principal components factor loadings: factor 1 vs 2. L. $\mathrm{O}_{2}=$ benthic foraminifera related to the highest organic matter and the lowest $\mathrm{O}_{2}$ in sediments; ColderF. $=$ species related to colder water; Suspend.Feed. $=$ suspension feeders; Inner Shelf = species from the inner and middle shelf; Cold $=$ cold water species; Carb. $=\mathrm{CaCO}_{3} ;$ Dens.F. $=$ density of foraminifera; $\mathrm{SM}=$ smectite; $\mathrm{Kt}=$ kaolinite.

Figura 9. Cargas factoriales de los componentes principales: factor 1 vs 2. L. $\mathrm{O}_{2}=$ foraminíferos bentónicos relacionados con los mayores contenidos de materia orgánica y los menores de $\mathrm{O}_{2}$ en sedimentos; ColderF. = especies relacionadas con aguas más frías; Suspend.Feed. = especies suspensívoras; Inner Shelf = especies de la plataforma interna y media; Cold = especies de aguas frías; Carb. $=\mathrm{CaCO}_{3}$; Dens.F. $=$ densidad de foraminíferos; $\mathrm{SM}$ = esmectita; $\mathrm{Kt}$ = caolinita.

- El grupo 2, asociado con las fracciones de sedimento fino ( $<63$ y $<15 \mu \mathrm{m})$, comprende los siguientes parámetros: concentraciones de Fe, Mn, $\mathrm{Cu}, \mathrm{Zn}, \mathrm{Pb}$, Co y Cr. Estas concentraciones muestran correlaciones positivas significativas con la endofauna de foraminíferos bentónicos y con el número total de las especies relacionadas con los contenidos altos de material orgánico y bajos de oxígeno.

- El grupo 3, asociado con los minerales arcillosos clorita e ilita y con los foraminíferos bentónicos característicos de aguas frías, comprende los siguientes parámetros: concentraciones de Al, Ni y Mg, los cuales muestran correlaciones positivas significativas entre ellos.

- El grupo 4, asociado con los minerales arcillosos caolinita y esmectita, está formado por parámetros considerados indicadores de climas relativamente templados y lluviosos que prevalecen en las áreas que son fuentes de la génesis de arcilla.

El análisis de componentes principales (fig. 9) permite distinguir dos factores principales importantes para la definición de los grupos identificados. En conjunto, los factores 1 y 2 explican $71 \%$ de la variancia de los datos usados; estos factores se muestran en la tabla 2. El factor 1 representa la distribución de los parámetros de los grupos 1 y 2, mientras que el factor 2 se relaciona con los parámetros de los grupos 3 y 4 .

El factor 1 parece estar asociado con la textura del sedimento. Por un lado, las concentraciones de metales pesados en los sedimentos aumentan conforme la fracción fina y los 
Table 2. Principal components factor loadings (loadings written in bold are $>0.70$ ).

Tabla 2. Cargas factoriales de los componentes principales (las cargas marcadas en negritas son $>0.70$ ).

\begin{tabular}{|c|c|c|}
\hline & Factor 1 & Factor 2 \\
\hline Chlorite & -0.24 & 0.61 \\
\hline Smectite & -0.08 & -0.78 \\
\hline Illite & 0.02 & 0.87 \\
\hline Kaolinite & 0.10 & -0.78 \\
\hline Forams. higher O.M. & -0.73 & 0.05 \\
\hline Suspension feeders & 0.86 & -0.26 \\
\hline Infauna & -0.92 & 0.21 \\
\hline Inner/middle shelf species & 0.70 & -0.40 \\
\hline Colder species & -0.34 & 0.61 \\
\hline $\mathrm{CaCO}_{3}$ & 0.89 & -0.05 \\
\hline Forams. density & 0.90 & -0.09 \\
\hline Sand & 0.98 & -0.04 \\
\hline Fine & -0.98 & 0.06 \\
\hline$<15 \mathrm{~m}$ & -0.95 & -0.03 \\
\hline $\mathrm{Cu}$ & -0.86 & -0.29 \\
\hline $\mathrm{Pb}$ & -0.66 & -0.37 \\
\hline $\mathrm{Ni}$ & -0.17 & 0.63 \\
\hline Co & -0.87 & -0.21 \\
\hline $\mathrm{Fe}$ & -0.98 & -0.04 \\
\hline $\mathrm{Zn}$ & -0.76 & -0.14 \\
\hline $\mathrm{Cr}$ & -0.79 & -0.42 \\
\hline Mn & -0.91 & 0.21 \\
\hline $\mathrm{Mg}$ & 0.04 & 0.70 \\
\hline $\mathrm{Ca}$ & 0.84 & 0.28 \\
\hline $\mathrm{Al}$ & 0.27 & 0.59 \\
\hline Var. (\%) & 52 & 19 \\
\hline
\end{tabular}

hydrodynamic conditions, expressed by higher concentrations of suspension feeding foraminifera, seem to favour the preservation of $\mathrm{CaCO}_{3}$, expressed by higher $\mathrm{Ca}, \mathrm{CaCO}_{3}$ and foraminifera shell contents in the sediments.

Factor 2 is particularly determined by clay mineral assemblages and by their dependence on the weather conditions prevailing at sediment source areas. Chlorite and illite, whose genesis is particularly favoured by cold and dry weather, are included in the same group of benthic foraminifera considered to be markers of cold waters, suggesting that most of the oceanic water cooling episodes occurred because of periods of colder climate. Smectite and kaolinite, whose genesis is particularly favoured by relatively warm and wet climate, are included in group 4. contenidos de materia orgánica auamentan y el contenido de oxígeno disminuye. Por otro lado, los sedimentos de grano grueso depositados en condiciones hidrodinámicas más energéticas evidenciadas por concentraciones mayores de foraminíferos suspensívoros, parecen favorecer la preservación de $\mathrm{CaCO}_{3}$ manifiesta en los mayores contenidos de $\mathrm{Ca}, \mathrm{CaCO}_{3} \mathrm{y}$ conchas de foraminíferos en los sedimentos.

El factor 2 está determinado particularmente por las asociaciones de minerales arcillosos y por su dependencia de las condiciones climáticas prevalecientes en las fuentes de sedimentos. La clorita y la ilita, cuya génesis se ve particularmente favorecida por climas fríos y secos, están incluidas en el mismo grupo de foraminíferos bentónicos considerados indicadores de aguas frías, lo que sugiere que la mayoría de los episodios de enfriamiento oceánico ocurrieron a causa de periodos de clima más frío. La esmectita y la caolinita, cuya génesis es particularmente favorecida por climas templados y lluviosos, están incluidas en el grupo 4.

Las concentraciones de $\mathrm{Ni}, \mathrm{Mg}$ y $\mathrm{Al}$ están incluidas en el grupo 3, relacionado con periodos de clima frío. No es fácil explicar esta asociación; sin embargo, se conoce que el plancton utiliza estos elementos químicos y que la productividad oceánica generalmente es mayor durante episodios fríos. Por ende, es posible que el aumento en la concentración de estos elementos podría estar relacionado con la acumulación de biodetritos como conecuencia de la alta productividad oceánica.

\section{Discusión}

La disminución gradual del tamaño de grano encontrada en el sondeo KSGX 40 probablemente se debe a la transgresión del mar ocurrida durante el Holoceno. Según Zazo et al. (1996), después de la máxima transgresión del Holoceno, alcanzada a los 6900 años AP, sucedió una pequeña caída del nivel del mar seguida por una pequeña elevación del mismo entre 2400 años y el presente.

Algunos cambios climáticos que se presentaron durante el Holoceno parecen haber condicionado el régimen sedimentario marino. Con base en los datos analíticos disponibles fue posible establecer las siguientes zonas en el sondeo KSGX 40.

\section{Zona 1}

La zona 1, que corresponde a la sección de 164 a $90 \mathrm{~cm}$, se caracteriza por: (a) sedimento de tamaño de grano grueso; (b) contenidos mayores de $\mathrm{Ca}, \mathrm{CaCO}_{3}$ y foraminíferos (número de foraminíferos bentónicos y planctónicos por gramo); (c) concentraciones mayores de $\mathrm{Mg}$, $\mathrm{Ni}$ y Al; (d) concentraciones menores de Fe, Mn, $\mathrm{Cu}, \mathrm{Zn}, \mathrm{Co}, \mathrm{Cr}$ y Pb; (e) mayor número de especies de foraminíferos característicos de la plataforma continental interna y media y mayor número de especies suspensívoras; y (f) asociaciones de ilita + caolinita + esmectita + clorita que indican la prevalencia de un clima generalmente templado y frío con oscilaciones intercaladas durante la depositación de sedimento. La ocurrencia de un periodo 
The concentrations of $\mathrm{Ni}, \mathrm{Mg}$ and $\mathrm{Al}$ are included in group 3, which is related to periods of cold climate. It is not easy to explain this association; however, it is known that plankton uses these chemical elements and that oceanic productivity is, as a rule, higher during cold episodes. Therefore, it is possible that the increase of the concentration of these elements could be related to the accumulation of biodetritus as a consequence of high oceanic productivity.

\section{Discussion}

The gradual grain size decrease found in core KSGX 40 could most probably be due to the sea transgression occurred during the Holocene. According to Zazo et al. (1996), after the Holocene transgressive maximum, reached at 6900 years BP, a small drop in the sea level occurred, followed by a small rise in its level between 2400 years and the present.

Some climatic changes that occurred during the Holocene appear to have conditioned the marine sedimentation regime. Based on the analytical data available it was possible to establish three zones in core KSGX 40.

\section{Zone 1}

Zone 1, corresponding to the $164-90 \mathrm{~cm}$ section, is characterized by: (a) coarse grain size sediment; (b) higher $\mathrm{Ca}$, $\mathrm{CaCO}_{3}$ and foraminifera (number of benthic and planktonic foraminifera per gram) contents; (c) higher $\mathrm{Mg}, \mathrm{Ni}$ and $\mathrm{Al}$ concentrations; (d) lower $\mathrm{Fe}, \mathrm{Mn}, \mathrm{Cu}, \mathrm{Zn}, \mathrm{Co}, \mathrm{Cr}$, and $\mathrm{Pb}$ concentrations; (e) higher number of foraminifera species characteristic of the inner and middle continental shelf and higher number of suspension feeders; and (f) illite + kaolinite + smectite + chlorite assemblages indicating a general temperate and wet climate with intercalated oscillations prevailing during sediment deposition. The occurrence of a relatively warm and wet period, corresponding to the core section from the base to the $120-\mathrm{cm}$ level, allowed the input of higher amounts of sediments characterized by coarser grain size into the oceanic system. Together with the terrigenous components, foraminifera were also transported from shallower zones of the shelf. The accumulation of coarse sediments on the outer shelf allowed the easier removal of sediment interstitial water, a fact that favoured the preservation of $\mathrm{CaCO}_{3}$ expressed by the relatively high $\mathrm{Ca}$ content found in sediments and by the fair preservation of foraminifera shells. This rainy period was identified in Europe by Bohncke and Vanderberghe (1991), Zolitschka and Negendank (1993), and Magri (1997).

In the sediment section between 120 and $90 \mathrm{~cm}$, the high content of illite + chlorite indicates the occurrence of relatively cold climatic conditions that prevailed in the continent at the time of the genesis of these clay minerals, 3800-3000 years cal BP. From the base to the top of this section, a decrease in smectite content associated with an increase in chlorite content was recorded in this subsection. Also, a decrease, in this same subsection, of the kaolite/illite ratio, allowed the identification of an episode of cold and dry climate, at least partially relativamente cálido y lluvioso, que en el sondeo corresponde a la sección de la base hasta el nivel de $120 \mathrm{~cm}$, permitió la entrada de mayores cantidades de sedimentos más gruesos al sistema oceánico. Junto con los componentes terrígenos también se transportaron foraminíferos desde las zonas menos profundas de la plataforma. La acumulación de sedimentos gruesos en la plataforma exterior permitió una más fácil remoción del agua intersticial del sedimento, lo que favoreció la preservación de $\mathrm{CaCO}_{3}$ expresada por el contenido relativamente alto de $\mathrm{Ca}$ en los sedimentos y la relativamente buena preservación de las conchas de foraminíferos. Este periodo lluvioso fue indentificado en Europa por Bohncke y Vanderberghe (1991), Zolitschka y Negendank (1993) y Magri (1997).

En la sección de sedimento de 120 a $90 \mathrm{~cm}$, el alto contenido de ilita + clorita indica la presencia de condiciones climáticas relativamente frías que prevalecieron en el continente durante el tiempo de la génesis de estos minerales arcillosos, 3800-3000 años cal AP. De la base a la parte superior de esta sección se registró una disminución en el contenido de esmectita asociado con un aumento en el contenido de clorita. Asimismo, una disminución en esta misma subsección de la razón caolinita/ilita permitió identificar un episodio climático frío y seco, por lo menos parcialmente responsable de la reducción en el aporte de arena al depósito estudiado. Este enfriamiento climático puede estar relacionado con la oscilación térmica conocida como la "Etapa de Lobben", alrededor de 3600 años AP (Ehlers, 1996), que causó la expansión de los glaciares en los Alpes suizos y austriacos.

\section{Zona 2}

La zona 2 corresponde a la sección de 90 a $50 \mathrm{~cm}$ en el sondeo KSGX 40 y se caracteriza por: (a) un rápido aumento en los contenidos de limo $(<63 \mu \mathrm{m})$ y limo fino + arcilla $(<15 \mu \mathrm{m})$; (b) reducción del contenido total de partículas no cohesivas; (c) reducción de los contenidos de $\mathrm{Ca}, \mathrm{Mg}, \mathrm{Ni}, \mathrm{Al}$, $\mathrm{CaCO}_{3}$ y foraminíferos; (d) concentraciones mayores de Fe, $\mathrm{Mn}, \mathrm{Cu}, \mathrm{Zn}, \mathrm{Co}, \mathrm{Cr}$ y P; (e) asociación de ilita + caolinita + clorita + esmectita, en la cual el contenido de esmectita y el índice de cristalinidad de ilita muestran un incremento gradual hacia la parte superior del sondeo, mientras que el contenido de caolinita decrece hacia la parte superior, siendo compensada por el aumento simétrico del contenido de ilita. Las asociaciones de minerales arcillosos mencionadas (disminución del contenido de caolinita y aumento del de esmectita) sugieren la ocurrencia de un periodo climático relativamente más cálido y seco entre 2900 y 1500 años cal AP. Foraminíferos bentónicos de agua templada/fría de ambientes batiales y neríticos externos también indican temperaturas mayores en el fondo oceánico durante este periodo. Esta variación de mejora climática empezó coincidiendo con el principio del Imperio Romano (Crowley y North, 1991), y ha sido mencionada para el área de Galicia por Cortizas et al. (1999, 2000). Un clima más seco y un nivel del mar más alto durante este periodo (mencionados 
responsible for a decrease in sand supply to the deposit studied. This climatic cooling could be related to the thermal oscillation, the "Lobben Stage", around 3600 years BP (Ehlers, 1996) that caused the expansion of the glaciers of the Austrian and Swiss Alps.

\section{Zone 2}

Zone 2 corresponds to the $90-50 \mathrm{~cm}$ section in core KSGX 40 and is characterized by: (a) a rapid increase in silt $(<63 \mu \mathrm{m})$ and fine silt + clay $(<15 \mu \mathrm{m})$ contents; (b) reduction of the total content of non-cohesive particles; (c) reduction of $\mathrm{Ca}, \mathrm{Mg}, \mathrm{Ni}, \mathrm{Al}, \mathrm{CaCO}_{3}$ and foraminifera contents; (d) higher $\mathrm{Fe}, \mathrm{Mn}, \mathrm{Cu}, \mathrm{Zn}, \mathrm{Co}, \mathrm{Cr}$ and $\mathrm{P}$ concentrations; (e) illite + kaolinite + chlorite + smectite assemblage, in which the smectite content and the illite crystallinity index exhibit a gradual increase towards the top of the core, whereas kaolinite content decreases being compensated by the symmetric increase of illite content. The clay mineral assemblages previously mentioned (kaolinite content decrease and smectite content increase), suggest the occurrence of a relatively warmer and dryer climatic period between 2900 and 1500 years cal BP. Temperate/cold water benthic foraminifera from outer neritic and bathyal environments also suggest higher oceanic temperatures on the bottom during this period. This ameliorating climatic oscillation began near the dawn of the Roman Empire (Crowley and North, 1991), and was reported in the Galician area by Cortizas et al. (1999, 2000). A dryer climate and a higher sea level during this period (mentioned by e.g. Fidalgo and Vidal-Romani, 1993; Fidalgo et al., 1993; Pascual et al., 1998) caused a higher deposition of finer sediments and organic matter.

The chemical elements $\mathrm{Fe}, \mathrm{Mn}, \mathrm{Cu}, \mathrm{Pb}, \mathrm{Zn}, \mathrm{Cr}$, $\mathrm{Co}$ and $\mathrm{Ni}$ are usually adsorbed onto sediments, particularly onto clay minerals, due to both their high specific surface area and global negative electric charge. This fact supports the significant positive correlation found between sediment fine silt + clay $(<15 \mu \mathrm{m})$ content and the concentration of these elements.

The main source of $\mathrm{Al}$ is lithogenic. This element participates largely in the structures of both primary and secondary aluminosilicates existing in weathered products, which are introduced into the oceanic system transported mainly by the rivers. However, $\mathrm{Al}$ contents show a weak positive correlation with the sediment fine fraction content and a significant negative correlation with the chemical elements of group 1 . The content of $\mathrm{Al}$ is reduced in this zone of the core, evidencing a decrease in the transport of fine clayey terrigenous sediments that could be compensated by higher deposition of organic matter, mostly transported laterally. Benthic foraminifera assemblages support this assumption, since a higher number of individuals associated with high organic matter content and infaunal species were found in this core section. A high consumption of oxygen by benthic fauna led to an oxygen depletion in sediments. por e.g. Fidalgo y Vidal-Romani, 1993; Fidalgo et al., 1993; Pascual et al., 1998) causaron una mayor depositación de sedimentos más finos y de materia orgánica.

Los elementos químicos $\mathrm{Fe}, \mathrm{Mn}, \mathrm{Cu}, \mathrm{Pb}, \mathrm{Zn}, \mathrm{Cr}$, Co y Ni se adsorben en los sedimentos, particularmente en minerales arcillosos, debido a su gran área superficial específica así como a su carga eléctrica negativa neta. Este hecho apoya la correlación positiva significativa encontrada entre el contenido de limo fino + arcilla $(<15 \mu \mathrm{m})$ y la concentración de los elementos químicos referidos.

La principal fuente de $\mathrm{Al}$ es litogénica. Este elemento participa ampliamente en las estructuras de aluminosilicatos primarias y secundarias que existen en productos intemperizados, los cuales son introducidos al sistema oceánico principalmente por los ríos. Sin embargo, los contenidos de Al muestran una correlación positiva débil con el contenido de la fracción fina y una correlación negativa significativa con los elementos químicos del grupo 1 . El contenido de $\mathrm{Al}$ disminuye en esta zona del sondeo, un hecho que refleja una reducción en el transporte de sedimentos terrígenos finos arcillosos y que pudiera estar compensado por el mayor depósito de materia orgánica, la mayoría transportada lateralmente. Las asociaciones de foraminíferos bentónicos apoyan este supuesto, ya que en esta sección del sondeo se encontró un mayor número de individuos asociados con el contenido de materia orgánica y especies infaunales. Un alto consumo de oxígeno por la fauna béntica resultó en una reducción de oxígeno en los sedimentos.

Las propiedades del sedimento pueden cambiar debido a procesos biológicos, físicos, químicos y diagenéticos (Zuo et al., 1991; Nolting y Helder, 1991). Un ambiente reductor en la interfase agua-sedimento genera las condiciones necesarias para el enriquecimiento diagenético (i.e., que sucede después de la depositación del sedimento) de metales que sufren un cambio de estado redox y se tornan menos solubles, o de metales que forman sulfuros insolubles. En esta zona el comportamiento redox del Fe y Mn puede jugar un papel central en el ciclo de otros metales que pueden ser adsorbidos en precipitados de Fe y Mn.

\section{Zona 3}

La zona 3 corresponde a la sección de 50 a $0 \mathrm{~cm}$ del sondeo KSGX 40 y a un clima similar al actual: Sub-Atlántico (frío y lluvioso). Esta zona comprende dos subzonas.

\section{Subzona 3.1}

La subzona 3.1 corresponde a la sección de 50 a 20 cm y se caracteriza por: (a) un pequeño aumento en la fracción de arena y un pequeño decremento en la fracción $<15 \mu \mathrm{m}$; (b) disminución de la razón caolinita/ilita; (c) aumento del contenido de clorita; (d) aumento en las concentraciones de $\mathrm{Al}, \mathrm{Ca}, \mathrm{Mg}$ y Ni; y (e) reducción de las concentraciones de $\mathrm{Fe}, \mathrm{Mn}, \mathrm{Cu}, \mathrm{Pb}, \mathrm{Zn}$, Cr y Co. 
Biological, physical, chemical and diagenetic processes can change the sediment properties (Zuo et al., 1991; Nolting and Helder, 1991). Reducing conditions at the sediment-water interface create the conditions needed for diagenetic enrichment (i.e. occuring after sediment deposition) of metals that undergo a redox change and become less soluble, or of metals that form insoluble sulphides. In this zone, Fe and Mn redox behaviour could play a central role in the cycling of other metals that can be adsorbed onto Fe and Mn precipitates.

\section{Zone 3}

Zone 3 corresponds to the $50-0 \mathrm{~cm}$ section of core KSGX 40 and to a climate similar to the actual climate: Sub-Atlantic (cold and wet). This zone comprises two sub-zones.

Sub-zone 3.1

Sub-zone 3.1 corresponds to core section $50-20 \mathrm{~cm}$ and is characterized by: (a) a slight increase in the sand fraction and a slight decrease in the $<15 \mu \mathrm{m}$ fraction; (b) decrease of the kaolinite/illite ratio; (c) increase of chlorite content; (d) increase of $\mathrm{Al}, \mathrm{Ca}, \mathrm{Mg}$ and $\mathrm{Ni}$ concentrations; and (e) reduction of $\mathrm{Fe}, \mathrm{Mn}, \mathrm{Cu}, \mathrm{Pb}, \mathrm{Zn}, \mathrm{Cr}$ and $\mathrm{Co}$ concentrations.

The increased $\mathrm{Al}$ content expresses the higher input of fine clayey terrigenous sediments relative to organic matter, justifying both the better preservation of $\mathrm{CaCO}_{3}$ and the higher Ca content values in the sediments. Less deposition of fine particles may have determined the lower contents of $\mathrm{Fe}, \mathrm{Mn}, \mathrm{Cu}$, $\mathrm{Pb}, \mathrm{Zn}, \mathrm{Cr}$ and $\mathrm{Co}$.

The higher illite and chlorite contents, as well as the higher content of benthic foraminifera associated with cold waters, present in the $30-18 \mathrm{~cm}$ core section, could be related to the climatic cooling episode-Little Ice Age, a neo-historical glacial fluctuation (between XVI and XIX centuries, according to Grove, 2001) - that seems to have caused lower sea water temperatures. On the other hand, the $46-35 \mathrm{~cm}$ core section could be related to the warmer episode-Little Climatic Optimumas described by Brown (1998). During these two climatic episodes, dry periods alternating with huge river floods would have occurred, expressed by the slight increase of the sand fraction content and $\mathrm{Al}$ concentration in the sediments.

\section{Sub-zone 3.2}

Sub-zone 3.2 , corresponding to the $20-0 \mathrm{~cm}$ core section, is characterized by: (a) a notable increase of the sediment fine fraction ( $<15 \mu \mathrm{m})$; (b) increased $\mathrm{Fe}, \mathrm{Mn}, \mathrm{Cu}, \mathrm{Pb}, \mathrm{Zn}, \mathrm{Cr}$ and Co concentrations; (c) the increase of the kaolinite/illite ratio; (d) decrease of chlorite content; and (e) decrease of $\mathrm{Al}$, $\mathrm{Ca}, \mathrm{Mg}$ and $\mathrm{Ni}$ concentrations. This section, corresponding to the subrecent period, shows similarities with the 90-50 cm section, with a higher accumulation of finer sediments and organic matter because of a tendency in the sea level to rise and lower hydrodynamics in the area where core KSGX 40 was collected.
$\mathrm{El}$ aumento en el contenido de $\mathrm{Al}$ refleja el mayor aporte de sedimentos terrígenos finos arcillosos con relación a la materia orgánica, justificando tanto la mejor preservación de $\mathrm{CaCO}_{3} \mathrm{y}$ el mayor contenido de Ca en los sedimentos. Un menor depósito de partículas finas pudo haber determinado los contenidos más bajos de $\mathrm{Fe}, \mathrm{Mn}, \mathrm{Cu}, \mathrm{Pb}, \mathrm{Zn}, \mathrm{Cr}$ y Co.

Los contenidos más altos de ilita y clorita, así como de foraminíferos bentónicos asociados con aguas frías, presentes en la sección del sondeo de 30 a $18 \mathrm{~cm}$, pueden estar relacionados con el episodio climático de enfriamiento-Pequeña Edad de Hielo, una fluctuación glacial neohistórica (entre los siglos XVI y XIX, según Grove, 2001)—que aparentemente generó temperaturas menores del agua de mar. Por otro lado, la sección del sondeo de 46 a $35 \mathrm{~cm}$ puede estar relacionada con el episodio más cálido-Pequeño Óptimo Climático—según descrito por Brown (1998). Durante estos dos periodos climáticos, se hubieran presentado periodos secos alternados con gran inundaciones fluviales, lo que se muestra por el pequeño incremento del contenido de la fracción de arena y la concentración de $\mathrm{Al}$ en los sedimentos.

\section{Subzona 3.2}

La subzona 3.2 corresponde a la sección de 20 a $0 \mathrm{~cm}$ del sondeo y se caracteriza por: (a) un incremento significativo de la fracción de sedimento fino $(<15 \mu \mathrm{m})$; (b) concentraciones mayores de $\mathrm{Fe}, \mathrm{Mn}, \mathrm{Cu}, \mathrm{Pb}, \mathrm{Zn}, \mathrm{Cr}$ y Co; (c) aumento de la razón caolinita/ilita; y (e) reducción de las concentraciones de $\mathrm{Al}, \mathrm{Ca}, \mathrm{Mg}$ y Ni. Esta sección, que corresponde al periodo subreciente, muestra similitudes con la sección de 90 a $50 \mathrm{~cm}$, con mayor acumulación de sedimentos finos y materia orgánica por la tendencia al aumento del nivel del mar y menor hidrodinámica del área donde se recolectó el sondeo KSGX 40.

\section{Conclusiones}

La presencia de pirita en el sondeo KSGX 40 indica la ocurrencia de periodos de condiciones anóxicas justo debajo de la interfase agua-sedimento y/o dentro de las conchas de foraminíferos. La pirita es un mineral diagenético común en ambientes anóxicos. Se forma por la reacción del ión sulfato con el hierro en su forma reducida $\left(\mathrm{Fe}^{2+}\right)$. Este proceso es mediado por materia orgánica que llega al fondo y luego es oxidada en una secuencia característica de reacciones (Kaplan et al., 1963).

El origen de $\mathrm{Mn}, \mathrm{Cu}, \mathrm{Co}, \mathrm{Fe}, \mathrm{Zn}, \mathrm{Cr}$ y $\mathrm{Pb}$ en los sedimentos está principalmente relacionado con los aportes de detritos continentales y de rocas intemperizadas.

Tomando en cuenta los datos mineralógicos y geoquímicos determinados, la distribución del tamaño de grano y el contenido total de las especies foraminíferas bentónicas, fue posible establecer la zonografía del sondeo KSGX 40. Tal zonografía indica la ocurrencia de algunas oscilaciones climáticas durante el Holoceno que condicionaron el registro sedimentario del depósito lodoso de la plataforma continental de Galicia. 


\section{Conclusions}

The presence of pyrite in core KSGX 40 indicates the occurrence of periods of anoxic conditions just below the sediment-water interface and/or inside foraminifera shells. Pyrite is a diagenetic mineral common in anoxic environments. It is formed by reaction of the sulphate ion with the reduced form of iron $\left(\mathrm{Fe}^{2+}\right)$. This process is mediated by organic matter reaching the sea floor and then being oxidized in a characteristic sequence of reactions (Kaplan et al., 1963).

The origin of $\mathrm{Mn}, \mathrm{Cu}, \mathrm{Co}, \mathrm{Fe}, \mathrm{Zn}, \mathrm{Cr}$ and $\mathrm{Pb}$ in the sediments is mainly related to detrital inputs from continental soils and weathered rocks.

Taking into account the mineralogical and geochemical data determined, the grain size distribution and the total content of benthic foraminifera species, it was possible to establish the zonography of the KSGX 40 core. Such zonography indicates the occurrence of some climatic oscillations during the Holocene that conditioned the sedimentary record of the Galician continental shelf muddy patch.

Climatic oscillations that occurred during the Holocene and oceanic conditions probably related to small sea level oscillations seem to have conditioned the inflow of these sediment types (texture and composition) into the ocean, as well as its redistribution and deposition.

The trace metal content of the sediments in this zone is a consequence not only of natural weathering but also of local influences, reflecting changes in hydrodynamic conditions and deposition of finer particles and organic carbon in sediments and influencing diagenetic changes.

\section{Acknowledgements}

This research was supported by the Industrial Minerals and Clays Research Center of the Foundation for Science and Technology (FCT) and by the University of Aveiro. This project was partly supported by the European Union within the Marine Science and Technology programme (contract MAS3CT97-0076).

\section{References}

Alve, E. and Murray, J.W. (1994). Ecology and taphonomy of benthic foraminifera in a temperate mesotidal inlet. J. Foraminifer. Res., 24(1): 18-27.

Alve, E. and Murray, J.W. (1995). Benthic foraminiferal distribution and abundance changes in Skagerrak surface sediments: 1937 (Höglund) and 1992/1993 data compared. Mar. Micropalaeontol., 25: 269-288.

Araujo, M.F., Jouanneau, J.M., Valério, P., Barbosa, T., Gouveia, A., Weber, O., Oliveira, A., Rodrigues, A. and Dias, J.M.A. (2002). Geochemical tracers of northern Portuguese estuarine sediments on the shelf. Prog. Oceanogr., 52: 277-297.

Banner, F.T., Knight-Jones, E.W. and Wright, J.M. (1994). Protozoa. In: P.J. Hayward and J.S. Ryland (eds.), The Marine Fauna of the British Isles and North-West Europe. Introduction and Protozoans to Arthropods. Oxford Science Publications, pp. 36-50.
Las variaciones climáticas durante el Holoceno y las condiciones oceánicas probablemente relacionadas con oscilaciones pequeñas del nivel del mar parecen haber condicionado la entrada de estos tipos de sedimento (textura y composición) en el océano, así como su redistribución y depósito.

El contenido de metales traza de los sedimentos en esta zona es resultado no sólo del intemperismo natural sino también de influencias locales, reflejando cambios en las condiciones hidrodinámicas y en el depósito de partículas más finas y carbón orgánico en los sedimentos e influenciando cambios diagenéticos.

\section{Agradecimientos}

Esta investigación se realizó con apoyo del Centro de Investigación de Minerales y Arcillas Industriales de la Fundación para Ciencia y Tecnología (FCT) y de la Universidad de Aveiro. Este proyecto fue parcialmente apoyado por la Unión Europea dentro del programa de tecnología y ciencia marina (contrato MAS3-CT97-0076).

Traducido al español por Christine Harris.

Barahona, E. (1974). Arcillas de ladrillería de la provincia de Granada: Evaluación de algunos ensayos de materias primas. Ph.D. thesis, Granada University, Spain, 398 pp.

Bernhard, J.M and Sen Gupta, B.K. (1999). Foraminifera of oxygendepleted environments. In: B.K. Sen Gupta (ed.), Modern Foraminifera. Kluwer Academic Publishers, pp. 201-216.

Blanc-Vernet, L., Pujos, M. and Rosset Moulinier, M. (1984). Les biocénoses de foraminifères benthiques des plateaux continentaux français (Manche, Sud-Gasconhe, Ouest Provence). Benthos’ 83, 2nd International Symposium Benthic Foraminifera (Pau, April 1983). Pau and Bordeaux, pp. 71-79.

Bohncke, S. and Vanderberghe, J. (1991). Small river basins of SNetherlands. In: L. Starkel, K.J. Gregiory and J.B. Thornes (eds.), Fluvial Processes in the Temperate zone during the last 15.000 years. J. Wiley, pp. 253-281.

Brown, A. (1998). Fluvial evidence of the Medieval warm period and the Late Medieval climate deterioration in Europe. In: G. Benito, V. Baker and K. Gregory (eds.), Palaeohydrology and Environmental Change. John Wiley, pp. 43-52.

Buzas, M.A., Culver, S.J. and Jorissen, F.J. (1993). A statistical evaluation of the microhabitats of living (stained) infaunal benthic foraminifera. Mar. Micropalaeontol., 20: 311-320.

Cearreta, A. (1986). Distribution and ecology of benthic foraminifera in the rias of Santoña and San Vicent de la Barquera (Spain). Ph.D. thesis, University of Exeter, 307 pp.

Cearreta, A. (1989). Foraminiferal assemblages in the Ria of San Vicente de la Barquera (Cantabria, Spain). Rev. Esp. Micropaleontol. Madrid, 12(1): 67-80.

Cearreta, A. (1994). Analisis micropaleontológico e interpretación paleoecológica del relleno sedimentario Holoceno en El Estuario del Bidasoa (Golfo de Bizkaia). Geobios, 27(3): 271-283.

Corliss, B.H. (1991). Morphology and microhabitat preferences of benthic foraminifera from the northwest Atlantic Ocean. Mar. Micropalaeontol., 17: 195-236.

Corliss, B.H. and Emerson, S. (1990). Distribution of Rose Bengal stained deep-sea benthic foraminifera from the Nova Scotian 
continental margin and Gulf of Maine. Deep-Sea Res., 37(3A): 381-400.

Cortizas, A.M., Pontevedra-Pombal, X., García-Rodeja, E., NovoaMuñoz, J.C and Shotyk, W. (1999). Mercury in a Spanish peat bog: Archive of climate change and atmospheric metal deposition. Science, 284: 939-942.

Cortizas, A.M., Pérez-Alberti, A., Franco-Maside, S. and GarcíaRodeja, E. (2000). Evolución del paisaje durante el Holoceno en Galicia (NW de la Península Ibérica). In: F. Díaz del Olmo, D. Faust y A.I. Porras (eds.), Environmental Changes during the Holocene. Commission on the Holocene, Universidad de Sevilla, Katolische Universität Eichstätt and AEQA, Sevilla, pp. 61-64.

Crowley, T.J. and North, G.R. (1991). Paleoclimatology. Oxford Monographs on Geology and Geophysics No. 18, 349 pp.

Dias, J., Jouanneau, J., Gonzalez, R., Araújo, M., Drago, T., Garcia, C., Oliveira, A., Rodrigues, A., Vitorino, J. and Weber, O. (2002a). Present day sedimentary processes on the northern Iberian shelf. Prog. Oceanogr., 52(2-4): 249-259.

Dias, J., Gonzalez, R., Garcia, C. and Diaz-del-Rio, V. (2002b). Sediment distribution patterns on the Galicia-Minho continental shelf. Prog. Oceanogr., 52(2-4): 215-231.

Ehlers, J. (1996). Quaternary and Glacial Geology. John Wiley, 578 pp.

Ernst, S.R. (2002). An experimental study on the proxy value of benthic foraminifera. The impact of physical disturbance, oxygen deplection and organic flux. Geologica Ultraiectina, 220: 157 pp.

Fidalgo, L.S. and Vidal-Romani, J.R. (1993). La transgresión Holocene en la Ría de Ares (a Coruña, Galicia, España). Datos cronológicos, sedimentarios y geomorfológicos. Actas 3a Reunião do Quaternário Ibérico, Universidade de Coimbra, pp. 339-345.

Fidalgo, L.S., Bao-Casal, R. and Jalut, G. (1993). Estudio micropaleontológico de una turbera litoral holocena en la Ría de Ares (A Coruña, Espana). Cuaderno Lab. Xeolóxico de Laxe, 18: 54-66.

Frouin, R., Fiuza, A., Ambar, I. and Boyd, T. (1990). Observations of a poleward surface current off the coast of Portugal and Spain during winter. J. Geophys. Res., 95: 679-691.

Grove, J.M. (2001). The Little Ice Age. Routledge, London and York, $498 \mathrm{pp}$.

Jouanneau, J., Garcia, C., Oliveira, A., Rodrigues, A., Dias, J. and Weber, O. (1998). Dispersal and deposition of suspended sediment on the shelf off the Tagus and Sado estuaries, SW Portugal. Prog. Oceanogr., 42: 233-257.

Kaplan, I.R., Emery, K.O. and Rittenber, S.C. (1963) The distribution and isotopic abundance of sulphur. Recent marine sediments off southern California. Geochim. Cosmochim. Acta, 27: 297-335.

Kubler, B. (1964). Les argiles, indicateurs de métamorphisme. Rev. Inst. Français Pétrole, 19: 1093-1112.

Lecomte, P. and Sondag, F. (1980). Regional geochemical reconnaissance in the Belgian Ardennes, secondary dispersion patterns in stream sediments. Mineralium Deposita, 15(1): 47-60.

Levy, A., Mathieu, R., Poignant, A., Rosset-Moulinier, M., Ubaldo, M.L. and Lebreiro, S. (1995). Foraminiferes actuels de la marge continentale Portuguaise-inventaire et distribution. Memórias do Instituto Geológico e Mineiro, Lisboa, 32: 116 pp.

Magri, D. (1997). Middle and late Holocene vegetaion and climate changes in peninsular Italy. In: H.N. Dalfes, G. Kukia and H. Weiss (eds.), Third Millennium BC Climate Change and Old World Collapse. NATO ASI Ser., 149, Springer-Verlag, pp. 517530.

Martins, M.V. and Carapito, M.C. (1999). Distribuição das comunidades bentónicas de foraminíferos na plataforma continental de Aveiro. Comunicações dos Serviços Geológicos de Portugal, 86: 255-278.
Mathieu, R. (1986). Sediments et foraminiferes actuels et ressurgences cotieres sur la marge continentale Atlantique du Maroc. Revue de Paléobiologie, Benthos '86, Spec. No. 2, pp. 845-850.

Mellinger, R.M. (1979). Quantitative X-ray diffraction analysis of clay minerals. An evaluation. Saskatchewan Research Council, Canada, SRC Report G-79: 1-46.

Mendes, I., Gonzalez, R., Lobo, F., Dias, J.M.A. and Martins, V. (2004). Factors influencing the distribution of recent benthic foraminifera on the Guadiana Shelf (southwestern Iberia). Mar. Micropaleontol., 51: 171-192

Moodley, L., Van der Zwaan, G.J., Herman, P.M.J., Kempers, L. and Van Breugel, P. (1997). Differential response of benthic meiofauna to long-term anoxia with special reference to foraminifera (Protista: Sarcodina). Mar. Ecol. Prog. Ser., 158: 151-163.

Moodley, L., Zwaan, G.L., Rutten, G.M.W. Boom, R.C.E. and Kempers, A.J. (1998). Subsurface activity of benthic foraminifera in relation to porewater oxygen content: Laboratory experiments. Mar. Micropaleontol., 34: 91-106.

Mullineaux, L.S and Lohmann, G.P. (1981). Late Quaternary stagnations and recirculation of the eastern Mediterranean: Changes in the deep water recorded by fossil benthic foraminifera. J. Foraminifer. Res., 11(1): 20-39.

Murray, J.W. (1991). Ecology and Palaeoecology of Benthic Foraminifera. Longman Scientific and Technical, London, 397 pp.

Nolting, R.F. and Helder, W. (1991). Lead and zinc as indicators for atmospheric and riverine particle transport to sediments in the Gulf of Lions. Oceanol. Acta, 14(4): 357-367.

Oliveira, A., Rocha, F., Rodrigues, A., Jouanneau, J., Dias, A., Weber, O. and Gomes, C. (2002). Clay minerals from the sedimentary cover from the northwest Iberian shelf. Prog. Oceanogr., 52(2-4): 233-247.

Pascual, A., Weber, O., Rodriguez-Lazaro, J., Jouanneau, J.M. and Pujos, M. (1998). Le comblement de ria de Gernika (Golfe de Gascogne) à l'Holocène terminal. Oceanol. Acta, 21(2): 263-260.

Pevear, D.R. and Mumpton, D.R. (1989). Quantitative mineral analysis of clays. CMS Workshop Lectures, 1 . The Clay Minerals Society, Colorado (USA).

Pujos, M. (1976). Ecologie des foraminiferes benthiques et des thecamoebiens de la Girond et du plateu continental sudGascogne. Application a la connaissance du Quaternaire terminal de la region ouest-Gironde. Thèse Doctorat d' Ètat ès Sciences, Univ. Bordeaux I, Mémoires de l'Institute de Geologie du Bassin D’Aquitaine, Bordeaux, 8, 274 pp.

Rathburn, A.E. and Corliss, B.H. (1994). The ecology of living (stained) deep-sea benthic foraminifera from the Sulu Sea. Paleoceanography, 9(1): 87-150.

Rijk, S., Troelstra, S.R. and Rohling, E.J. (1999). Benthic foraminiferal distribution in the Mediterranean Sea. J. Foraminifer. Res., 20(2): 93-103.

Schultz, L.G. (1964). Quantitative interpretation of mineralogical composition from X-ray and chemical data for the Pierre Shale. US Geol. Surv. Prof. Paper, 391-C: 1-31.

Segonzac, G.D. (1969). Les minéraux argileux dans la diagenèse. Passage au métamorphisme. Mem. Service Carte Géol. AlsaceLorraine, 29, p. 320.

Sen Gupta, B.K. and Machain-Castillo, M.L. (1993). Benthic foraminifera in oxygen-poor habitats. Mar. Micropalaeontol., 20: 183-201.

Shannon, C.E. (1948). The mathematical theory of communication. Bell System Technical J., 27: 379-423; 623-656.

Thorez, J. (1976). Practical Identification of Clay Minerals. G. Lelotte, Belgique. 
Van der Zwaan, G.J. and Jorissen, F.J. (1991). Biofacial patterns in river-induced shelf anoxia. In: R.V. Tyson and T.H. Pearson (eds.), Modern and Ancient Continental Shelf Anoxia. Geol. Soc. London Spec. Publ., 58: 65-82.

Van der Zwaan G.J., Duijnstee, I.A.P., den Dulk M., Ernst, S.R., Jannink, N.T. and Kouwenhoven, T.J. (1999). Benthic foraminifers: Proxies or problems? A review of paleoecological concepts. Earth Sci. Rev., 46: 213-236.

Vergnaud-Grazzini, C., Caralp, M., Faugères, J.C., Gonthier E., Grousset, F.E., Pujol, C. and Saliège, J.F. (1989). Mediterranean outflow through the Strait of Gibraltar since 18,000 years BP. Oceanol. Acta, 12(4): 305-324.
Zazo, C., Goy, J.L., Lario, J. and Silva, P.G. (1996). Littoral zone and rapid climatic changes during the last 20,000 years. The Iberian study case. Z. Geomorph. NF, Suppl. Bd. 102: 119-134.

Zolitschka, B. and Negendank, J.F.W. (1993). Lago Grande di Monticchio (southern Italy): A high resolution sedimentry record of the last 70,000 years. In: J.F.W. Negendank and B. Zolitschka (eds.), Palaeolimnology of European Maar Lakes. Lecture Notes in Earth Sciences. Springer, Heidelberg, 49, pp. 277-288.

Zuo, Z., Eisma, D. and Berger, G.W. (1991). Determination of sediment accumulation and mixing rates in the Gulf of Lions, the Mediterranean Sea. Oceanol. Acta, 14: 253-262. 